\title{
Sínodo 83 sobre la reconciliación: Resonancia de las tesis morales en el aula sinodal
}

El Sínodo parte de la convicción de «que la penitencia y la reconciliación constituyen un punto fundamental del misterio cristiano y una dimensión esencial de la Iglesia...» '. Es consciente de que trata «un tema muy importante y actual en la vida de la Iglesia» ${ }^{2}$, como también de su «urgencia», la cual no debe constituir un impedimento para poder afrontarlo desde una perspectiva mundial, sino un reto a la acción pastoral de la Iglesia ${ }^{3}$.

Proclama abiertamente que sus «proposiciones» «no son ni un documento exhaustivo sobre el tema del Sínodo, ni siquiera un esquema de las diversas intervenciones o sugerencias habidas en el aula sinodal o en las discusiones por grupos. Son un conjunto de indicaciones que los Padres someterán al Papa, como frutordel debate sinodal ${ }^{4}$.

Por mi parte, no pretendo comentar todos y cada uno de los aspectos que aparecen a la simple lectura de las múltiples intervenciones. En este artículo ni siquiera podré extenderme en la presentación de todas las tesis importantes. Sencillamente trataré de ir dejando hablar al mismo Sínodo como respondiendo a muchas de las preguntas, al menos a las más importantes, que más fre-

1. Mons. B. Mve'Engone, Obispo de Oyem (Gabón), 99; Mons. A. Nossol, obispo de Opole (Polonia), 214; Mons. S. Stefano Karlich, relator del Grupo B de lengua hispano-portuguesa, 209. En todas las citas la página se refiere a la obra de G. CONCETTI, Riconciliazione e penitenza nella missione della Chiesa. Documenti ufficiali della sesta asemblea generale del sinodo dei vescovi. Sintesi degli interventi dei Padri, Ediz. Logos, Roma 1983.

2. Mons. M. Dimitrow Stratiew, exarca de Sofía (Bulgaria), 145.

3. Mons. M. J. Conti, obispo de Aberdeen (Escocia), 153; Mons. S. Koto Khoari, obispo de Mohale's Hoek (Lesotho), 159; Mons. A. Lopes Coelho, obispo de Viana do Castelo (Portugal), 149.

4. Card. C. M. Martini, 239. 
cuentemente nos hacemos casi todos cuando pensamos en el sacramento de la reconciliación.

\section{CRISIS DEL SACRAMENTO DE LA RECONCILIACIÓN}

El Sínodo no ha considerado necesario discutir la existencia o no de una crisis en la práctica del sacramento de la reconciliación. La admite como un hecho constatado. En ello coincide la experiencia de la mayor parte, casi de la totalidad de los participantes, venidos de las diversas partes del mundo. Hablan de una «disminución según los datos estadísticos» ${ }^{5}$, «vistosa» ${ }^{6}$, «drástica» ${ }^{7}$, que impresiona ${ }^{8}, \mathrm{y}$ aparecida misteriosa e improvisamente ${ }^{9}$. No es posible negar una desafección generalizada hacia este sacramento ${ }^{10}$, que atenaza a las «élites de los cristianos y a los jóvenes» ${ }^{11}$, que hace que hasta los religiosos y el clero lo celebren raramente ${ }^{12}$, y que ha permitido, a algunos cristianos, pensar que este sacramento había sido abolido ${ }^{13}$. Consecuentemente esta

5. Card. Juan Landázuri Ricketts, arzobispo de Lima, 74; Mons. P. Verschuren, obispo de Helsinki, 80; Mons. J. Wanke, administrador apostólico de Erfurt-Meiningen (Berlín), 88; Mons. A. B. Vaugghan, obispo auxiliar de New York, 105; Mons. B. J. Wallace, obispo de Rockhamptor (Australia), 156; Mons. M. L. Romero, obispo de Ciudad Guayana (Venezuela), 180; Mons. M. Maître, obispo de Bambari (república Centroafricana), 188. El documento final de la Comisión Teológica Internacional de 1982 dice: «La penitencia, tal como se ha practicado frecuentemente en los últimos tiempos de la Iglesia, es considerada por muchos cristianos como vacía e ineficaz); Mons. H. J. Spital, obispo de Trier (República Federal de Alemania), 177.

6. Mons. J. de Jesús Pimiento Rodríguez, arzobispo de Manizales (Colombia), 93.

7. Mons. J. de Jesús Pimiento Rodríguez, 1. c.; Mons. A. Exner, arzobispo de Winnipeg (Canadá), 96; Mons. P. J. Cordes, vice-presidente del Pontificio Consejo para los Laicos, 158; Mons. P. R. Bello, obispo de Los Teques (Venezuela), 159.

8. Card. C. M. Martini, 192.

9. Mons. E. C. Szoka, arzobispo de Detroit (USA), 145.

10. Mons. J. Vilnet, obispo de Lille (Francia), 76; Mons. P. Verschuren, obispo de Helsinki, 80; Mons. G. Sinhla, obispo de Owando (Congo), 147; Mons. P. Fanoko, obispo de Atakpamé (Togo), 162; Card. A. P. Khoraiche, patriarca de Antioquía de los Maronitas, 174.

11. Mons. J. Babatunde Adelakun, obispo de Oyo (Nigeria), 82: «Condividimos nuestra alegría porque en muchas diócesis de Nigeria un gran número de fieles recibe la gracia de este sacramento. Pero también condividimos nuestra preocupación porque muchos jóvenes y la élite rechazan este sacramento». Lamentan que la tradicional enumeración de los pecados, tal como la han aprendido en el catecismo, no les dice nada. Afirman que no aciertan a ver en el confesor un padre con el que puedan discutir sus problemas y capaz de considerar sus pecados en el contexto de su vida.

«Nos encontramos, pues, frente a dos problemas: Un gran número de penitentes con pocos confesores y los jóvenes y la élite que lo rehúyen».

12. Mons. S. E. Carter, arzobispo de Kigston (Jamaica), 67.

13. Mons. M. L. Romero, obispo de Ciudad Guayana (Venezuela), 180: «Asistimos en nuestro país a una disminución del sentido del pecado y de la práctica del sacramento de la penitencia, en parte debida a la opinión, difundida entre los fieles, de que este sacramento ha sido 
crisis es considerada «seria» ${ }^{14}$, tanto que algunos de los participantes, quizás llevados de su pesimismo, vislumbran pocas esperanzas de éxito ${ }^{15}$. Las palabras del cardenal Francisek Macharski, arzobispo de Krakòw (Polonia) pudieran ser una respuesta a tal desaliento: «No obstante las varias y constantes imperfecciones que se dan en la administración del sacramento, debemos subrayar que la Iglesia no puede darse por vencida en las actuales dificultades, cooperando de alguna manera a la desaparción de la confesión individual» ${ }^{16}$, que debe s'rr mantenida ${ }^{17}$.

\section{Causas desencadenantes o mantenedoras de la crisis}

Resulta prácticamente imposible enumerar todos y cada uno de los elementos que los Padres sinodales relacionan con la crisis. Me limitaré a enumerar únicamente aquellos que más llaman la atención de quienes leen reposadamente las intervenciones sinodales.

\section{Un cierto doscuido de la conversión interior, elemento fundamental en la celebración del sacramento}

«La confesión no sustituye a la conversión. La exigencia fundamental de Cristo es la conversión del corazón y de la vida. El sacramento de la reconciliación es su signo y expresión. Se corre el riesgo de considerar la confesión como un sustituto de la conversión y de que no se tome en serio la decisión de comenzar una vida nueva. Consiguientemente se subrayará en primer lugar la importancia del compromiso personal radical con un futuro nuevo y sus pruebas concretas. El acentuar el sentido de la confesión como servicio a la conver-

abolidó y en parte, a la negligencia de los sacerdotes en administrarlo, por considerar que las confesiones son un hecho habitudinario y no representan una verdadera conversión».

14. S.B.R.G.G. Beltratti, patriarca latino de Jerusalen, 69; Mons. T. Tschibangu Thsishi$k u$, obispo auxiliar de Kinshasa (Zaire), 83; Mons. H. J. Spital, obispo de Trier (República Federal de Alemania), 108; Mons. J. B. Möller, obispo de Groningen (Holanda), 111; Mons. O. Wüst, obispo de Basilea, 120; Mons. F. S. Aguilar, obispo de León, 121; Mons. R. Stecher, obispo de Innsbruck, 123; Mons. G. Prata, arzobispo de Cochabamba (Bolivia), 137; Mons. L. L. Alvarado, obispo de Guacho (Perú), 146; Mons. Ph. Kourouma, obispo de N'Zérékoré (Guinea), 150; Mons. M. J. Conti, obispo de Aberdeen (Escocia), 153; Mons. O. Rodríguez Madariaga, administrador apostólico de Santa Rosa de Copán (Honduras), 160; Grupo A de lengua iglesia, 194-5; Mons. E. Stefano, relator del Grupo B de lengua española y portuguesa, 208.

15. Mons. S. Koto Khoari, obispo de Mohalés Hoek Lesotho), 159: «La Conferencia episcopal del Lesotho cree que frecuentemente se da la impresión de que la reconciliación es tan difícil que existen pocas esperanzas de suceso, porque se olvida que la reconciliación es un don de Dios, que es omnipotente».

16. Card. F. Macharski, arzobispo de Kraków (Polonia), 75.

17. Card. J. L. Sin, arzobispo de Manila (Filipinas), 68. 
sión tiene también un significado antropológico y ecuménico ...Toda la vida de los cristianos y de la Iglesia debe ser un constante camino de conversión, que jamás termina y que es absolutamente insustituible» ${ }^{18}$. "La práctica de la confesión no ha ido acompañada con frecuencia tan considerable de la conversión interior...» ${ }^{19}$.

2. Olvido del aspecto comunitario y eclesial del sacramento o del anticomunitario y antieclesial del pecado

«En la confesión auricular aparece más claramente el aspecto personal del encuentro entre el penitente y el ministro del sacramento, que puede ayudar de modo más inmediato a una auténtica conversión - lo cual muchas veces no ha sucedido ni sucede- pero queda muy en la sombra el aspecto eclesial y comunitario del sacramento de la penitencia» ${ }^{20}$.

Por otra parte «la excesiva importancia dada al pecado llamado estructural, como si fuese únicamente signo y consecuencia de las estructuras sociales injustas y no echara sus raíces en el corazón del hombre...» ${ }^{21}$, relega a segundo plano la relación con Dios, la reconciliación personal e interior, es decir, la liberación del pecado, raíz del mal moral con sus consecuencias humanas y sociales» ${ }^{22}$.

\section{La incomprensión del significado de la acción eclesial en el sacramento}

«Nuestra gente sufre una visión bidimensional de la religión y de la vida interior, que se para de manera, a veces narcisística, en su relación individual con Dios, sin valorar suficientemente el carácter de mediación y sacramental de la Iglesia ni el papel que Dios ha querido asignar a los sacramentos» ${ }^{23}$.

«En medio de la actual crisis del sacramento de la reconciliación algunos querrían prescindir, en sus prácticas de reconciliación, de cualquier ministerio de mediación. Nos confesamos sólo con Dios, se dice» ${ }^{24}$.

Se olvida que «la alianza entre Dios y el hombre no se encarna nada más que a través de las mediaciones concretas: mediación de palabras y de ritos, .mediación de personas encargadas de transmitir estas palabras y ayudar a vi -

18. Mons. A. Sustar, arzobispo de Lubiana (Jugoslacia), 115.

19. Mons. A. Lorscheider, arzobispo de Fortaleza (Brasil), 183; Card. J. L. Sin, arzobispo de Manila, 68; Mons. B. Mve'Engone, obispo de Oyem (Gabón), 99.

20. Card. A. Lorscheider, 183.

21. Mons. J. Freire Falcáo, arzobispo de Teresina (Brasil), 73.

22. Card. B. Gantin, 74.

23. Card. J. L. Bernardin, arzobispo de Chicago (USA), 71-72.

24. Mons. Ph. Kourouma, obispo de N'Zérékoré (Guinea), 150. 
vir esos ritos. El ministerio de la reconciliación le ha sido encomendado a la Iglesia entera: Ella es, en Cristo Jesús, el signo sacramental de salvación para el mundo. $Y$ sólo será tal signo sacramental si sus miembros, que siguen siendo pecadores, reciben el perdón de Dios a través de la mediación de los hermanos, como portadores de ese perdón» ${ }^{25}$.

Los Padres sinodales parten de la tesis que presenta a la Iglesia como sacramento y signo creíble de reconciliación ${ }^{26}$, pero no pueden olvidar que «cuando se habla de signos nos estamos refiriendo a algo que la gente ve, algo de lo que se tiene experiencia y muchos no perciben (experimentan) a la Iglesia tal y como ella misma se describe» ${ }^{27}$, porque de hecho la Iglesia no logra vivir y manifestar más que imperfectamente el ideal que ella se propone ${ }^{28}$.

\section{Poca atención prestada a la cultura actual}

«La cultura es valorada no solamente como expresión de la subjetividad y causalidad humanas, sino también como reflejo de las actitudes del hombre frente al pecado, a la penitencia y a la reconciliación; y hasta como un elemento que condiciona al hombre más que las mismas estructuras sociales» ${ }^{29}$.

La cultura ofrece muchos valores positivos que la catequesis debería asimilar hasta el punto de convertirlos en instrumentos a servicio de la transmisión de la vivencia cristiana, pero también da vida a ciertos «principios y valores que obstaculizan la conversión, la penitencia y la reconciliación» ${ }^{30}$. Algunas intervenciones sinodales se paran en la descripción de tales aspectos negativos de la cultura. Ella ha creado «un ambiente paganizante, acentuado por el

25. Mons. F. Favreau, obispo de Nanterre (Francia), 179-180.

26. Mons. P. J. Cullinare, obispo de Pamerston North (Nueva Zelanda), 72; Mons. J. Vilnet, obispo de Lille (Francia), 76.

27. Mons. P. J. Cullinam, 72.

28. Mons. J. Vilnet, 76.

29. Mons. J. Freire Falcão, obispo de Teresina (Brasil), 72-3.

30. Mons. J. Spaita, obispo de Mansa (Zambia), 98; Mons. H. S. D'Souza, arzobispo de Cuttack-Bhubaneswar (India), 133: «Asia es víctima del pecado «estructural». Asia es un continente rico, pero con una población pobre. El colonialismo ha cambiado hacia peor sus modelos económicos. Hoy están en acción otras fuerzas que tienen el continente en una situación de explotación. El sistema comercial mundial, el militarismo, las multinacionales, la política internacional de las bancas están llevando a Asia a la pobreza».

«La respuesta cristiana del pasado era la ayuda y la caridad, sobre todo en momentos de calamidad».

«Se impone una nueva exigencia de sensibilizar las conciencias con las graves consecuencias de las injusticias nacidas de las estructuras. Los obispos han dado ejemplo hablando claramente contra las armas nucleares. Los obispos alemanes han pedido prácticas comerciales más justas a la UNCTAD. Los obispos indios trabajan por la igualdad de la gente, comprometiéndose contra la discriminación de las castas y la subordinación de la mujer». 
laicismo imperante» y es causa de «la pérdida de los valores fundamentales de la vida, de un debilitamiento del sentido y de la noción misma de pecado»; valora excesivamente el pecado colectivo, del que culpa a las estructuras sociales, con detrimento de la responsabilidad personal...» ${ }^{31}$; hablan de una «filosofía hedonista» ${ }^{32}$, de un "humanismo ateo» ${ }^{33}$ y de un "ateísmo práctico» con una pérdida del sentido de Dios, del misterio, de la santidad y de la importancia de Dios en la vida ${ }^{34}$, por lo cual el «ateísmo contemporáneo es un desafío gigantesco a la misión reconciliadora de la Iglesia ${ }^{35}$.

La crisis del sacramento de la reconciliación se enmarca en el amplio cuadro de la crisis de la Iglesia y del mundo, que padece las consecuencias del «se-

31. Card. J. Landázuri Riketts, 74: «Las causas de la crisis de la confesión son múltiples, entre otras: El ambiente paganizante; el acentuado laicismo imperante; la pérdida de los valores fundamentales de la vida; el debilitamiento del sentido y de la noción misma del pecado; la menor disponibilidad de algunos sacerdotes en cuanto a la administración del sacramento; la nociva influencia entre los fieles, principalmente entre los jóvenes, de ciertas corrientes teológicas que disminuyen y prácticamente ignoran el pecado personal, acentuando de manera excesiva el pecado colectivo de las estructuras sociales; la pretensión de querer sustituir las confesiones sacramentales con la absolución colectiva, etc.»; Card. A. López Trujillo, arzobispo de Medellín (Colombia), 82; Mons. D. J. Ryan, obispo de Dublín, 91.

32. Mons. M. Hermaniuk, arzobispo metropolita de Winnipeg de los Ucranianos, 86: «La noción de pecado está profundamente falseada en muchos cristianos como consecuencia de un «ateísmo humanista» que, negando la existencia de Dios, convierte al hombre en el dueño supremo de sus propios destinos, en el único legislador en el campo del bien y del mal, en el juez único de las propias acciones. Dominados por esta filosofía hedonística pagana, muchos contemporáneos aceptan como bien lo que les agrada y rechazan lo que les desagrada y aceptan así el placer como criterio último de la vida humana...».

33. Mons. M. Hermaniuk, 86; P. E. Viganò, rector mayor de la Sociedad Salesiana de S. Juan Bosco, 78; Card. P. Zoungrana, arzobispo de Ouagagougou (Alto Volta), 80-81: «Se nos plantean tres interrogantes: 1) ¿Anunciamos la justicia y la caridad en completa sintonía con el Evangelio, con todas las exigencias del mensaje de Cristo, particularmente las de la caridad cristiana, en medio de un mundo materialístico?; El pueblo de Dios espera una exposición clara, sólida y segura del Evangelio en medio de este mundo laicizado y angustiado. Para ellos se necesita una perfecta solidaridad entre los Pastores en la enseñanza de la doctrina. ¿Qué hacemos?; 3) ¿Cuál es la parte de responsabilidad que nos toca en la disminución del sentido del pecado y de la penitencia entre los fieles? En este aspecto, ¿cuál es el efecto del testimonio de nuestra vida personal?».

34. Mons. A. Exner, arzobispo de Winnipeg (Canadá), 96.

35. Mons. L. A. Vachon, arzobispo de Québec (Canadá), 174-5: «El ateísmo constituye un desafío gigantesco a la misión reconciliadora de la Iglesia. Ella, guiada por el Espíritu de Pentecostés, es invitada al diálogo con la incredulidad, díalogo que ha de conducir según las condiciones de todo diálogo: escucha, predisposición positiva hacia los valores del otro y búsqueda común de posibilidades de reconciliación».

«La Iglesia debería revitalizar una cultura de la fe. Para ello debería promover los valores del humanismo cristiano tanto en la existencia personal como en la colectiva, partiendo de los valores humanos y seculares, cuando fuere posible: respeto de la vida del otro, justicia, solidaridad, fraternidad, búsqueda de la verdad, desarrollo personal integral, cualidad de vida familiar, etc. En estos campos se exigen elecciones de valores y es posible la colaboración de cristianos y no cristianos. Si la Iglesia cree en el hombre y en la mujer, éstos, a su vez, pueden creer en la Iglesia». 
cularismo, de la excesiva autonomía, inseguridad y confusión doctrinal, del abandono por parte de los sacerdotes del ministerio de la reconciliación sacramental» ${ }^{36}$. Las consecuencias de todo esto son «muchas actitudes de nuestros contemporáneos contrarias a la virtud de la penitencia, como «una ética de la autosuficiencia que evidencia solamente la realización personal, una tendencia a la privatización de la religión, la negación de valores morales absolutos y la ignorancia de las estructuras y de la disciplina religiosa en la búsqueda de significados espirituales» ${ }^{37}$.

\section{La carencia de pensamiento sobre el «carácter histórico del pecado»}

«La reflexión sistemática sobre «el carácter histórico del pecado sería un buen punto de partida para una teología sobre las estructuras sociales de pecado» ${ }^{38}$, puesto que «se da una estrecha conexión entre el ministerio sacramental de la penitencia y la sanción de las situaciones sociales de división entre los hombres. La importancia del sacramento de la penitencia brillará en toda su plenitud, sólo cuando se perciba con claridad dicha relación. Quizás ésta sea una de las causas de la disminución de la frecuencia de la confesión» ${ }^{3 \phi}$.

También se habla de la falta de un desarrollo adecuado de la concepción dinámica del pecado y del no reconocimiento de la importancia de la teoría de la opción fundamental ${ }^{40}$.

\section{La pérdida del sentido del pecado personal}

La disminución del sentido del pecado es uno de los hechos que el Sínodo admite sin discusiones. Frecuentes intervenciones lo subrayan ${ }^{41}$. Algunos advierten que se trata de un proceso dinámico que va agravándose progresivamente ${ }^{42}$, pasando por una relativización del sentido del pecado ${ }^{43}$, por un fal-

36. Mons. S. Stefano Karlich, 208.

37. Mons. J. L. Bernardin, arzobispo de Chicago (USA), 171.

38. Mons. A. Fernández, arzobispo de Delhi (India), 73: «Tal perspectiva considera el pecado en su carácter histórico, lo cual constituye un buen punto de partida para una teología de las estructuras sociales de pecado. El sínodo debe hacer conocer estas estructuras e invitar proféticamente a lograr su retorno a los amorosos designios de Dios para la humanidad».

39. Card. C. M. Martini, 64.

40. Mons. J. M. Santos Ascarza, arzobispo de Concepción (Chile), 86: «Hemos de presentar, en unidad de fe y de vida, la Buena Nueva. El esquema presenta en pocas páginas una síntesis notable de los principales problemas de la teología moral, con una concepción dinámica del pecado y reconoce la importancia de la opción fundamental...».

41. Mons. A. Exner, arzobispo de Winnipeg (Canadá), 96; Mons. A. Quarracino, obispo de Avellaneda (Argentina), 96-97; Mons. M. Magrassi, arzobispo de Bari (Italia), 104.

42. Mons. C. A. Nicolini, administrador apostólico de Salto (Uruguay), 66; Card. J. Landázuri Riketts, 74; Mons. J. Vilnet, obispo de Lille (Francia), 76; Mons. P. Verschuren, obispo de Helsinki, 80; Card. A. Loscheider, 81; Mons. A. Zumárraga, arzobispo auxiliar de Quito, 95; Mons. $V$. Mensah, obispo de Porto Novo (Benín), 126.

43. Mons. Mons. T. Ushibangu, obispo auxiliar de Kinshasa (Zaire), 83: «Relativización 
seamiento del mismo ${ }^{44}$, de forma que estamos viviendo una verdadera crisis de la conciencia del pecado ${ }^{45}$, que parece conducirnos a la pérdida del sentido del mal y hasta del mismo sentido moral ${ }^{46}$. Es significativa la conclusión a la que llega el grupo $\mathrm{C}$ de lengua francesa: «Se han propuesto orientaciones para formar a los futuros sacerdotes en el sentido profundo del pecado y en la estima del sacramento de la reconciliación ${ }^{47}$. Como si reconocieran que 'una cultura que rezuma humanismo ateo y sin verdadero sentido del pecado' está demostrándose más fuerte que la misma vivencia cristiana» ${ }^{48}$.

Mons. Samuel E. Carter, arzobispo de Kingston (Jamaica) califica de inadecuado el atribuir la crisis del sacramento de la reconciliación a la pérdida del sentido del pecado, puesto que tampoco lo frecuentan las personas piadosas, ni siquiera el clero y los religiosos ${ }^{49}$. No obstante la mayor parte de los Padres sinodales admiten como hecho no discutible la pérdida o, al menos, el debilitarse del verdadero concepto del pecado "como rechace del amor de Dios, como una división del hombre en sí mismo y como un alejamiento del prójimo» ${ }^{50}$. «Muchos obispos de Estados Unidos sostienen que el declinar de

del sentido del pecado, entre otras cosas por la insuficiente explicación del espíritu de algunas reformas derivadas de los principios del Concilio».

«Los intelectuales africanos, al igual que otros, sufren el influjo de la crítica que hacen las ciencias humanas: antropología, sociología, psicología... que no siempre ha recibido una respuesta adecuada».

«Una causa global a nivel de cultura general: existe una desconexión entre el sistema cristiano de la penitencia y el del pueblo africano en cuanto a la concepción general del error y del pecado...».

44. Mons. M. Hermaniuk, 86.

45. Mons. L. L. Alvarado, obispo de Huacho (Perú), 146.

46. Card. A. P. Khraiche, patriarca de Antioquía de los Melquitas, 168: «El hombre «moderno" y "secularizado» es alérgico a toda referencia a un ser superior al que deba responder de su propia conducta. Se constata la ausencia de todo sentido moral, sin remordimiento; todo acto encuentra justificación en sí mismo; el fin justifica los medios; relativización según tiempos y lugares. Esto aleja mucho de la enseñanza del Vaticano II (G.S. n. 71)... ¿Cómo conservar la rectitud y capacidad de discernimiento de la conciencia?...»; Mons. V. Mensah, obispo de Porto Novo (Benín), 126; Mons. G. Singha, obispo de Owando (Congo), 127; Mons. O. Páez Garcete, obispo de S. Pedro (Paraguay), 160; Mons. O. Rodríguez Madariaga, administrador apostólico de Santa Rosa de Copán (Honduras), 160; Mons. M. Maître, obispo de Bambari (República Centroafricana), 188; Mons. A. Zumárraga, arzobispo auxiliar de Quito, 95.

47. Mons. S. Stefano Karlich, relator del Grupo C de lengua francesa, 207.

48. P. E. Viganó, 78.

49. Mons. S. E. Carter, 67.

50. Mons. M. Hermaniuk, 86; Mons. Ch. Vandame, arzobispo de N'Djamena (Ciad), 136: «Algunos cristianos confunden las representaciones tradicionales con las representaciones cristianas del pecado, por ej. confusión entre prohibición y pecado»; Mons. N. J. López Rodríguez, arzobispo de Santo Domingo (Rep. Dominicana), 136: «La Conferencia Episcopal Dominicana sugiere que el Sínodo explique claramente las relaciones del hombre con Dios, con los demás y con la naturaleza; que defina con precisión los conceptos de penitencia, reconciliación, redención, sal- 
la frecuencia del sacramento de la reconciliación depende en parte de la confusión sobre cuál es el constitutivo del pecado grave, sobre qué pecados deben confesarse y sobre si el pecado mortal es una cosa muy rara» ${ }^{51}$. "La crisis de la penitencia, dice monseñor Lorenzo León Álvarado, obispo de Huacho (Perú), va estrechamente ligada a la crisis de la concencia del pecado» ${ }^{52}$.

Más bien las preocupaciones de los Padres sinodales giran en torno a las causas de la pérdida del sentido del pecado y sus posibles soluciones. Por lo que se refiere a las causas hablan de la «pérdida de relación con Dios» ${ }^{53}$, de «la crisis del sentido de Dios, de la experiencia y del modo de vivir de Dios» ${ }^{54}$, de «la crisis de fe, del sentido de lo sagrado y de la oración» ${ }^{55}$, de «la pérdida del sentido de la transcendencia» ${ }^{56}$, de manera que, fenomenológicamente, el pecado del mundo contemporáneo presenta las connotaciones de la noaceptación, de la diversidad, del rechazo ideológico de Dios y de la perversión de la verdad» ${ }^{57}$.

También «la injusticia social hace perder el sentido del pecado en algunos países. Los ricos se han habituado a' la injusticia como si no fuera pecado,

vación y regeneración e insista sobre la necesidad de una acertada catequesis sobre el sacramento de la reconciliación»; Mons. T. Tshibangu, obispo auxiliar de Kinshasa (Zaire), 83-84; Mons. A. M. Deskur, 94-5.

51. Mons. A. B. Vaughan, obispo auxiliar de New York, 105-6.

52. Mons. L. L. Alvarado, obispo de Huacho (Perú), 146.

53. Mons. J. G. Calderón, obispo de Cartagena (Colombia), 85; Mons. G. Zubeir Wako, arzobispo de Khartum (Sudán), 187: «Hemos atribuido la causa de la disminución de la celebración y de la práctica de la penitencia a la pédida del sentido del pecado y de Dios».

«A mi me parece que la causa es más bien la disminución de la fe y de la esperanza que, a su vez, causa inseguridad y desconfianza. La S. Escritura nos enseña que el pueblo de Israel abandonaba a su Dios, siempre que pensaba haber encontrado la fidelidad y la seguridad en otro. Ello le conducía a la miseria y a la desesperación. Los profetas lograban reconducirlos a Dios, recordándoles las promesas de Dios y su fidelidad a las promesas. La Iglesia necesita proclamar de manera más incisiva, como misión profética, «la fidelidad de Dios a sus promesas». El Sínodo debería considerar su misión la de encontrar los medios más eficaces posibles para restituir al hombre de hoy su fe en las cosas que esperamos y en las cosas que no podemos ver»; Mons. A. Jakab, obispo de Alba Julia (Romania), 98.

54. Mons. L. L. Alvarado, obispo de Huacho (Perú), 146.

55. Mons. F. Franić, arzobispo de Split-Makarska (Jugoslavia), 90-91.

56. Mons. A. Quarracino, obispo de Avellaneda (Argentina), 96-7: «Con la pédida del sentido de la transcendencia el hombre ha perdido también el sentido del pecado y se ha convertido, conscientemente o no, en un objeto de la manipulación de la técnica, de los mass-media, de las fuerzas políticas y económicas para las cuales no existe moral alguna. Se vive en un clima general de pesimismo y de terror. Podríamos decir que esta pérdida se refleja también en el seno de la Iglesia, ya que apenas se tratan ciertos temas, como la salvación eterna, el pecado, la gracia, la inhabitación trinitaria y la llamada universal a la santidad...»; Mons. V. Mensaj, obispo de Porto Novo (Benín) 126.

57. Card. G. Danneels, 204; Mons. M. J. Conti, obispo de Alberdeen (Escocia), 154. 
mientras que los pobres consideran que el odio contra los ricos es una cosa buena» ${ }^{58}$.

No quisiera silenciar los perniciosos efectos de la colectivización de la conciencia que «obstaculiza claramente la capacidad de diferenciar y discernir las esferas inconfundibles de lo propio y de lo del otro, de lo personal y de lo social. La raíz del mal se encuentra en la huida del hombre de sí mismo, en el vacío de su vida interior... Cuando se atenúan los contornos, la responsabilidad personal disminuye o crece solamente por breve tiempo. Esta atenuación de la conciencia moral, fruto de la colectivización, lleva al hombre a configurar las normas de la propia conciencia según los juicios y opiniones del ambiente y de la mayoría, conduce a jugar con la conciencia personal de cada momento. Este abandono de las instancias personales de la moral aumenta si no se tiene la experiencia de un «yo» amado y reconciliado con el «Yo» divino, que se hace «Emmanuel»: Dios con nosotros.

«La huida del hombre de sí mismo da lugar a una especie de «culpa» velada o a un vago sentimiento de desesperación que periódicamente aflora y que cierra las puertas a una verdadera reconciliación» ${ }^{59}$.

\section{Falta de claridad o confusión en el concepto de pecado}

No pocos moralistas se verán identificados plenamente con los trazos descriptivos con que los Padres describen su insatisfacción sobre los diversos capítulos relativos a la doctrina sobre el pecado. Gracias a las manifestaciones sinodales los estudiosos de la moral fortificarán el sentido del sano espíritu pastoral que les mueve en todas sus discusiones y esfuerzos por abrir caminos nuevos que nos ayuden a captar un poco mejor la terrible realidad del pecado.

Son muchas las intervenciones sinodales que, de una manera u otra, traslucen su identificación con la denuncia planteada por Mons. José Delicado Baeza, arzobispo de Valladolid: Existe una «confusión en el concepto divergente» del pecado «también en el interior de la comunidad eclesial» ${ }^{60}$. Confusión «entre las representaciones cristianas y las representaciones tradicionales del pecado, confusión, por ejemplo, entre prohibición y pecado» ${ }^{61}$. Una confusión que, contemplada en su profundidad, gira en torno «al verdadero constitutivo del pecado grave, en torno a los pecados que deben ser confesados» $\mathrm{y}$ en torno al fundamental problema de «si el pecado mortal es o no cosa muy rara» en la vida $\mathrm{d}$ hombre ${ }^{62}$.

\footnotetext{
58. Mons. J. G. Calderón, obispo de Cartagena (Colombia), 85.

59. Mons. C. A. Nicolini, administrador apostólico de Salto (Uruguay), 66-67.

60. Mons. J. Delicado Baeza, arzobispo de Valladolid, 134.

61. Mons. Ch. Vandame, arzobispo de N'Djamena (Ciad), 136.

62. Mons. A. B. Vaughan, obispo auxiliar de New York, 105.
} 
«Algunas de estas dificultades provienen de la contestación hecha a la enseñanza oficial que está cuasando graves problemas cuando toca a las normas prácticas» ${ }^{63}$. Una contestación que Mons.Antonio Troyo Calderón Contreras, obispo auxiliar de San José de Costa Rica, describe con frases duras: «La falta de verdad guía a ciertas corrientes teológicas marcadas por la alergia y oposición al Magisterio, las hace presentar como tesis del Magisterio hipótesis discutibles y convertir en hipótesis discutibles tesis del Magisterio y hasta se dejan orientar por metodologías ideológicas que desembocan en concepciones abiertamente marxistas. Las conduce a relecturas del Evangelio, a opciones pastorales socio-políticas, al recurso a la violencia como opción preferencial por los pobres, a la participación directa en la guerrilla y el terrorismo; al reforzamiento, con todas las consecuencias, de la que es llamada erróneamente «iglesia popular». Añádese que algunos de estos mantienen «la actitud tenaz de lleṿar estas ideas a los centros de formación, no solamente de laicos, sino preferentemente de sacerdotes y religiosos» ${ }^{64}$. Ni es menos radical el card. Juan Landázuri Rikets, arzobispo de Lima, cuando, entre las causas de la disminución de la frecuencia de la confesión, enumera «ciertas corrientes teológicas que disminuyen y prácticamente ignoran el pecado personal, acentuando de forma exagerada el pecado colectivo de las estructuras sociales y pretenden sustituir la confesión sacramental (individual) con la absolución general» ${ }^{65}$.

Claro que, gracias a Dios, no todos los Padres sinodales suscriben tales denuncias o, al menos, no todos las admiten con tanta radicalidad. Sin volver sobre las causas de la disminución del sentido del pecado, bástenos recordar otra línea.

Admitido este «concepto divergente del pecado existente también en el interior de la comunidad eclesial», se comprende que el Sínodo pida insistentemente «una perfecta solidaridad en la enseñanza de la doctrina» ${ }^{66}$, «una predicación unívoca plena del concepto de pecado, teniendo en cuenta la conciencia eclesial» ${ }^{67}$.

63. Mons. A. B. Vaughan, 105.

64. Mons. A. Troyo Calderón, 121-122.

65. Card. Landázuri Ricketts, 74; Rev. P. M. Boyle, 102: «Uno de los grandes sufrimientos de la Iglesia actual es que muchos de sus hijos no aceptan la enseñanza y la legislación eclesiástica en algunos sectores de la vida. Esta desobediencia es incompatible con el verdadero espíritu de penitencia y de reconciliación. Los religiosos, como signo de unidad y reconciliación, deberían sobresalir en el ejemplo de obediencia a la legislación y a la enseñanza eclesiástica».

66. Card. P. Zoungrana, arzobispo de Ouagadougou (Alto Volta), 80.

67. Mons. J. Delicado Baeza, arzobispo de Valladolid, 134; Mons. F. Francić, arzobispo de Split-Makarska (Jugoslavia), 90: «Aclárese el papel de los obispos, sacerdotes y teólogos en las obras de reconciliación y penitencia, dando prioridad al magisterio auténtico de los obispos, unidos en comunidad de verdadera fe con el Sumo Pontífice»; Mons. A. Quarracino, obispo de Avellaneda (Argentina), 97: «Una Iglesia «reconciliadora» debe ser una Iglesia «reconciliada» en sí 
Claro que si para algunos sinodales «solidaridad» significara volver la mirada hacia el pasado para re-proponer e imponer sus esquemas mentales, el grupo A de lengua inglesa advierte que «los modos tradicionales de predicación sobre el pecado, la virtud y la ley no han cosechado grandes frutos porque parecían alejados de las aspiraciones humanas... Por lo cual la catequesis clara sobre el pecado, la conciencia y la conversión no pueden consistir en el retorno a las nociones y a las categorías simplicistas del pecado» ${ }^{68}$. Admitida la ineficacia actual de una catequesis y de unas exposiciones que en otro tiempo dieron su fruto, se alzan voces sinodales que, sin titubeos, consideran un «deber» del Sínodo «estimular una pastoral que comporte una clarificación doctrinal sobre el pecado y sus consecuencias sociales» ${ }^{69}$, hacer todo lo posible por restablecer en los fieles la verdadera noción de pecado, profundamente falseada hoy en muchos de ellos ${ }^{70}$, ofrecer «una nueva definición del pecado según la Sagrada Escritura y en conformidad con nuestro tiempo, precisando, particularmente, la naturaleza del pecado grave» ${ }^{71}$, «reformular la definición

misma. Por eso es preciso recordar algunos elementos, entre otros: la caridad, como ley fundamental, y la plena adhesión al Santo Padre...»; Mons. M. Revollo, Bravo, arzobispo de Nueva Pamplona (Colombia), 142: «La unidad eclesial y la sincera obediencia al Magisterio con la mejor garantía de encontrar la verdad tanto en la investigación teológica como en la acción pastoral...».

68. Mons. P. G. Cullinane, relator del Grupo A de lengua inglesa, 195; Mons. H. S. Spital, obispo de Triel (Rep. Fed. de Alemania), 177: «Si un cristiano se preocupa de la acusación completa más que de arrepentirse, está privilegiando el aspecto jurídico. Y cae en un ritualismo equivocado, quien se limita solamente a buscar las fórmulas «en las listas de pecados» y no reflexiona sinceramente sobre su comportamiento pecaminoso...»; Mons. R. Stecher, obispo de Innsbruck (Austria), 122-123: «...hemos de reconocer que el rigorismo perdurante en ciertos aspectos de la llamada teología moral no está libre de culpa en lo tocante a la actual y deplorable confusión de las conciencias. El desconsiderado y frecuente uso de la palabra «sub gravi», que era empleada en el sentido «de obligatorio bajo pena de pecado mortal», nos ha dejado como consecuencia la multiplicación de los pecados graves «objetivos». Resultados semejantes ha tenido también la enseñanza sobre el campo del sexto mandamiento que, en su conjunto, era considerado como grave «ex toto genere suo». Esta exasperación ha contribuido a causar un extremismo laxista e indiferentista en nuestros días. Es urgente que la teología moral se aclare en estos puntos».

Mons. J. de Jesús Pimiento Rodríguez, arzobispo de Manizales (Colombia), 94: «Para conseguir la renovación el Magisterio debe reafirmar la doctrina sobre la gravedad y realidad del pecado, sobre las normas para la auténtica formación de la conciencia...»; Card. L. López Trujillo, arzobispo de Medellín (Colombia), 216: «Debe desaparecer la idea de que los confines entre el pecado mortal y el venial pueden desaprecer objetivamente. Los criterios clásicos siguen siendo válidos, aunque necesitan ser profundizados. Hay que distinguir entre su carácter objetivo y la imputabilidad del pecado, que es un problema subjetivo».

69. Mons. M. L. Romero, obispo de Ciudad Guayana (Venezuela), 180.

70. Mons. M. Hermaniuk, arzobispo metropolita de Winnipeg de los Ucranianos, 86, 87.

71. Mons. L. Paskai, arzobispo c.i.s. di Kalocsa (Hungría), 130; Mons. S. Stefano Karlich, relator del Grupo B de lengua hispano-portuguesa, 208: Existe cierta ambigüedad sobre el concepto de pecado venial y mortal. Es deseable que, en la presentación de la doctrina, se utilicen categorías bíblicas más que filosóficas». 
del pecado y que los teólogos clarifiquen su sentido exacto con un lenguaje propio de nuestra cultura» ${ }^{72}$.

Igualmente descubren los Padres sinodales, tanto en los ministros como en los fieles, la ambigüedad de la noción del pecado venial y mortal ${ }^{73}$, debida a la falta de la claridad necesaria para distinguir los pecados graves en casos concretos (individuales) ${ }^{74}$, por lo que desean que el Sínodo «defina más claramente los criterios morales, es decir, las obras que llevan a la muerte y los caminos que conducen a la conversión» ${ }^{75}$, que «clarifique la distinción entre el pecado mortal y el venial, especialmente la idea de la opción fundamental, la eventualidad de una distinción ternaria (pecado mortal, grave y venial) y los medios pastorales para explicar dichas nociones») ${ }^{76}$.

Todas estas preocupaciones merecieron ser recogidas por el cardenal Martini en su relación del 30 de septiembre de 1983 y considerarlas como uno de «los objetivos principales» que debería conseguir el Sínodo ${ }^{77}$.

\section{La misma forma de celebración del sacramento}

Ya de entrada me atrevería a decir que se percibe una cierta admiración y como sorpresa cuando han oído hablar en el aula de la celebración del sacramento de la reconciliación. «El cardenal Martini, en su magnífica exposición

72. Mons. F. M. Costa, arzobispo de Huambo (Angola), 144; Mons. G. Singha, obispo de Owando (Congo), 147; Mons. B. Mve'Engone, obispo de Oyem (Gabón), 99.

Si olvidar la necesidad de traducir las categorías bíblicas a un lenguaje inteligible para el hombre de hoy. Card. G. Danneels, arzobispo de Mechelen-Brussel (Bélgica), 152-153: «Es imprescindible re-descubrir las raíces antropológicas seculares del sacramento de la reconciliación... El hombre moderno conoce un itinerario «penitencial» profano y dispone de todo un vocabulario. El estudio comparado de las analogías del vocabulario existentes entre el vocabulario cristiano y su equivalente secularizado, contribuirá a conocer mejor la especificidad del aquél... Nuestros contemporáneos encuentran dificultades en la comprensión del vocabulario bíblico y cristiano relativo a la redención. Los términos médicos, por el contrario, le son familiares. Por eso hemos de hacer fuerza apoyándonos sobre el aspecto de curación, psicológica y somática, presente en el sacramento de la reconciliación como en los demás sacramentos».

73. Mons. S. Stefano Karlich, relator del Grupo B. de lengua hispano-portuguesa, 208; Mons. Ph. Fanoco Kossi, obispo de Atakpamé (Togo), 162.

74. Mons. J. Wanke, administrador apostólico de Eerfurt-Meiningen, Berlín, 89; Mons. L. Averkamp, 209: «La Iglesia debe clarificar los principios fundamentales relativos a la moral sexual, con un justo equilibrio, libre de un falso rigorismo como también de un permisivismo libertino»; Card. G. Danneels, 205: «...el pecado sexual, que ha sido considerado excesivamente en otros tiempos, hoy parece no ser valorado...».

75. Mons. A. Tatianma Sanon, obispo de Bobo-Doulasso (Alto Volta), 164.

76. Card. G. Danneels, 204; Mons. R. Ridal, arzobispo de Cebú (Filipinas), 91: «El pecado: grave, moral, serio, que conduce a la muerte; venial, con énfasis en la intención y en las circunstancias, en contraposición a ese juzgar un acto partiendo de sus resultados y de sus consecuencias»».

77. Card. C. M. Martini, 64-5. 
del tema de este Sínodo, ha usado frecuentemente la palabra 'celebración'. Me pregunto: ¿Esta palabra, tan rica de significado litúrgico, es aplicada ex novo a este sacramento o existía ya desde su institución y en su evolución histórica como sacramento de la reconciliación?».

«Si decimos que ya pre-existía, ciertamente no ha sido ella la que ha caracterizado, con su rico significado litúrgico, la forma usada hasta ahora, del sacramento de la reconciliación. Tanto sacerdotes como fieles no hemos sentido, hasta hoy, las fuerzas de celebración alguna, digna de este nombre, con relación a este sacramento. Precisamente por ello este sacramento se ha convertido en una cosa tan poco atrayente».

«Por eso mismo nosotros, Padres de este Sínodo, debemos pararnos en este momento providencial para dedicar todas nuestras fuerzas, especialmente en las discusiones en grupo, a bosquejar una celebración litúrgica digna del nombre de este sacramento ${ }^{78}$.

Cuando se refieren al pasado, más que de «celebración» hablan de «un formalismo que empobrece la forma penitencial individual privada» ${ }^{79}$, de una administración «superficial» del sacramento, sobre todo cuando se trataba de niños ${ }^{80}$, de una administración «mecánica y rutinaria» del mismo ${ }^{81}$.

\section{CONCEPCIÓN DEL SACRAMENTO DE LA RECONCILIACIÓN}

\section{Don de Dios}

La reflexión sobre este sacramento podría seguir dos caminos: 1) estudiar comparativamente los esfuerzos de reconciliación humana y la realidad sacramental, tratando, en una segunda fase de articular ambas realidades o 2) dar la primacía al estudio de las riquezas que el sacramento encierra en sí mismo. Parece más acertado seguir la segunda hipótesis porque de seguir la primera «se relativizaría el sacramento y se correría el riesgo de considerarlo como un medio, entre otros muchos, de reconciliación y como un gesto de Dios como sobreañadido a los esfuerzos humanos para sacramentalizarlos y darles plenitud». ${ }^{82}$. Y no es así porque la «Iglesia como sacramento, y también el mismo sacramento, une en un todo lo humano y lo divino, lo social y lo espiri-

78. Mons. L. Kanene Obiefuna, obispo de Awka (Nigeria), 106-7.

79. Mons. S. Stefano, relator del Grupo B de lengua hispano-portuguesä, 208.

80. Mons. S. E. Carter, arzobispo de Kingston (Jamaica), 67.

81. Mons. J. Babatunde Adelakun, obispo de Oyo (Nigeria), 83; Mons. A. B. Vaughan, obispo auxiliar de New York, 712.

82. Mons. R. Coffy, arzobispo de Albi (Francia), 114.

83. Mons. W. Napier, obispo de Kokstad (Sudáfrica), 122. 
tual...» ${ }^{83}$, pero es el «misterio de Cristo el que se constituye en garantía de autenticidad y de eficacia de la misión reconciliadora de la Iglesia. No son nuestras fuerzas las que nos purifican y nos conducen al camino recto, sino el Espíritu de Dios. Si los hombres se sienten cada día más unidos y reconciliados, no se debe únicamente a que se conocen mejor y han superado sus diferencias, sino a Dios que, en Cristo, les ha concedido la gracia de ser más hermanos».

Si la reconciliación es presentada como un simple tentativo de poner de acuerdo a las partes en conflicto para alcanzar una discreta convivencia pacífica, entonces el anuncio profético de la Iglesia queda reducido a una oferta más de salvación, entre tantas que ofrecen las ideologías y la evangelización será sometida a no pocos prejuicios sociales y políticos».

«La misión reconciliadora de la Iglesia gozará de credibilidad ante el hombre de hoy si testimonia y celebra la unión entre el misterio sacramental y la liberación radical del hombre en el misterio de Cristo» ${ }^{84}$.

Sin olvidar, pues, el compromiso y el esfuerzo humanos, ha de quedar claro que la iniciativa de nuestra reconciliación la ha tomado el Padre; que la reconciliación es, ante todo, obra divina y que es necesario considerarla en relación con las tres Personas de la Santísima Trinidad ${ }^{85}$; que «la paternidad divina es la raíz última de nuestra reconciliación» ${ }^{86}$; que «el origen de la reconciliación está en el amor del Padre, que, por su gratuita iniciativa, ha establecido un plan en cuyo centro está el misterio pascual de Cristo. El Padre quiere reconciliarnos consigo en Cristo y así amar en nosotros aquello que ama en el Hijo Unigénito. El Hijo es el que lleva a plenitud el plan del Padre. Hemos de salvar este mundo, falto de fraternidad, con la verdad de la paternidad del Padre y de la fraternidad de Cristo en el cual somos de verdad hijos de Dios y hermanos entre nosotros» ${ }^{87}$.

"Quiero hablar de la paternidad divina como raíz última de nuestra reconciliación. Nuestros contemporáneos, especialmente los jóvenes y los pobres, son particularmente sensibles a esta experiencia de la paternidad de Dios. Es necesario, por tanto, hablar a los hombres de nuestro tiempo, oprimidos por la soledad y la tristeza, de un Dios «Padre lleno de misericordia y de toda consolación». En esta perspectiva el pecado es el alejarse del Padre, el rechazo de su amor y de su amistad y la conversión sería el retorno a la casa paterna, el recuperar la amistad y la alegría del encuentro. Ésta ha sido la su-

84. Mons. C. Amigo Vallejo, arzobispo de Sevilla, 92.

85. Mons. E. E. Karlich, arzobispo auxiliar de Paraná (Argentina), 124.

86. Card. El Pironio, 142.

87. Mons. E. E. Karlich, 124. 
blime pedagogía de Cristo, que nos ha revelado al Padre y se ha constituido en la única vía por la que nosotros podamos llegar al Padre».

«Tres observaciones prácticas se deducen de esta experiencia de la Paternidad divina: la alegría de la reconciliación, la fraternidad universal y la necesidad de una buena formación de los confesores para que sean «sacramento del Padre». Así daríamos respuesta a la insistente petición del hombre de hoy, sobre todo de los jóvenes y de los pobres: «Muéstranos al Padre y esto nos basta» (Gv. 14,8) ${ }^{88}$. Y es que el hombre de hoy necesita que se le explique «con un lenguaje claro, que Dios no es el adversario del hombre, ni le humilla ni empobrece cuando le ofrece su perdón, sino todo lo contrario» ${ }^{89}$.

\section{Dimensión cristológica del sacramento}

«El ministerio de la Iglesia al servicio de la reconciliación es de naturaleza religiosa y se fundamenta en la acción redentora de Cristo, que invita a la conversión y nos comunica la vida nueva en el amor» ${ }^{90}$.

«En el sacramento Cristo es el agente principal. El actúa con su fuerza, penetra y cambia los actos del penitente para conseguir el perdón y la reconciliación con Dios y con la Iglesia. Cristo, con su fuerza divina, penetra cuanto realiza el penitente. El sacramento es sacramento de Cristo y a través del sacramento actúa Cristo. Él, con un gesto infaliblemente omnipotente, renueva y cambia al pecador en penitente. Él puede transformarlo en un auténtico colaborador de la reconciliación, $y$, no raras veces, en holocausto expiatorio. Tal es la propiedad peculiar de este sacramento» ${ }^{91}$.

«La estructura trinitaria determinante de la fe cristiàna (in Spiritu cum Christo et ad Patrem) no impide acentuar el carácter eminentemente cristológico del proceso de la reconciliación y de la penitencia. Dentro de la multiplicidad de formas de interpretación de la cristología a lo largo de los siglos, hoy se orienta hacia una presentación de Cristo como «existente per» (proexistent, H. Shürmann). A través de los siglos nos hemos encontrado con el Cristo Maestro y Pantocrator de la antigüedad, con el hombre de dolores de las cruzadas y de los tiempos de epidemias del medioevo, con la imagen del Sagrado Corazón y la de Cristo Rey y finalmente con el Cristo cósmico de Theilard de Chardin. Hoy es particularmente útil la descripción de la fórmula «Jesucristo, paz y reconciliación». El principio «per» es una categoría eminentemente cristiana y alcanza su punto culminante en el «pro nobis» (por nosotros) del mis-

88. Mons. E. Pironio, 142.

89. Mons. J. Alves, obispo de Coimbra, 157.

90. Mons. G. Díaz Merchán, arzobispo de Oviedo, 110.

91. Card. F. Tomásek, arzobispo de Praga, 166. 
terio de Cristo. El misterio, aquí presentado, de la radicalización y de la universalidad de la «existencia per», también expresada en la extensión de Cristo en su dimensión vertical y horizontal de la Cruz, se basa en su intrínseca existencia teológica. Efectivamente, sin ella Cristo, desde el punto de vista puramente antropológico, jamás podría ser tan radicalmente «existente per» (proexistent). La fundamental radicalidad y universalidad de esta «existencia per» (proexistent) de Cristo solamente puede alcanzarse hoy a través del camino de la penitencia y así puede dar a la humanidad la conciencia de ser la 'gran familia' de Cristo» ${ }^{92}$.

«Corresponde a la Iglesia la misión de ofrecer y presentar al mundo el Cristo que tiene una palabra, un mensaje de perenne validez para todas las situaciones de la vida humana. A quienes se encuentran en la situación de pecado la Iglesia ofrece el Cristo que perdona; a los que sufren persecución, pobreza y hambre etc. les ofrece el Cristo de las Bienaventuranzas; a los que se entregan a la violencia, a los opresores, a los explotadores de los demás, a los detentadores del poder, les ofrece y presenta el Cristo del mandamiento nuevo que debería regular las relaciones humanas con el amor-caridad que reconcilia al hombre con el hombre, a los grupos sociales entre sí, y a las naciones entre ellas. Ayudará al hombre, que a causa del pecado ha perdido el sentido de Cristo, a re-encontrarlo y a abrirle su corazón para un encuentro personal en el que pueda obtener el perdón y la reconciliación con Dios, consigo mismo y con sus semejantes mediante el sacramento de la penitencia, que sella de manera visible este perdón y esta reconciliación» ${ }^{93}$.

\section{Acción del Espíritu Santo}

«Este Sínodo se ha prefijado la meta, entre otras, de encontrar los medios apropiados y adecuados para llevar a los hombres de hoy a una conversión y reconciliación total y genuina entre los individuos, las familias y la sociedad. No podrá encontrar tales medios sino en Cristo, su Redentor, en su Evangelio y en la potencia del Espíritu Santo.

«El Espíritu Santo renueva continuamente a la Iglesia mediante muchas personas y movimientos, y los obispos deben discernir diligentemente, en el interior de la propia Iglesia, la iniciativa del Espíritu Santo en los variados movimientos de renovación y reconocerlos y sostenerlos» ${ }^{94}$.

92. Mons. A. Nossol, obispo de Opole (Polonia, 178-179.

93. Mons. P. Tzadua, arzobispo de Metropolita de Addis Abeba, 70.

94. Mons. P. Chung Hoang Ting, arzobispo de Kuching (Malasia), 163. 


\section{Escuela de conversión}

El sacramento de la reconciliación es presentado insistentemente en relación con la conversión. Debe ser considerado «como una verdadera escuela de conversión» que aleja del pecado y abre a la vida de fe, esperanza y caridad siempre creciente ${ }^{95}$; como invitación animadora a emprender el nuevo camino de «convertirse y creer en el Evangelio» ${ }^{96}$, que es la forma más radical de penitencia y cuya observancia comporta un compromiso constante por comprender y vivir las exigencias del Evangelio a la luz de las situaciones de nuestra vida ${ }^{97}$.

En la celebración de este sacramento se concederá una importancia real, primaria y fundamental, «a la contrición o verdadera conversión» ${ }^{98}$, puesto que la verdadera conversión interior es de una necesidad absoluta para llegar a una auténtica reconciliación ${ }^{99}$. Ha de quedar claro que «la confesión no sustituye a la conversión. La exigencia fundamental de Cristo es la conversión del corazón y de la vida. Existe el peligro de que la confesión sea considerada como una sustitución de la conversión y de que la decisión de comenzar una nueva vida no sea tomada suficientemente en serio. Por tanto se debe subrayar más la importancia de la decisión personal radical hacia un futuro nuevo y la necesidad de dar pruebas concretas de tal decisión. La actuación de la confesión a servicio de la conversión tiene también un significado antropológico y ecuménico. Tres sugerencias prácticas:

1. Toda la vida de los cristianos y de la Iglesia debe ser un constante camino de conversión, que no termina nunca y que no puede ser absolutamente sustituido.

2. En la catequesis del sacramento de la reconciliación hay que explicitar mejor la dimensión de futuro. El sacramento tiene siempre dos dimensiones: el pasado y el futuro.

3. En la acción pastoral no se debe insistir solamente sobre la frecuencia de la confesión, sino también sobre el compromiso de conversión ${ }^{100}$.

95. P. J. Pfab, Superior General de los Redentoristas, 87; Mons. S. E. Carter, arzobispo de Kingston (Jamaica), 168: «La relación introductiva presenta una laguna: Trata de la reconciliación y de la penitencia casi exclusivamente como penitencia por el pecado grave, principalmente por el pecado grave. En cambio el Vaticano II, en el cap. V de la Constitución sobre la Iglesia, enseña no solamente que todos hemos sido llamados a evitar los pecados graves, sino también que todos hemos sido llamados «a la caridad por la que amamos a Dios y al prójimo por amor a Dios».

96. Card. C. M. Martini, 191.

97. P. J. Vaugh, Ministro General de los Hermanos Menores, 186.

98. Mons. D. Castrillón Hoyos, relator del Grupo A de lengua española, 198.

99. Card. C. M. Martini, 64.

100. Mons. A. Sustar, arzobispo de Lubiana (Jugoslavia), 115; Mons. Austin B. Vaughan, 
La celebración del sacramento debe significar «un paso decisivo hacia la conversión ${ }^{101}$, hacia una total y genuina conversión y reconciliación ${ }^{102}$. Se recuerda con cierta nostalgia, y hasta se quisiera revivir el carácter de camino de conversión que este sacramento tenía en la antigüedad. Era «un camino que comprometía por un largo período de tiempo. Se consideraba que una conversión profunda, que abarcara a todo el hombre, exigía una larga práctica. Por eso la Iglesia estableció períodos de penitencia, sobre todo en cuaresma ${ }^{103}$.

«El fundamental y primer significado de la penitencia cristiana es el expresado en el bautismo: el bautismo comporta la confesión de la fe y el abandono de la injusticia de los hijos de Adán. Por tanto, el compromiso de buscar la nueva justicia, proclamada por Jesucristo en el sermón del monte. La justicia de los hombres lo más que lográ es contener los conflictos; la nueva justicia consiste en reconocer al otro como hermano. La comunión fraterna y la eucaristía constituyen, pues, el objetivo al que mira la penitencia cristiana, y es además, el punto de partida de la misión de la Iglesia de cara a todo el género humano» ${ }^{104}$.

En el sacramento «la realidad primaria es nuestra llamada a la santidad, que establece una íntima relación con Dios, que es dañada por el pecado» ${ }^{105}$.

arzobispo auxiliar de New York, 106: «Las confesiones han descendido a causa de una disminución del sentido de la necesidad de redención. Parece como que la salvación estuviera asegurada para todos y ninguno tuviera miedo de condenarse...»; Mons. H. J. Spital, obispo de Trier (Rep. Fed. de Alemania), 177: «El documento final de la Comisión Teológica Internacional de 1982 afirma que «la penitencia, tal como se practica en los últimos tiempos en la Iglesia, la experimentan los cristianos como vacía e ineficaz». Por ello me paro sobre el problema del formalismo».

«Si un cristiano se preocupa más de la acusación completa que de arrepentirse, está privilegiando al aspecto jurídico».

«Si alguno se limita solamente a buscar fórmulas en las listas de pecados» más que a reflexionar sinceramente sobre su comportamiento pecaminoso, cae en un ritualismo equivocado».

«Éstas, y otras actitudes similares equivocadas, producen una fractura entre la vida y la práctica del sacramento, que ha sido, y quizás siga siendo, el peligro más grave contra una verdadera práctica viva del sacramento de la reconciliación».

101. Mons. J. de Jesús Pimiento Rodríguez, arzobispo de Manizales (Colombia), 94.

102. Mons. P. Chung Hoang Ting, arzobispo de Kunching (Malasia), 163; Mons. J. Delicado Baeza, arzobispo de Valladolid, 134: «Proclamar el Reino de Dios y llamar a la conversión: Cristianismo popular y cristianismo de pequeños grupos (ambas cosas porque es necesario un encuentro personal con Dios en los pequeños grupos, en un contexto socio-cultural preciso). Anunciar con audacia profética, con todos los medios posibles, la Buena Nueva en su aspecto escatológico de la vida eterna y en su capacidad de fermento de promoción humana integral».

103. Rev. G. Holzherr, abad de María Heinsiedeln (Suiza), 123; «...la experiencia de los grandes santuarios marianos «nos enseña que el sacramento de la penitencia en su forma de confesión individual constituye el punto culminante de camino penitencial...», dice el Card. F. Macharski, arzobispo de Kraków (Polonia), 75; Card. G. B. Hume, arzobispo de Westminster (Inglaterra y Gales), 152: «La fe se requiere durante toda la vida y el estado de conversión debe ser permanente. Somos o debemos ser una Iglesia del arrepentimiento y de la fe»; y el Card. G. Danneels, 152-3 habla del «itinerario penitencial del hombre moderno».

104. Card. C. M. Martini, 191.

105. Mons. P. G. Cullinane, relator del Grupo A de lengua inglesa, 195. 
Una conversión que ha de ser progresiva, puesto que «toda la economía sacramental se armoniza y finaliza hacia el hacer experiencia y vida» el misterio de la reconciliación, que parte del pecado del hombre purificado y redimido pero avanza hacia la total transfiguración del hombre «en nueva criatura según Dios», donde la plenitud de la caridad y el misterio de la comunión trinitaria convierten al hombre verdaderamente en hijo de Dios y su historia en universal fraternidad en Cristo» ${ }^{106}$.

Por ello la Iglesia no debe pararse excesivamente sobre el pecado, como si fuera una realidad merecedora de ser tomada en cuenta por sí misma. Debe tratar de explicar su realidad, pero sencillamente como un momento necesario de un PROCESO en el cual el pecador se va liberando progresivamente del pecado mediante la conversión. Quien está inmerso en el pecado o en situaciones de pecado se va haciendo ciego en relación a su estado. A quienes sufren esta situación la Iglesia debe proclamarles la fidelidad y amor de Dios, la victoria sobre el pecado obtenida por Cristo, el acceso ilimitado que ahora pueden tener a la gracia recreante de Dios y una opción distinta de la del pecado y de la iniquidad, porque todo esto ha sido hecho posible por el Espíritu de Cristo» ${ }^{107}$.

\section{Conversión celebrada festivamente}

El sacramento debe gozar de una presentación positiva, festiva, repiten muchas intervenciones, tanto en el plano sustancial o de contenido como a nivel formal o manera de celebrarlo.

Es imprescindible que la catequesis libere a este sacramento de todos

106. Card. A. A. Ballestrero, arzobispo de Turín (Italia), 152; Mons. C. Morelos y Flores, obispo de Butuan (Filipinas), 111-112.

107. Card. J. L. Bernardin, arzobispo de Chicago, 171; Mons. M. Maître, obispo de Bambari, (República Centroafricana), 188: «El remedio acertado a la pérdida del sentido del pecado y a la disminución de la frecuencia del sacramento de la reconciliación pueden ofrecerlo las bellas celebraciones comunitarias con absolución colectiva». La lectura de la palabra de Dios, la homilía, el examen de conciencia, y a veces la confesión de algunas culpas devolverán el sentido de la culpa personal y de la misericordia divina juntamente con auténtico deseo de conversión.

«Los fieles, así preparados, descubrirán después la necesidad de un encuentro personal con el sacerdote, que se desarrollará con una actitud distinta de aquella que acompañaba a las confesiones en serie, con ocasión de las grandes solemnidades...».

Nos encontramos con el problema de las situaciones matrimoniales irregulares. No hay solución inmediata posible. Toca a personas conscientes de su pecado, que sufren, que desearían salir de tal estado...».

«Los pastores deberían tener la posibilidad de discernir qué personas tienen un verdadero deseo de conversión y no verse obligados a privarles de la misericordia del Señor, que ha venido no para los sanos sino para los enfermos». 
aquellos elementos que le han convertido en un sacramento sombrío, poco atraeyente ${ }^{108}$.

El sacramento de la reconciliación debe convertirse en la «proclamación decidida y valiente de la Buena Nueva de la reconciliación», de manera que la comunidad creyente «entre en el movimiento universal de reconciliación, favorecida por el espíritu de acogida y de ayuda recíprocas... aunque sin olvidar de luchar contra los obstáculos que se oponen a la reconciliación...» ${ }^{109}$. Es necesario presentarlo como llamada «a un amor universal, a la justicia, a la misericordia y al perdón y es necesario impulsar a las personas al compromiso de conocerse recíprocamente y a crear confianza en ellas» ${ }^{110}$. Debe presentarse como un «apoyo de la responsabilidad del hombre que solamente, reconociendo su dignidad y libertad, es capaz de conversión y reconciliación» ${ }^{111}$; ayudarle a que experimente el sacramento, al igual que a la Iglesia, «como un lugar y espacio espiritual histórico en el que el hombre pueda experimentar los sentimientos de 'hijo pródigo' ante la misericordia de Dios Padre...» ${ }^{112}$; como un

108. Mons. T. F. Litle, arzobispo de Melbourne (Australia), 104: «Las palabras de la encíclica Dives in misericordia: «el objeto de misericordia no se siente humillado, sino re-creado» expresan una verdad que el Sínodo debe exponer claramente. Quienes no han llegado al conocimiento de tal verdad evangélica, están inclinados a ver el sacramento de la reconciliación como un deber pesado. Quienes la han experimentado en su vida, valoran el sacramento»; Mons. N. Kokora Tekry, obispo de Gagnoa (Costa de Marfil), 117: «Los ritos actuales de la celebración del sacramento de la penitencia le han convertido en un sacramento que recibimos para evitar el infierno. Ante esta actitud de temor servil, es urgente promover una catequesis que subraye, ante todo, el amor misericordioso de Dios, las riquezas reales del don de su perdón y el significado de fiesta comunitaria de la reconciliación en Cristo. He aquí por qué esperamos unas formas de celebración de la reconciliación, más concretas y apropiadas, que le conviertan en una fiesta de toda la comunidad».

109. Mons. A. Perraudin, arzobispo de Kagbayi (Rwanda), 68; Mons. D. Worlock, arzobispo de Liverpool, 68-69: «La Iglesia debe condividir los sufrimientos humanos y trabajar por encontrar una solución a los conflictos y por la reconciliación de los pueblos. De esta manera los pueblos van acercándose unos a otros y reconocen que la reconciliación viene sólo de Dios.

«La lucha común por la justicia social permite a los cristianos descubrir sus vínculos de unidad y su necesidad de reconciliación.

«La búsqueda de la justicia social y de la paz lleva a desear la reconciliación con Dios y prepara el camino hacia el sacramento... Según la mentalidad del hombre de hoy el camino hacia Dios pasa a través del corazón humano con sus complejos, deseos, temores, alegrías y sufrimientos. Considero que éste sea el mejor camino para lograr que el hombre moderno comprenda su necesidad de reconciliación con Dios a través del sacramento de la «confesión».

Mons. F. Favreu, obispo de Nanterre (Francia), 180: «El sacramento de la reconciliación es una buena nueva decisiva. Nos dice que el amor de Dios es más fuerte que el pecado; que nada se ha perdido definitivamente; que la historia no es una fatalidad; que el hombre puede responder nuevamente a su vocación de hijo de Dios»; Mons. M. Hermaniuk, arzobispo metropolita de Winnipeg de los Ucranianos, 87.

110. Mons. S. F. Hamao, obispo de Yôhohama (Japón), 66.

111. Card. A. López Trujillo, arzobispo de Medellín (Colombia), 82.

112. Card. J. C. Aramburu, arzobispo de Buenos Aires, 79. 
lugar en el que el hombre «reconquista su paz interior y exterior ${ }^{113}$, es decir, «con Dios, consigo mismo y con el prójimo» ${ }^{114}$; como «un lugar privilegiado» de la verdadera libertad, aquella que no consiste en atribuirse el derecho de determinar apriorísticamente los valores y normas, de establecer lo que es bueno o malo, sino aquella que, liberando al hombre de las ilusiones de una falsa autonomía, le muestra la posibilidad de recuperar su verdadero estado de hijo de Dios...» ${ }^{115}$. También será lugar privilegiado de la verdadera libertad porque «los signos de los tiempos evidencian un declinar del ejercicio de la responsabilidad individual. El hombre cada vez se muestra más pasivo. Su vida es gobernada, hasta en los más pequeños detalles, por la administración civil. El hombre es manipulado por la presión de los grupos sociales que obedecen a normas y exigencias propias sin pararse a considerar el bien común» ${ }^{116}$.

Lo veremos como un sacramento que proyecta toda su capacidad creadora en el sentido de hacer a los hombres «más expedito el camino hacia la santidad» y de conseguir que «asuman las responsabilidades personales que contribuyen a la paz y a la justicia» ${ }^{117}$.

Hemos de vivir y ayudar a los hombres a vivir este sacramento como una «confesión de alabanza» ${ }^{118}$, porque celebramos la reconciliación «no tanto movidos por el temor a perder el paraíso, cuanto, sobre todo, por el deseo de ser reintegrados en el amor de Dios y del prójimo» ${ }^{119}$. "La reconciliación, para ser creíble por los hombres, debe ser presentada como una teología de la vida feliz. La felicidad es un fenómeno humano querido por el mismo Creador» y esto en unos momentos en los que «los hombres buscan razones para vivir y

113. Card. A. López Trujillo, 82.

114. Mons. M. Hermaniuk, arzobispo metropolita de Winnipeg de los Ucranianos, 86.

115. Card. C. M. Martini, 65.

116. Mons. D. J. Ryan, obispo de Dublín, 91; Mons. J. Mercieca, arzobispo de Malta, 134135: «La reconciliación, que es la conversión del hombre a Dios, pide también la reconciliación con el prójimo, con el hombre; exige nuestro sincero compromiso de ayudar a los demás en la construcción de una sociedad más humana, sin descuidar la denuncia, aunque con espíritu de caridad, de las injusticias sociales.

«La reconciliación con Dios nos pide un sentido vivo y activo de nuestra responsabilidad para con los demás contemplados en las diversas circunstancias de su vida. El sentido de responsabilidad nos impide permanecer pasivos ante los injustos sufrimientos de los demás. Nos impulsa a hablar en su lugar siempre que ellos se vean imposibilitados para hacerlo: Éstos son los verdaderos pobres porque necesitan de nuestra voz para hacerlo.

«Si el sacramento es presentado bajo estos dos aspectos, se les anima a acercarse a él, porque, reconciliando al hombre con Dios y con sus congéneres, echa el fundamento esencial para la reconciliación de los hombres entre sí».

117. Mons. P. G. Gullinane, relator del Grupo A de lengua inglesa, 195; Card. B. Gantin, 74.

118. Card. M. Cê, patriarca de Venecia, 130.

119. Mons. S. Kocisko, arzobispo metropolita de Pittsburgh de rito bizantino, 144. 
esperar»y en los que «muchos jóvenes no creen más en la felicidad» ${ }^{120}$. Lo presentaremos como «un mensaje de esperanza, dirigido a los hombres de buena voluntad, tratando de hacerles comprender que, con la ayuda de Dios, el hombre puede vencer sus debilidades y reconciliarse con Dios, consigo mismo y con los demás» ${ }^{121}$; como un sacramento en relación estrecha con «las perspectivas de esperanza y con las señales de reconciliación ya existentes», como «colaboración con los programas, ya existentes, de reconciliación mundial», como «estímulo para las legislaciones que promueven la unidad», dando prioridad a la formación de la conciencia y desarrollando una catequesis sobre la reconciliación y la penitencia ${ }^{122}$... Nosotros mismos, en cuanto confesores, lo viviremos como un «oficio de caridad»" ${ }^{123}$.

La catequesis se centrará en los objetivos de la reconciliación que el cardenal Paulo Evaristo Arns, arzobispo de São Paulo (Brasil) resume como sigue:

1. El don del Amor: El testimoniar el don del amor en un momento determinado y dividido por un espíritu de muerte constituye un desafío para la evangelización y la reconciliación.

2. El don escatológico: Occidente está sufriendo la tentación de confundir el Reino de Dios con la sociedad y sus sistemas sociales. Oriente lo busca en la interioridad misma del hombre. El don trascendente y al mismo tiempo la comunicación de la vida del Padre y del Hijo constituyen nuestras metas.

3. El don pascual de la victoria: El mundo aparece como hostil y dominado por los ídolos del tener, del poder y del placer. A través de la victoria de Cristo en la Cruz el Espíritu viene al mundo como promesa de plenitud de vida. Él es la Buena Nueva para los pobres, perseguidos, marginados, grupos y clases humillados. A sus discípulos los conduce por el camino de la pobreza y de la conversión.

4. El don mesiánico: La reconciliación es el testimonio del Espíritu mesiánico de Jesús. Comporta el juicio del mundo sobre el pecado y la justicia. La acción de la reconciliación, cuando se trata de conflictos, dominio de un sexo sobre otro o sobre las razas, clases etc. o de una nación sobre otra, consiste en la búsqueda común de nuevas alternativas. El don mesiánico por excelencia es la formación del Pueblo que vive en comunión, es la realización de lo social según la originalidad propia del Evangelio, es la vida del Pueblo según el mandamiento nuevo.

120. Card. A. P. Khoraiche, patriarca de Antioquía de los Maronitas, 173-174.

121. Mons. M. Hermaniuck, arzobispo metropolita de Winnipeg de los Ucranianos, 87.

122. Mons. A. Mabutas y Llorén, arzobispo de Davao (Filipinas), 133.

123. P. J. Pfab, Superior General de los Redentoristas, 87 . 
5. El don de la libertad: El Espíritu asegura los procesos de liberación de la historia... la reconciliación tiende hacia la revelación y defensa de la dignidad del sujeto humano como a su propio objetivo. En los conflictos suscita la palabra de verdad y de discernimiento. Asegura la libertad y la comunión del Pueblo. La reconciliación es la comunicación de la plenitud de vida de Cristo, unido al Padre. «Estas son las categorías del Espíritu para juzgar y transformar la sociedad» ${ }^{124}$.

Y todo este contenido festivo, de liberación humana, requiere una forma de celebrarlo, una «representación más comprensible, también desde el punto de vista lingüístico y celebrativo, del acontecimiento «reconciliación y penitencia» ${ }^{125}$, de tal forma que es «necesaria una investigación creativa que encuentre expresiones adecuadas de reconciliación», porque «muchos católicos no consiguen comprender el mensaje de la reconciliación como una «buena nueva», mucho menos si tal mensaje deben captarlo a través de la actual forma individual de reconciliación» ${ }^{126}$. Tan estrechamente se relacionan la misión de la Iglesia con la forma de celebrar este sacramento que aseguran que la Iglesia llevará a cabo su misión de Iglesia reconciliada y reconciliadora «mediante una práctica renovada de la penitencia y de la reconciliación» ${ }^{127}$.

Todo esto lo comprenderá solamente quien haya experimentado en su vida que aquél sobre quien recae la misericordia divina no es humillado, sino más bien recreado ${ }^{128}$, que Dios «no es adversario del hombre, ni le humilla y empobrece cuando le ofrece el perdón, sino todo lo contrario» ${ }^{129}$.

\section{Medicina para la fragilidad humana}

«El mundo está enfermo y busca una medicina» ${ }^{130}$ y el sacramento de la reconciliación es una medicina eficaz que no solamente perdona los pecados, sino que ofrece también una gracia potente para curar las heridas dejadas por el pecado y sus consecuencias... El Redentor da respuesta, divinamente eficaz, a toda la problemática de la lucha espiritual del penitente» ${ }^{131}$.

Pudiéramos pensar en un puro automatismo o como en una acción mági-

124. Card. P. E. Arns, arzobispo de S. Pablo (Brasil), 186-187.

125. P.E.Viganó, Rector Mayor de la Sociedad Salesiana, 78.

126. Mons. J. B. Möller, obispo de Groningen (Holanda), 111.

127. Card. C. M. Martini, 219.

128. Mons. F. Little, arzobispo de Melbourne (Australia), 104.

129. Mons. J. Alves, obispo de Coimbra, 157.

130. Card. F. Tomásek, arzobispo de Praga, 79-80.

131. Card. O. Rossi, 140. 
ca. Pero no es así, porque el sacramento sólo lo experimenta como medicina, fuerza y energía quien lo celebra con una participación personal y consciente ${ }^{132}$, en cuyo caso el sacramento compromete a una lucha abierta contra su propio egoísmo, que es el pecado, tanto en sus manifestaciones personales como en las sociales. La recta concepción del sacramento de la reconciliación, al igual que la concepción acertada de la Iglesia, no soporta que el sacramento sea reducido al ámbito de lo puramente espiritual ni tampoco que se le interprete con categorías puramente socio-políticas. El sacramento de la reconciliación, al igual que la Iglesia como sacramento, estructura armónicamente entre sí lo humano y lo divino, de manera que el esfuerzo por crear la reconciliación a nivel social pertenece al signo sacramental de la reconciliación con Dios ${ }^{133}$.

\section{Energía histórica capaz de poner los fundamentos a una concreta «cul- tura del amor» ${ }^{134}$}

«Reconciliación y penitencia como camino para la construcción de una cultura mundial del amor. La expresión «cultura del amor» la acuñó Pablo Vi y la ha desarrollado Juan Pablo II, en cuya encíclica Dives in misericordia obtiene la categoría de «Charta Magna».

«La estructura de esta cultura se apoya en una cuádruple escala de valores que son: el primado de la persona sobre el objeto, de la ética sobre la técnica, del 'ser más' sobre 'el tener más' y de la misericordia sobre la justicia. Exige simplemente un esfuerzo para dejar que la fuerza del amor domine en todos los campos de la vida personal y social. Grandes santos contemporáneos y hombres heróicos, como Maximilian Kolbe, Edith Stein, Alfred Delpe, Dietrich Bonhoeffer, el arzobispo Romero y otros numerosos grandes confesores son emblemáticos en este sentido. Como grandes cristianos han emprendido el camino hacia la única revolución posible para nosotros, derramando no la sangre de los demás sino la propia: la victoria del amor sobre el odio» ${ }^{135}$.

132. Card. O. Rossi, 140: «...los laicos sienten que su reconciliación con Dios es también experiencia de liberación humana. El sacramento de la reconciliación es una «medicina» para la fragilidad del hombre, si su celebración es vivida de manera personal...».

133. Mons. W. Napier, obispo de Kokstad (Sudáfrica), 122.

134. P. E. Viganó, Rector Mayor de la Sociedad Salesiana, 78.

135. Mons. A. Nossol, obispo de Opole (Polonia), 106. 


\section{COMPRENSIÓN DEL PECADO}

He aquí algunos trazos descriptivos del pecado, con los que los Padres esperan responder a las expectativas.

1. El pecado sólo es conocido, en su significado pleno, cuando es considerado a la luz de Dios

«Si la Iglesia desea realmente reconciliar al hombre con Dios, consigo mismo y con el prójimo, debe restablecer la verdadera noción del pecado...» ${ }^{136}$.

Las intervenciones sinodales orientan su reflexión hacia la concepción teológica del pecado, aunque sin olvidar sus relaciones con la concepción ética ${ }^{137}$. Mons. O. Rodríguez Madariaga nos recuerda que, para «descubrir el verdadero sentido del pecado, es necesaria toda una pedagogía del sentido sacramental y del sentido de Dios. Las actitudes fundamentales sobre las que se basa dicha pedagogía son: 1) la proximidad de Dios; 2) la acción constante del Espíritu Santo; 3) la fe renovada por la fuerza del Evangelio, como energía transformadora; 4) la aceptación positiva del mundo en que vivimos; 5) la presencia del misterio de iniquidad; 6) el reconocimiento de la reconciliación en Cristo, para siempre, a través de la comunidad; 7) la aceptación de la realidad que es que el cristiano consigue su finalidad sólo cuando vive a la luz de la Pascua de Cristo, nacido para la reconciliación y como ejemplo de reconciliación ${ }^{138}$.

«Del pecado no se puede hablar sino en relación con Dios. Pero esta relación pasa necesariamente a través de Cristo Jesús (Mt 1,21; Rom 5,1-11). Donde ha abundado el pecado ha sobreabundado la gracia (Rom 5,20). Por eso el Evangelio es de verdad la gran buena nueva para el pecador» ${ }^{139}$.

«La plena comprensión del pecado se tiene en el contexto de la historia de la salvación escatológica, concebida por el amor gratuito del Padre, realizada

136. Mons. M. Hermaniuk, arzobispo metropolita de Winnipeg de los Ucranianos, 86.

137. Card. C. M. Martini, 63; Mons. M. Lezardo Romero, obispo de Ciudad Guayana (Venezuela), 180: «Creo que no se reconoce debidamente la conexión profunda entre el pecado, entendido teológicamente, y sus consecuencias sociales. Por ello mientras crece, en la Iglesia el interés por el compromiso social, decrece el compromiso penitencial».

138. Mons. O., Rodríguez Madariaga, administrador apostólico de Santa Rosa de Copán (Honduras), 160-161; Mons. F. Mkhori, obispo de Chikwawa (Malawi), 140-141.

139. Mons. L. Monsengwo Parinya, relator del Grupo B de lengua francesa, 205. 
por el Hijo y actualizada permanentemente por Espíritu Santo, mediante la Iglesia...» ${ }^{140}$.

La paternidad de Dios es central en el Evangelio ${ }^{141}$, de manera que «no comprenderemos toda la gravedad del pecado mientras no hayamos entendido la profundidad del amor que Dios nos ha revelado en Jesucristo» ${ }^{142}$.

En este confrontar el pecado con el amor de Dios se encuentra «la verdadera noción del pecado», cuya esencia consiste en «rechazar el amor de Dios», en «la ruptura de la única relación de amor que puede conducirnos a una genuina relación con Dios y con los demás» ${ }^{143}$. En la perspectiva del «Padre de la misericordia y de toda consolación (II Cor 1,13 ) el pecado es «un alejamiento del Padre, un rechazo de su amor y amistad, al mismo tiempo que la conversión es «el retorno a la casa paterna, la recuperación de la amistad y de la alegría del encuentro» ${ }^{144}$. Siempre, desde la óptica de la paternidad divina y de nuestra filiación, el pecado es «la alienación de Dios y de nosotros mismos», en cuanto que nos oponemos a la transcendencia de Dios y a la justa comprensión de la dignidad del hombre ${ }^{145}$. «El pecado es personal pero abarca también las más amplias relaciones con los demás» ${ }^{146}$. «Es rebelión y división interior de la persona y como tal origen de todas las tensiones y divisiones de la humanidad» ${ }^{147}$. En definitiva el pecado es la negación de la fe en el amor misericordioso de Dios ${ }^{148}$; es el antisacramento del amor misericordioso de Dios ${ }^{149}$; es la negación de la transcendencia y del plan divino, plan de Dios que destina al hombre a entrar en comunión de vida y amor con Dios, mediante una vida de fraternidad con el prójimo y usando del mundo como medio que le ayude a conseguir su último fin ${ }^{150}$, que es «la reconciliación como iniciativa divina y don de Dios a fin de que los hombres participen en su amor en la plena comunión con Dios y entre sí» ${ }^{151}$.

140. Card. A. Sabattani, relator del Grupo de lengua latina, 201; Mons. F. Sebastián Aguilar, obispo de León, (España) 121.

141. Card. G. B. Hume, arzobispo de Westminster (Inglaterra), 151.

142. Mons. J. G. Calderón, obispo de Cartagena (Colombia), 85.

143. Mons. M. Hermaniuk, arzobispo metropolita de Winnipeg de los Ucranianos, 86.

144. Card. E. Pironio, 142.

145. Card. G. B. Hume, arzobispo de Westminster (Inglaterra), 151.

146. Mons. T. Worlock, relator del Grupo C lengua inglesa, 197; Card. A. Sabattani, relator del Grupo de lengua latina, 202.

147. Mons. M. Magrassi, relator del Grupo de lengua italiana, 201.

148. Mons. T. Tshibangu, relator del Grupo C de lengua francesa, 206.

149. Mons. P. J. Cullinane, obispo de Palmerston North (Nueva Zelanda), 72.

150. Card. P. E. Arns, arzobispo de São Paulo (Brasil), 169; Mons. L. Averkamp, relator del Grupo C de lengua hispano-portuguesa, 207; Mons. A. Zumárraga González, arzobispo coadjutor de Quito (Ecuador), 95; Mons. O. Páez Garcete, obispo de S. Pedro (Paraguay), 160.

151. Mons. A. Zumárraga González, arzobispo coadjutor de Quito (Ecuador), 95. 
Es imprescindible demostrar cómo el pecado se opone a estas aspiraciones humanas de vida, de amor y de libertad, que tienen su propia fuente en Dios ${ }^{152}$.

Este esfuerzo por re-situar el pecado a la luz del amor inefable de Dios creo que responde a un pensamiento expuesto en el aula sinodal por Mons. A. Exner. Opina que se está viviendo en un «ateísmo práctico» y que su «raíz profunda no lo es tanto la pérdida del sentido del pecado, cuanto la pérdida del sentido de Dios. Muchos han perdido el sentido del misterio, el sentido de la santidad y el sentido de la importancia de Dios en la vida» ${ }^{153}$.

Consiguientemente la comunidad cristiana debe considerar el pecado «desde el punto de vista de Dios» con gran seriedad, mientras que el mundo no le concede importancia alguna ${ }^{154}$. Cumplirá fielmente su misión de denunciar el pecado en la medida en que parta de su experiencia bautismal y de la comunión eucarística ${ }^{155}$, en la medida en que discierna el pecado según criterios evangélicos ${ }^{156}$ y lo denuncie valientemente «siguiendo el estilo y la paciencia de Dios: Fuerte y humilde al mismo tiempo, poniéndose siempre como meta la reconciliación en sí misma» ${ }^{157}$.

Por todo ello «la Iglesia que afronta en este Sínodo de manera global y directa, la crisis de la penitencia, debe decir más radical, profunda y determinadamente que la crisis del sentido del pecado está en estrecha relación con una grave crisis del sentido de Dios, de la experiencia de Dios y del modo de vivir de Dios» ${ }^{158}$.

Lo que necesariamente se ha de reconstruir no es tanto el sentido del pecado, cuando el sentido de Dios ${ }^{159}$. Aquel será una consecuencia de éste, sin el cual no se puede suscitar el sentido del pecado. En la predicación debe dominar la preocupación de conducir a los cristianos a una cierta experiencia de Dios amor. Por ello mismo el «Sínodo, en su preocupación por resolver la crisis de la penitencia, debe hacer una presentación solemne, un anuncio, al hombre de hoy, lleno de alegría. El hombre de hoy, oprimido consciente o inconscientemente por su pecado, necesita del anuncio de la gran noticia de Dios como Padre, como amor y misericordia, tal como se nos ha revelado en Cris-

152. Mons. P. G. Cullinane, relator del Grupo A de lengua inglesa, 195.

153. Mons. A. Exner, arzobispo de Winnipeg (Canadá), 96; Mons. A. Quarracino, obispo de Avellaneda (Argentina), 96-7; Mons. V. Mensah, obispo de Porto Novo (Benín), 126.

154. Mons. S. Koto Khoari, obispo de Mohale's Hoek (Lesotho), 159.

155. Mons. M. Magrassi, relator del Grupo de lengua italiana, 201.

156. Mons. F. M. da Costa, arzobispo de Huambo (Angola) 144.

157. Mons. M. Magrassi, relator del Grupo de lengua italiana, 201.

158. Mons. L. León Alvarado, obispo de Huacho (Perú), 146.

159. Mons. A. Exner, arzobispo de Winnipeg (Canadá), 96. 
to. El Sínodo, siguiendo la enseñanza del Santo Padre en la encíclica dives in misericordia, debería dar a esta solemne proclamación pontificia la más amplia y vigorosa resonancia» ${ }^{160}$.

Según monseñor O. Rodríguez para «descubrir el sentido del pecado se hace necesaria una pedagogía del sentido sacramental y del sentido de Dios. Tal pedagogía se apoya en las siguientes actitudes fundamentales: proximidad de Dios; acción constante del Espíritu Santo; fe renovada en la fuerza del Evangelio, como energía transformadora; aceptación positiva del mundo en que vivimos; presencia del misterio de iniquidad; reconocimiento de que la reconciliación en Cristo pasa a través de la comunidad; aceptación de la realidad de que la vida del cristiano alcanza su plenitud cuando es vivida a la luz de la Pascua de Jesús, nacido para la reconciliación y ejemplo de reconciliación» ${ }^{161}$.

No es necesario aludir a la conversión de mentalidad que todo esto está exigiendo a aquellos confesores que se hayan educado en el espíritu de milimetrar los pecados, puesto que admitido que «los criterios clásicos para juzgar el pecado mortal permanecen siendo válidos, sin embargo en la catequesis es más fructuoso poner en evidencia la voluntad salvífica de Dios y su pacto de amor» ${ }^{162}$.

Añádase el recuerdo de que en la denuncia del pecado «se debe subrayar el valor primario e insustituible del testimonio de vida» ${ }^{163}$. El «Sínodo debe recordar a todos los cristianos, pero especialmente a los pastores de almas, la importancia de una vida santa, para el retorno de las ovejas descarriadas...» ${ }^{164}$.

\section{El pecado es egoísmo, un idolatrarse a sí mismo}

El pecado es descrito como «egoísmo y avidez» ${ }^{165}$, como «un espíritu egoísta que determina la vida de la sociedad y de las personas que viven y toman parte en el bien común» ${ }^{166}$, creando así situaciones infectadas por el egoísmo ${ }^{167}$. Por eso «debemos practicar especialmente la reconciliación y la

160. Mons. L. León Alvarado, 146.

161. Mons. O. Rodríguez Madariaga, administrador apostólico de Santa Rosa de Copán (Honduras), 160-161.

162. Mons. L. Monsegwo Pasinya, relator del Grupo B de lengua francesa, 205.

163. Mons. F. M. da Costa, arzobispo de Huambo (Angola), 144.

164. Mons. B. Mve'Engone, obispo de Oyem (Gabón), 99.

165. Mons. S. F. Hamao, obispo de Yôkohama (Japón), 66.

166. P. G. Ferrari, Superior General de los Misioneros Javieranos, 88.

167. P. G. Ferrari, Superior General de los Misioneros Javerianos, 8. 
penitencia por toda forma de egoísmo y por las imperfecciones que podrían impedir que nuestra gente diera respuesta al mandato de Cristo: «Sed perfectos como es perfecto vuestro Padre en los cielos» ${ }^{168}$. La misma guerra no es más que una consecuencia del egoísmo ${ }^{169}$.

Este egoísmo se transforma en un idolatrarse por parte del hombre «moderno y secularizado» que es alérgico a cualquier referencia a un ser superior al que tenga que responder de su conducta ${ }^{170}$; en un convertir al hombre en «artífice de las normas de comportamiento» ${ }^{171}$, en «dueño supremo de su propio destino, único legislador del bien y del mal; juez único de las propias acciones» ${ }^{172}$.

Con esta concepción se relacionan todas aquellas «concepciones de la libertad que atribuyen al hombre el derecho de determinar apriorísticamente valores y normas, o establecer lo que es bueno o malo», siendo así que el verdadero concepto de libertad es aquel que libera al hombre de las ilusiones de una falsa autonomía, mostrándole la posibilidad de recuperar el verdadero estado de hijo de Dios» ${ }^{173}$.

Y hablando del pecado social dicen que «es la negación de la transcendencia y del plan de Dios. Es un ídolo - tener, poder, placer- que determina las relaciones sociales. Es un egoísmo radical que influye su modo de relación en la sociedad y los conduce a la muerte ${ }^{174}$. Se encarna en todos los niveles de la vida: economía, política, ideologías, cultura ${ }^{175}$. Es como una ética de la autosuficiencia ${ }^{176}$.

\section{Es necesario tener una noción personalista del pecado}

En la vida no nos encontramos con pecados, sino con pecadores ${ }^{177}$. El hombre «movido por el Espíritu, va adhiriéndose gradualmente, no tanto a algunas normas y valores morales, cuanto a Dios mismo, como supremo valor y

168. Mons. S. E. Carter, arzobispo de Kignston (Jamaica), 168.

169. P. G. Ferrari, 88 .

170. Card. A. P. Khoraide, patriarca de Antioquía de los Maronitas, 168-169.

171. Card. J. Höffner, arzobispo de Colonia (Alemania), 76.

172. Mons. M. Hermaniuk, arzobispo metropolita de Winnipeg de los Ucranianos, 86.

173. Card. C. M. Martini, 65.

174. Card. P. E. Arns, arzobispo de São Paolo (Brasil), 169.

175. Card. P. E. Arns, arzobispo de São Paolo (Brasil), 169.

176. Card. J. L. Bernardin, arzobispo de Chicago (USA), 171. Mons. E. Wamala, obispo de Kiyinda-Mityana (Uganda), 101: «La Biblia debe ser presentada como un drama continuo entre la obra reconciliadora de Dios con el hombre y no simplemente como una materia académica».

177. Mons. G. E. Santos Ascarza, relator del Grupo C de lengua hispano-portuguesa, 199. 
va configurando totalmente su propio modo de pensar y actuar con la voluntad de Dios.

«De manera opuesta puede ir, poco a poco, adhiriéndose incondicionalmente a algo fuera de Dios, aunque no sea negando formalmente a Dios ni rechazando explícitamente su amor...» ${ }^{178}$.

De aquí que sea necesario tener una concepción dinámica del pecado y reconocer la importancia de la opción fundamental ${ }^{179}$.

El pecado posee un dinamismo interno ${ }^{-180}$, dinamismo que colorea a la acción humana pecaminosa con un carácter histórico, que es necesario subrayar y que "constituiría un buen punto de partida para una teología de las estructuras sociales de pecado" ${ }^{181}$. Tal dinamismo se apoya en la estrecha relación que se establece entre el pecado personal y las tensiones que afligen al hombre: "Ante todo consideramos el estrecho lazo que existe entre el pecado -ética y teológicamente considerado- y el doloroso fenómeno de las dramáticas situaciones y tensiones que afligen a la sociedad actual. También el Concilio Vaticano II afirma esta relación cuando dice que «los desequilibrios que sufre el mundo contemporáneo se relacionan con aquel desequilibrio más profundo y más radicado en el corazón del hombre... que, débil y pecador, no raramente hace aquello que no querría. Por ello sufre una división en sí mismo, de la cual provienen tantas y tan graves discordias en la sociedad (G. et Spes n. 10). La raíz última de las actuales laceraciones de la sociedad es buscada, por tanto, no solamente en el ámbito puramente psicológico y social, sino también, a un nivel más profundo, en el pecado, es decir, en «aquel acto malvado que realiza el hombre libremente delante de Dios y contra Dios, rechazando su amor ${ }^{182}$.

\section{El pecado sólo puede tratarse terapéuticamente}

No pecado-centrismo sino perdón-centrismo: «La reconciliación del hombre con Dios, actuada en el evento de Cristo, representa ciertamente el punto central del Evangelio. Esta realidad, ya ella sola, impide un malentendido de la doctrina cristiana sobre el pecado. Pero es oportuno evidenciar más el genuino y saludable contexto de esta doctrina. De hecho nosotros no creemos en el pecado sino en el perdón de los pecados. Es, pues, necesario, precisa-

178. Card. A. Sabattani, relator del Grupo de lengua latina, 202.

179. Mons. J. M. Santos Ascarza, arzobispo de Concepción (Chile), 86.

180. Mons. S. Naidoo, relator del Grupo B de la lengua inglesa, 195-196.

181. Mons. A. Fernández, arzobispo de Delhi (India), 73.

182. Card. C. M. Martini, 63. 
mente en este tema, subrayar con claridad y coherencia el aspecto cristocéntrico para evitar, desde el principio, toda traza de pecadocentrismo en nuestra enseñanza» ${ }^{183}$.

Para un relanzamiento de la reconciliación y la penitencia conviene dar importancia, en el «proceso de personalización», al aspecto pedagógico y terapéutico del ministerio penitencial de los pastores; subrayar que la reconciliación es portadora de una «energía histórica», capaz de echar los fundamentos para una concreta «cultura del amor» y resaltar el aspecto comunitario de la «paz con la Iglesia» como fuente de vitalidad en la gracia ${ }^{184}$.

Para lograr este tratamiento terapéutico del pecado «urge a nivel científico, un diálogo interdisciplinar más concreto entre la teolgía y las ciencias humanas; $y$, a nivel de praxis, una representación más comprensible del evento «reconciliación y penitencia», también desde el punto de vista lingüístico y celebrativo» ${ }^{185}$.

El mundo actual presenta varias actitudes contrarias a la virtud de la penitencia, como la autosuficiencia que acentúa solamente la realización personal; una tendencia a la privatización de la religión; la negación de valorés absolutos y la ignorancia de las estructuras y de la disciplina religiosa en la búsqueda de significados espirituales. Ante un mundo así configurado la respuesta de «la Iglesia no debe pararse excesivamente sobre el pecado, como si fuese una realidad merecedora de ser tomada en consideradión por sí misma, sino que debe tratar de explicar su realidad como un momento necesario de un proceso mediante el cual el pecador es liberado progresivamente de los lazos del pecado mediante la conversión. Quien está inmerso en el pecado o en situaciones de pecado tiende a ser ciego frente a su estado. A quienes sufren esta situación la Iglesia debe proclamarles la fidelidad y el amor de Dios, la victoria sobre el pecado, vencido por Cristo para ellos, el acceso ilimitado que ahora pueden tener ellos a la gracia recreante de Dios y a una opción diversa del pecado y de la iniquidad, porque todo ha sido hecho posible por el Espíritu de Cristo» ${ }^{186}$.

«La enemistad y la división entre los hombres no son la última palabra, porque la Iglesia tiene la fuerza de la sangre de Jesús que purifica, es decir, con San Agustín «el mundo reconciliado con Dios» indica una situación espiritual existente en la vida humana mediante la cual los hombres alcanzan sú

183. Mons. A. Nossol, obispo de Opole (Polonia), 214.

184. P. E. Viganó, Rector Mayor de los Salesianos, 78.

185. P. E. Viganó, 78.

186. Card. J. L. Bernardin, arzobispo de Chicago (USA), 171. 
reconciliación con Dios y también entre sí. Este misterio tiene su origen en el Padre que reconcilia con Cristo por medio del Espíritu (Lumen Gentium)» ${ }^{187}$.

Por eso los obispos canadienses proponen que el Sínodo se centre en la proclamación del amor y misericordia de Dios a todos los hombres, en promover iniciativas pastorales que ofrezcan experiencias fuertes de fe y que lleven al redescubrimiento del sentido de Dios; centrarse en la proclamación de la «buena nueva» y no en las divisiones ni en el mal ni en el pecado ${ }^{188}$.

\section{Criterio manifestativo del pecado: la dignidad humana}

El grupo A de lengua inglesia sostenía: «Reconocemos que la verdadera humanidad -como nos es revelada en el Evangelio- es el criterio de lo que es justo o equivocado ante Dios». Precisamente la predicación tradicional sobre el pecado, la virtud y la ley no ha tenido mucho impacto porque frecuentemente aparece alejado de las aspiraciones humanas. Es preciso mostrar que el pecado se opone a estas aspiraciones de la vida, de amor y de libertad, que tienen a Dios mismo como fuente» ${ }^{189}$.

«La denuncia profética debe ser clara y ponderar debidamente el bien de la Iglesia y de la humanidad. Debe basarse en la dignidad que tiene el hombre como imagen e hijo de Dios. Su único fin debe ser la paz y la reconciliación».

«En la denuncia, la Iglesia no puede dejarse atrapar por la sed de poder ni por aquellos sistemas y lógicas conflictuales de los que quiere liberar al hombre» ${ }^{190}$.

«El movimiento de reconciliación que el Sínodo quisiera poner en acto no se refiere únicamente a los cristianos. Todo hombre, sea cual fuere su cultura y religión, debe elegir diariamente entre una actitud de apertura o de clausura frente a los demás. En esta elección se pone en relación con Dios, como testimonia la parábola del juicio en Mateo...» ${ }^{191}$.

«La Iglesia realiza su ministerio de reconciliación proclamando y promoviendo la justicia, la paz y el amor para con todos; animando el desarrollo integral del hombre; promoviendo los mejores valores culturales de los varios pueblos, especialmente el sentido de lo sagrado...» ${ }^{192}$.

«Desde el punto de vista de los pobres y de los humildes, la perspectiva

187. Card. J. C. Aramburu, arzobispo de Buenos Aires (Argentina), 79.

188. Mons. A. Exner, arzobispo de Winnipeg (Canadá), 96.

189. Mons. P. G. Cullinane, relator del Grupo A de lengua inglesa, 195.

190. Mons. L. Monsegwo Pasinya, relator del Grupo B de lengua francesa, 206.

191. Mons. G. Teissier, arzobispo coadjutor de Argel, 95.

192. Mons. J. Spaita, obispo de Mansa (Zambia), 98. 
del documento final debe subrayar la relación con el Reino de Dios e incluir el pleno desarrollo humano y la paz mundial» ${ }^{193}$.

«En la celebración conclusiva del Concilio Vaticano II, el Papa Pablo VI pidió a la Iglesia que reconociera a Cristo y al Padre en el rostro sufriente de la humanidad. Hoy este rostro está desfigurado por el sufrimiento del fracaso de tantos matrimonios, por la desocupación, por la discriminación racial, por los conflictos industriales, por la violencia, por la represión y el terrorismo.

«La Iglesia debe condividir los sufrimientos humanos y trabajar por una solución de los conflictos y por la reconciliación de los pueblos. De esta manera acerca a los pueblos entre sí y reconocen que la reconciliación viene solamente de Dios».

«La lucha común por la justicia social hace descubrir a los cristianos sus vínculos de unidad y su necesidad de reconciliación».

«La búsqueda de la justicia social y de la paz lleva a desear la reconciliación con Dios y prepara el camino hacia el sacramento. Son las necesidades, reales y psicológicas en continuo cambio, las que han conducido el desarrollo, a lo largo de los siglos, de la actual forma con que se celebra el sacramento. El camino que conduce al hombre de hoy hacia Dios pasa a través del corazón humano con sus complejos deseos, temores, alegrías y sufrimientos. Creo que este es el mejor camino para lograr que el hombre comprenda su necesidad de reconciliación con Dios a través del sacramento de la reconciliación» ${ }^{194}$.

\section{Pecado y opción fundamental}

Son relativamente numerosas las alusiones a la opción fundamental, reflejando las diversas tendencias.

La tendencia que pudiéramos llamar contraria a la opción fundamental no suele manifestar explícitamente su oposición, sino sólo implícitamente en cuanto que sigue defendiendo la validez de los criterios clásicos. Así el grupo $B$ de lengua francesa afirma, sin citarla explícitamente, pero teniéndola en la mente: «Los cristerios clásicos en cuanto a la determinación del pecado mortal siguen manteniendo su validez. Pero en la catequesis es más fructuoso evidenciar la voluntad salvífica de Dios y su pacto de amor» ${ }^{195}$.

Algunas intervenciones parecen aceptarlas implícitamente. Así monseñor

193. Mons. A. Fernández, arzobispo de Delhi (India), 73.

194. Mons. D. Worlock, arzobispo de Liberpool (Inglaterra), 68-69.

195. Mons. L. Monsengwo Pasinya, relator del Grupo B de lengua francesa, 205. 
Ricardo Vidal después de haber subrayado la importancia de la formación de la conciencia, sostiene que en la determinación del pecado mortal y venial «ha de ponerse énfasis en la intención y en las circunstancias, en contraposición con el juzgar la gravedad de un acto a partir de los resultados y de sus consecuencias» ${ }^{196}$. En el mismo sentido creo que deban interpretarse las palabras de monseñor Oscar Paz, quien entre los valores descuidados enumera «el sentido, significado, contenido y la malicia del pecado» y propone como norma de vida la «vocación de la persona humana según el plan de Dios y su misión en el mundo». «En este sentido es necesario seguir las directrices del Vaticano II en la Gaudium et Spes, especialmente cuando se refiere al modo dinámico e histórico de considerar la vida y la misión del hombre en el mundo. En esta perspectiva el pecado es la negación, oposición o destrucción de este plan, de esta misión» ${ }^{197}$.

Uno de los defensores más decididos de la opción fundamental es monseñor J. Spital. Señala la «concepción demasiado objetivista de los pecados graves y leves», como «una de las causas fundamentales de la disminución de la práctica de la penitencia». Y si esto es verdad «se impone una reflexión intensa para dar un nuevo aliento a la catequesis y a la práctica de la penitencia. Se ha de hablar insistentemente de las opciones fundamentales del hombre... Desde esta perspectiva sería muy oportuno que antes de distinguir los pecados en graves y veniales se introdujera el concepto de «pecado por causa del estilo de vida» (Lebensführung-Schuld). Porque muchas personas afirman no haber pretendido tomar posición frente a Dios, sino que se dejaban llevar orientando su vida según los criterios de este mundo. Estas excusas han de tomarse en consideración».

«Solamente con la introducción de este concepto, se podrá decir que existen acciones en las cuales la opción fundamental se explicita más o menos. En esta óptica pueden dividirse las acciones en graves y veniales. Prácticamente se trata de acciones cuya iniquidad sólo puede conocerse sabiendo si concretamente expresan o no una opción fundamental» ${ }^{198}$.

«El esquema presenta en pocas páginas una síntesis notable de los principales problemas morales con una concepción dinámica del pecado y reconoce la importancia de la opción fundamental» ${ }^{199}$.

Causa satisfacción que el cardenal Sabattani aplique el término de opción fundamental a la justificación y a la determinación del pecado mortal: «El

196. Mons. D. J. Ryan, obispo de Dublín (Irlanda), 91.

197. Mons. O. Páez Garcete, obispo de S. Pedro (Paraguay), 160.

198. Mons. H. J. Spital, obispo de Trier (Alemania), 177-178.

199. Mons. J. M. Santos Ascarza, arzobispo de Concepción (Chile), 86. 
hombre, movido por el Espíritu, llega gradualmente a adherirse, no tanto a algunas normas y valores morales, cuanto a Dios mismo como sumo valor y a conformar totalmente su propio modo de pensar y de actuar con la voluntad de Dios.

«De manera opuesta el hombre puede, poco a poco, centrarse incondicionalmente en algo fuera de Dios, aun no negando formalmente a Dios y no rechazando explícitamente su amor. En tal caso peca gravemente y destruye en sí la vida del Espíritu (pecado grave o mortal), mientras que, en otras circunstancias, adopta por fragilidad, un comportamiento de indiferencia hacia el Señor (pecado venial)...».

«La justificación, que se actúa en un momento con una opción fundamental orientativa de la persona, es precedida por un desarrollo progresivo que, iniciado al menos con el amor perfecto, tiende a su desarrollo definitivo"».

«De manera opuesta, el hombre, si no combate sus inclinaciones desordenadas, puede dar a la propia existencia una orientación negativa frente a Dios. La misericordia infinita del Padre le ofrece, por amor, la posibilidad de la reconciliación y de la plena purificación mediante el sacramento y el ejercicio de una auténtica penitencia alargada durante toda la vida en vistas de la perfecta comunión con Dios y con los hermanos» 200.

Monseñor M. Magrassi comprende que, aun manteniendo la clásica división bipartita del pecado en grave o mortal y venial «parece que la categoría de la opción fundamental, rectamente interpretada, puede ayudar a comprender la incidencia de cada pecado en la vida del creyente» ${ }^{201}$.

Mons. J.M. Santos Ascarza nos da la interpretación de un padre sinodal: «El esquema presenta en pocas páginas una notable síntesis de los principales problemas de teología moral, con una concepción dinámica del pecado y reconoce la importancia de la opción fundamental. Sería conveniente enunciar algunos principios que eviten caer en el relativismo moral» ${ }^{202}$.

Finalmente tampoco faltan intervenciones sinodales que definen el pecado en función de la opción fundamental: «Según la S.E. y la Iglesia antigua, el pecado mortal del bautizado es ciertamente posible, pero excepcional». El pecado mortal «es un cambio de la opción fundamental del hombre contra Dios y contra el amor» ${ }^{203}$.

200. Card. A. Sabattani, relator del Grupo de lengua latina, 202.

201. Mons. M. Margrassi, relator del Grupo de lengua italiana, 201.

202. Mons. J. M. Santos Ascarza, 86.

203. Mons. S. F. Hamao, obispo de Yokohama (Japón), 170. 


\section{División del pecado en conexión con la opción fundamental}

La mayor parte de los padres sinodales permanece anclada en la tradicional división bipartita del pecado: mortal y venial ${ }^{204}$.

Entre los restantes padres sinodales se constata un cierto escalonamiento en el abrirse a una división tripartita del pecado. Unos siguen defendiendo la división bipartita, pero su distinción se obtendrá como resultado del criterio de la opción fundamental ${ }^{205}$. Otros expresan la necesidad de «una cuidadosa investigación teológica sobre la posibilidad de establecer una tercera categoría entre el pecado mortal y el venial. Sería el pecado «grave». Tal categoría de «grave» incluiría todas aquellas faltas morales que versaran sobre materia grave, pero sin embargo, no constituyeran una ruptura radical de nuestra relación fundamental con Dios. Entre los factores que empujan en favor de esta nueva categoría se cuenta la teoría de la opción fundamental» ${ }^{206}$. También el grupo A de lengua francesa enumera, entre las aclaraciones que son totalmente necesarias, la de precisar «la distinción entre el pecado venial y el mortal, particularmente la idea de la opción fundamental, la eventualidad de una distinción ternaria del pecado: mortales, graves y veniales, y los medios pastorales para explicar estas nociones» ${ }^{207}$.

Hay quienes conocen la división tripartita del pecado tal como es expuesta desde ya hace años, por los moralistas, pero se oponen a ella no tanto por la división en sí misma, cuando por la falta de claridad en las definiciones que se dan de la misma. Se tiene la impresión de que solamente aceptarán un patrón matemático, exacto, que permitiera concluir a toda persona, aun a las ajenas al mismo pecador, con gran seguridad: tú, aquí has pecado mortalmente y aquí no. Sin duda se contradicen, puesto que estos mismos afirman que «en la vida no nos encontramos con pecados, sino con pecadores». Si esto es así, la decisión de afirmar o negar si ha habido pecado o no, corresponde al propio pecador, en última instancia. Desde fuera solamente podremos constatar que ha violado o no un valor importante o no tan significativo. He aquí sus afirmaciones literales: «el pecado es la ruptura de la alianza con Dios, de la cual Cristo es imagen visible.

204. Mons. F. Francić, arzobispo de Split-Makarska (Yugoslavia), 90; Mons. R. Vival, arzobispo de Cebú (Filipinas), 91; Mons. R. Stecher, obispo de Innsbruck (Austria), 122-123; Mons. M. I. Lubachivsky, 190; Card. C. M. Martini, 191-192; Mons. M. Magrassi, relator del Grupo de lengua italiana, 201; Card. A. Sabattani; relator del Grupo de lengua latina, 202; Mons. L. Monsengwo Pasinya, relator del Grupo B de lengua francesa, 205; Mons. A. López Trujillo, arzobispo de Medellín (Colombia), 216; Card. J. Ratzinger, 138.

205. Mons. H. J. Spital, obispo de Trier (Alemania), 177-178.

206. Mons. S. Naidoo, relator del Grupo B de lengua inglesa, 196.

207. Card. G. Danneels, relator del Grupo A de lengua francesa, 204. 
«No siempre la claridad de los manuales en el considerar objetivamente el pecado como pecado mortal, grave o venial se encuentra también en la vida, porque en la vida nos encontramos no con el pecado, sino con el pecador. El pecado grave opera un rechazo total de Dios, porque el pecador se pone fuera de él con una opción considerada fundamental» ${ }^{208}$.

Algunos parecen negar todo valor a una distinción tripartita del pecado: «Los pecados que rompen la relación con Dios son más graves y mortales. También los pecados que dependen de la debilidad pueden ser de hecho graves y mortales. Todos los pecados graves o mortales deben ser sometidos al poder de las llaves de la Iglesia» ${ }^{209}$. Finalmente nos encontramos con aquellos que sostienen decididamente «la necesidad de dividir el pecado en venial, grave y mortal puesto que, no siempre la situación de pecado lleva consigo la destrucción de la relación con Dios. El pecado mortal es el que rompe la relación con Dios, lo cual no siempre ocurre con el pecado grave. Y esta distinción debe hacerse puesto que parece que el Sínodo quiere dar vitalidad a la absolución general como medio normal de la Iglesia para perdonar los pecados» ${ }^{210}$.

\section{Consecuencias}

1. Debemos de preocuparnos de preparar debidamente a los niños para la confesión y de que tengan experiencias de la misma. Pero «en este caso no se trata de pecados graves (en el sentido de mortales), sino de una praxis motivada por razones pedagógicas y psicológicas» ${ }^{211}$.

2. Los pecados graves —-según la división tripartita del pecado: venial, grave y mortal- no impondrían forzosamente la confesión individual. No entran a juzgar los efectos positivos o no de una confesión individual, pero no la exigirían imperiosamente ${ }^{212}$.

3. Partiendo de la concepción del pecado en sí mismo y de su relación con la opción fundamental concluyen manifestando un cierto descontento ante los catálogos tradicionales del pecado, aunque por diversas razones:

a) Rigorismo injustificado: «Cuando se profundiza en la búsqueda de las

208. Mons. G. E. Santos Ascarza, relator del Grupo C de lengua hispano-portuguesa, 199.

209. Mons. F. Franić, arzobispo de Split-Makarska (Jugoslavia), 90.

210. Mons. U. Cerasuolo Stacey, obispo auxiliar de Guayaquil (Ecuador), 128.

211. Mons. J. Landázuri Ricketts, arzobispo de Lima (Perú), 75.

212. Card. S. Pappalardo, arzobispo de Palermo (Italia), 132: «Se propone la hipótesis que permita a la Iglesia instituir para los pecados de menor entidad otras formas de celebración, con carácter sacramental, no ligadas a la confesión de los pecados, pero sí expresivas del arrepentimiento y del propósito de enmienda»... «Debería confeccionarse una lista taxativa de los pecados capitales. Para éstos seguiría en vigor la actual disciplina...». 
causas de la crisis general del sacramento de la confesión, hay que subrayar que el rigorismo existente en ciertos aspectos de la llamada teología tradicional no está exento de responsabilidad en cuanto a la deplorable confusión de las conciencias. El deconsiderado y frecuente uso de la palabra «sub gravi», que era empleada con el significado de «obligatorio bajo pena de pecado mortal», ha conducido a la multiplicación de los pecados «graves» objetivos. Resultados similares ha tenido la enseñanza sobre el sexto mandamiento, cuyos pecados, todos sin excepción, eran considerados graves «ex todo genere suo». Esta exasperación ha contribuido a dar origen al extremo laxismo de nuestros días y al indiferentismo. Es imprescindible que la moral se clarifique en estos puntos» ${ }^{213}$.

b) Son listas alejadas de las aspiraciones humanas: «la manera de predicar sobre el pecado, la virtud y la ley no han tenido mucho impacto, porque frecuentemente aparecían «desligadas de las aspiraciones humanas. Es necesario mostrar cómo el pecado se opone a esta aspiración de vida, de amor y de libertad, que tienen su origen en Dios» ${ }^{214}$.

c) Ignorancia de la diversidad de culturas, en sus posiblidades de vehículos aptos para transmitir el contenido teológico del pecado ${ }^{215}$

d) Finalmente, tales listas no dicen nada precisamente a los jóvenes y a los cristianos comprometidos: "Ante todo condividimos nuestra alegría porque el número de fieles que se acercan al sacramento es numeroso en muchas de nuestras diócesis, pero también condividimos nuestra preocupación porque muchos jóvenes y la élite se alejan de la práctica del sacramento. Lamentan que la enumeración tradicional de los pecados, como la han aprendido en el catecismo, no les ofrezca interés alguno. Afirman que no aciertan a descubrir en el confesor el padre con el cual poder discutir sus problemas y capaz de ver los pecados en el contexto de su vida» ${ }^{216}$.

4. Correlativamente han expresado el deseo de formular nuevas listas de pecados

El card. Pappalardo no duda en afirmar que «se debería componer una

213. Mons. R. Stecher, obispo de Innsbruck (Austria), 122-123.

214. Mons. T. Tshibangu, obispo auxiliar de Kinshasa (Zaire), 84; P. E. Viganó, Rector Mayor de los Salesianos, 78.

215. P. E. Viganó, 80 .

216. Mons. J. Babatunde Adelakun, obispo de Oyo (Nigeria), 82-83. 
lista taxativa de los pecados capitales para los cuales continuaría en vigor la actual disciplina, hasta exigiéndose que la eventual separación necesaria sea siempre consistente, seria y se lleve a cabo antes de la absolución» ${ }^{217}$. Igualmente los obispos del Chiad «consideran deseable la compilación de una lista de errores cuya materia debe considerarse grave» ${ }^{218}$.

Pero no se trata de sustituir unas listas por otras. Las nuevas listas deben componerse:

1. Libres de la tendencia al «uso desconsiderado» del adjetivo «mortal» de manera que su equilibrio y rectitud, al contrario que la exasperación cuantitativa del número de pecados mortales, sea la mejor arma contra el laxismo y el indiferentismo ${ }^{219}$.

2. No será una reproducción o retorno «a las nociones y a las categorías simplicistas del pecado», ya habituales ${ }^{220}$.

3. Partirán de la aceptación de la «verdadera humanidad, tal como nos es revelada en el Evangelio, como criterio de lo que es justo o equivocado ante Dios»... de manera que se muestre claramente que «el pecado se opone a las aspiraciones de vida, de amor y libertad, que tienen su fuente en Dios mismo» y así, la gente «pueda reconocer el pecado en su propia vida y también la necesidad del perdón» ${ }^{221}$. Recogerán todos los conflictos del mundo actual - variando según vayan surgiendo unos y desapareciendo otros. Identificados así, abstractamente, los pecados desde la óptica de la dignidad humana y del ideal cristiano de justicia ${ }^{222}$, pasará a denunciarlo en cualquiera de sus expresiones personales o estructurales ${ }^{223}$. Tales concretizaciones del pecado tenderán a defender, sobre todo, a los más necesitados y a favorecer el esfuerzo por la justicia

3. y la paz ${ }^{224}$.

4. Unas listas que dejen la puerta abierta a la diversidad de culturas, de

217. Card. S. Pappalardo, arzobispo de Palermo (Italia), 132.

218. Mons. Ch. Vandame, arzobispo de N'Djamena (Chiad), 136.

219. Mons. R. Stecher, obispo de Innsbruck (Austria), 122-123.

220. Mons. P. G. Cullinane, relator del Grupo A de lengua inglesa, 195.

221. Mons. P. G. Cullinane, relator del Grupo A de lengua inglesa, 195; Card. J. Bernardin, arzobispo de Chicago (USA), 212: «Y es que los cristianos esperan algo más, y no menos, de lo que les prometen las ideologías». «Esperan un nuevo Reino en el que Dios será todo en todos, en el que la muerte será superada por la resurrección. Esperan que cuanto de vil y equivocado hay en cada relación, será ajustado de una vez para siempre. Esta esperanza sostiene el compromiso que mira hacia la reconciliación en nuestro mundo. Mostremos claramente cuanto puede ayudar el sacramento de la reconciliación para sostener los esfuerzos de los hombres de hoy».

222. Mons. F. Sebastián Aguilar, obispo de León (España), 121.

223. Mons. M. Magrassi, relator del Grupo de lengua italiana, 201.

224. Card. A. Lorscheider, arzobispo de Fortaleza (Brasil), 183-184. 
manera que el pecado al igual que «los problemas morales y sociales no sean considerados exclusivamente desde una óptica europea...» ${ }^{225}$.

5. Tampoco deben olvidar que «al presentar la verdad objetiva y los valores objetivos, no debemos descuidar de mostrar nuestra conciencia de los factores subjetivos, que actúan en el proceso de asimilación de los valores y de la verdad objetiva por parte de la gente. Es necesaria cierta gradualidad» ${ }^{226}$.

«El sínodo debería dedicar todas sus fuerzas, particularmente las discusiones de grupo, a desarrollar una celebración digna del nombre de este sacramento. Esta celebración debería ser capaz de hacer retornar a los pecadores a la casa del Padre de la misericordia, como hijo pródigo. Abramos las puertas para que se desarrollen nuevos modos de celebración sacramental. Al hacerlo tengamos nuestros ojos abiertos sobre aquellos que se acercan a este sacramento a su edad, a su cultura, a sus tiempos y a su formación y madurez moral e intelectual. Hay que evidenciar el modo de la celebración» ${ }^{227}$.

Algunos Padres sinodales llegan a conclusiones más radicales, partiendo de la opción fundamental. Por primera vez hemos podido oír, en un aula tan representiva de la comunidad eclesial, gracias a Dios, que se ha hecho «un uso abusivo y frecuente de la palabra «sub gravi», entendida en el sentido de «obligatorio bajo pena de pecado mortal», lo que ha conducido, como consecuencia, a la multiplicación de los pecados «objetivos» graves... Similares resultados ha dado la enseñanza sobre los pecados contra el sexto mandamiento, catalogados «ex toto genere suo graves». Esta exasperación ha contribuido a causar un laxismo extremo y un indiferentismo. Es urgente, pues, que la teología moral se clarifique en estos puntos» ${ }^{228}$.

Denunciado así el excesivo rigorismo en la confección de las listas de los pecados graves, se necesitaba poco para dar el paso ulterior, que monseñor S. F. Hamao, obispo de Kokohama (Japón), expone así: «Un segundo punto que quisiera tomar en consideración es la naturaleza del pecado mortal en general. Según la Escritura y la Iglesia antigua, el pecado mortal del bautizado ciertamente es posible pero es excepcional. Es un cambio de la opción fundamental del hombre volviéndose contra Dios y contra el amor. Por eso debemos suponer que la gran mayoría de nuestros fieles, que frecuentan la misa, no han cometido un pecado mortal. Pero, sin embargo, tienen necesidad de una plena conversión, sobre todo en lo referente a los pecados sociales; y también sus pecados veniales deben ser borrados. Dada esta situación ¿no sería

225. Card. J. Höffner, arzobispo de Colonia (Alemania), 75.

226. Mons. P. G. Cullinane, relator del Grupo A de lengua inglesa, 195.

227. Mons. L. Kanene Obiefuna, obispo de Awka (Nigeria), 107.

228. Mons. Mons. R. Stecher, obispo de Innsbruck (Austria), 123. 
deseable introducir nuevas formas de celebración del sacramento de la reconciliación, concluidas con una absolución general? Obviamente quedaría la obligación de confesar los pecados mortales ciertos y se debería continuar animando siempre a la confesión privada de los pecados veniales» ${ }^{229}$.

Varios obispos americanos presentaban el mismo pensamiento, pero en forma de interrogante: «Muchos obispos de los EE. Unidos sostienen que el descenso de la frecuencia del sacramento de la reconciliación depende en parte de la confusión sobre lo que constituye el pecado grave, sobre qué pecados deben ser confesados y sobre si el pecado mortal es cosa muy rara» ${ }^{230}$.

La afirmación de monseñor Hamao y la pregunta de los obispos americanos debieron impresionar al aula sinodal, porque el cardenal Martini, en su relación del 30 de octubre de 1983, la puntualizaba con las siguientes palabras: «El pecado grave, que compromete en su raíz la comunión con el Padre y con los hermanos es acontecimiento por su naturaleza excepcional, pero no necesariamente raro. El cuarto sacramento, del que se ocupa el presente Sínodo, se ocupa y provee a tal eventualidad» ${ }^{231}$.

\section{MINISTRO DE LA RECONCILIACIÓN}

Las intervenciones sinodales describen la situación con frases bastante doloridas. Aluden a profesores que «en desacuerdo con la doctrina de la Iglesia, no consideran la escucha de las confesiones individuales como una parte praecipua de la misión sacerdotal» ${ }^{232}$; recuerdan la insuficiencia de confesores ${ }^{233}$; enumeran, entre las causas de la disminución de la frecuencia de la confesión, «la negligencia de los sacerdotes en administrarlo, porque piensan que las confesiones son un hecho rutinario y no expresión de una verdadera

229. Mons. S. F. Hamao, obispo de Yokohama (Japón), 170.

230. Mons. A. B. Vaughan, obispo auxiliar de New York (USA), 105

231. Card. C. M. Martini, 191-192.

232. Mons. I. M. de Orbegozo y Goicoechea, obispo de Chiclayo (Perú), 173: «Deben proveerse cursos de formación permanente para el clero, que sirvan para resolver las cuestiones reales, no para suscitar dudas o divulgar hipótesis teológicas más o menos aventuradas. Deben estar organizados con claro sentido pastoral para ayudar a los confesores a desarrollar su misión cada vez más de acuerdo con la enseñanza oficial de la Iglesia, como ministros suyos que son. Éstos criterios también son válidos en cuanto a la elección de los profesores de dichos cursos, conscientes de que no serían buenos maestros aquellos que, en desacuerdo con la Iglesia, no consideraren como una parter paecipua de su misión sacerdotal la escucha de las confesiones»y.

233. Mons. R. Gay, Superior General de los Misioneros de África, 123; Mons. M. Luzardo Romero, obispo de Ciudad Guayana (Venezuela), 180; Mons. T. Tshibangu, relator del Grupo C de lengua francesa, 207. 
conversión» ${ }^{234}$, porque «no creen suficientemente en el sentido o en el valor del sacramento».... ral han causado una cierta desorientación en los sacerdotes, especialmente en los más ancianos, y como consecuencia «también los fieles sufren cierta desorientación» ${ }^{236}$; han constatado que, «tanto a sacerdotes como a fieles, les falta la claridad necésaria para distinguir los pecados graves en los casos individuales») ${ }^{237}$.

Quienes generosamente se prestan al servicio pastoral de la administración de este sacramento merecen todos los elogios ${ }^{238}$. Pero el Sínodo no se conforma con tales elogios. Aunque sin hacerlo sistemáticamente, subraya algunos trazos fundamentales que puedan delinear la figura del confesor.

\section{Hombre de fe: convencido del sentido y del valor del sacramento}

«Si hay crisis del sacramento de la reconciliación en parte se debe al hecho de que se da una crisis de confesores, es decir, a que algunos sacerdotes no creen suficientemente en el sentido y en el valor de este sacramento, o no se hacen disponibles para la administración de este sacramentos» ${ }^{239}$; «quizás el problema de la Iglesia de hoy sea la falta de fe...» ${ }^{240}$.

En cambio «un buen confesor debe ser hombre de fe. Debe tener fe en los misterios salvíficos que celebra» ${ }^{241}$. «No es posible lograr progreso alguno sin atacar directamente al egoísmo, a la avaricia y tanto menos sin el descubrimiento personal del valor del sacramento de la reconciliación tanto a nivel individual como comunitario» ${ }^{242}$. «Nosotros, ministros del sacramento de la reconciliación, obispos y sacerdotes, necesitamos conocer el sentido del sacra-

234. Mons. M. Luzardo Romero, obispo de Ciudad Guayana (Venezuela), 180.

235. Mons. T. Tschibangu, relator del Grupo C de lengua francesa, 207.

236. Mons. G. E. Santos Ascarza, relator del Grupo C de lengua hispano-portuguesa, 199; Mons. T. Tshibangu, obispo auxiliar de Kinshasa (Zaire), 83: «La crisis de «confesores»: Hemos de señalar la insuficiencia del número efectivo de sacerdotes para asegurar normalmente la penitencia individual; por otra parte, dada la situación actual general de la investigación teológica sobre el sentido, la importancia y la práctica de este sacramento, un número, cada vez mayor, de sacerdotes no sabe qué actitud pastoral adoptar en este punto».

237. Mons. J. Wanke, administrador apostólico de Eerfurt-Meiningen (Berlín), 89.

238. Card. O. Rossi, 236: «Hemos de elogiar a muchos que se prestan generosamente a la administración de este sacramento. Sin embargo es necesario que se les ofrezca una preparación más profunda en el campo teológico, espiritual y antropológico. Quizás hubiera que hacer más rígidos los criterios para admitir a un sacerdote a la administración de este sacramento».

239. Mons. T. Rshibangu, relator del Grupo C de lengua francesa, 207.

240. Mons. W. Ch. Tumi, arzobispo coadjutor de Garoua (Camerún), 84.

241. Mons. W. Ch. Tumi, 84.

242. Mons. M. J. Conti, obispo de Aberdeen (Escocia), 154. 
mento que se nos ha confiado. El sacramento de la reconciliación es una buena nueva decisiva. Nos dice que el amor de Dios es más fuerte que el pecado, que nada se ha perdido definitivamente, que la historia no es fatalidad, que el hombre puede nuevamente ser hijo de Dios... ${ }^{243}$. Hemos de conocer el sentido del sacramento de manera que no lo relativicemos considerándolo como un medio, entre tantos, de reconciliación y como un gesto que Dios sobreañade a los esfuerzos humanos para sacralizarlos y darles plenitud ${ }^{244}$.

Una fe que invita al sacerdote a «incluirse a sí mismo entre los necesitados de reconciliación» ${ }^{245}$, a «ponerse en situación de pecador ante la misericordia divina, más que en actitud de juez sobre los pecados. Esta identificación es el significado del sacerdocio de Cristo y de nuestra comparticipación en él» ${ }^{246}$.

Sin la conversión interior no podrá realizar la verdadera denuncia profética ni podrá crear una comunidad reconciliada «si el corazón del sacerdote no se ha reconciliado antes con Dios y con los hombres» ${ }^{247}$. Y es que «nada puede sustituir a la santidad de un confesor. Los laicos lo aprecian como la cualidad más atrayente del ministro de la penitencia» ${ }^{248}$.

Una fe que le permite valorar la celebración del sacramento de la reconciliación como una parte praecipua de su misión sacerdotal ${ }^{249}$, de manera que la «reconciliación ocupe el puesto central del ministerio sacerdotal» ${ }^{250}$, puesto que se siente «responsable de la eficacia del sacramento de la reconciliación como se nos dice en la 2 Cor 5, 18-20 y valora «el deber de oír las confesiones de los fieles como su preocupación prioritaria» ${ }^{251}$. Claro que lo entiende en un sentido amplio, ya que «la Iglesia realiza el ministerio de la reconciliación a través de los sacerdotes, que llevan a cabo esta misión mediante la predicación y la celebración de los sacramentos, especialmente del bautismo, de la confesión y del consejo» ${ }^{252}$.

243. Mons. F. Favreau, obispo de Naterre (Francia), 180; Mons. J. de Jesús Pimiento Rodríguez, arzobispo de Manizales (Colombia), 189-190; Mons. G. Singha, obispo de Owando (Congo): «El Sínodo debe insistir en que los sacerdotes sean mejor formados y sensibilizados en el valor de este ministerio».

244. Mons. R. Coffy, arzobispo de Albi (Francia), 114

245. Mons. R. Coffy, 144; Mons. A. Mabutas y Llorén, arzobispo de Davao (Filipinas), 133: «En cuanto al modo pastoral de afrontar el problema debemos conseguir que la mentalidad de reconciliación comience por nosotros mismos...».

246. Card. S. Kim, arzobispo de Seoul (Corea), 85.

247. Card. J. L. Sin, arzobispo de Manila, 170.

248. Mons. W. Ch. Tumi, arzobispo coadjutor de Garoua (Camerún), 84.

249. Mons. I. M. de Orbegozo y Goicoechea, obispo de Chiclayo (Perú), 173.

250. Mons. T. Worlock, relator del Grupo C de lengua inglesa, 197; Mons. B. Mve'Engone, obispo de Oyem (Gabón), 99; Card. J. L. Sin, arzobispo de Manila, 170-1.

251. Mons. E. Wamala, obispo de Kiyinda-Mityana (Uganda), 101.

252. Mons. W. Ch. Tumi, arzobispo coadjutor de Garoua (Camerún), 84. 
Cuando todo esto lo vive de verdad, entonces «la vida de un sacerdote, fiel a las exigencias de su vocación, es ya una invitación persuasiva para que sus fieles se acerquen al sacramento de la reconciliación» ${ }^{253}$.

\section{Hombre de fe: hombre de confesión frecuente}

«El sacerdote debe dar ejemplo a los fieles en la práctica de la confesión frecuente» ${ }^{254}$, «debe frecuentar él mismo el sacramento de la reconciliación para ser capaz de animar a los demás a hacer lo mismo, y quizás nuestros sacerdotes no se acercan frecuentemente a la confesión» ${ }^{255}$.

Para formarse con miras al ministerio del sacramento de la reconciliación «seminaristas y sacerdotes, deben ser, en primer lugar, buenos penitentes» ${ }^{256}$, porque «el sacerdote confiesa, como se confiesa» ${ }^{257}$.

La frecuente celebración de este sacramento no solamente ayudará al confesor a profundizar cada vez más en su conversión, sino que también le dará una mayor disponibilidad en el servicio de los fieles ${ }^{258}$.

Las intervenciones sinodales insisten en la disponibilidad del sacerdote para la celebración de este sacramento. Unas veces lo hacen lamentando su falta, tanto desde el punto de vista material como anímico ${ }^{259}$; otras lo hacen urgiendo a los sacerdotes para que creen en sí mismos dicha actitud positiva y práctica. Se llega a utilizar un lenguaje recio: «Se recuerde a los sacerdotes que están obligados a recibir las confesiones sacramentales, a las cuales los fieles tienen derecho» ${ }^{260}$.

Se desea una disponibilidad activa que, por una parte, sepa renunciar a

253. Mons. W. Ch. Tumi, 84.

254. S.B.R.G.G. Beltritti, patriarca latino de Jerusalén, 69; Card. G. Danneels, relator del Grupo A de lengua francesa: «No habría que cargar toda la responsabilidad de la crisis sobre los sacerdotes. Las causas son mucho más complejas. En cuanto a la preparación de los ministros, es importante educar a los futuros sacerdotes y que ellos mismos practiquen el sacramento...».

255. Mons. W. Ch. Tumi, 84; Mons. P. F. Flores, arzobispo de San Antonio (USA), 115.

256. Mons. D. Castrillón Hoyos, relator del Grupo A de lengua española, 198.

257. S.B.R.G.G. Beltritti, patriarca latino de Jerusalén, 69.

258. Mons. I. M. de Orbegozo y Goicoechea, obispo de Chiclayo (Perú), 173; Mons. P. F. Flores, obispo de S. Antonio (USA), 115; Mons. A. Perraudin, arzobispo de Kabgayi (Rwanda), 68: «Los obispos insisten en la disponibilidad de los sacerdotes y en la formación de los candidatos al sacerdocio a luz de esta perspectiva».

259. Mons. M. F. Fernando, obispo de Chilaw, 110; Mons. L. Monsengwo Pasynia, obispo auxiliar de Kisangani (Zaire), 108; Mons. A. Mabutas y Lloren, arzobispo de Davao (Filipinas) 133; Mons. G. Sigha, obispo de Owando (Congo), 147; Mons. T. Tshibangu, relator del Grupo C de lengua francesa, 207.

260. Card. J. Landázuri Ricketts, arzobispo de Lima, 74 Mons. P. F. Flores, arzobispo de San Antonio (USA), 115; Mons. P. F. Flores, arzobispo de San Antonio (USA), 115; Mons. A. Perraudin, arzobispo de Kabgayi (Rwanda), 68. 
otras muchas actividades, buenas y dignas en sí mismas, pero que pueden ser confiadas a los laicos, para dedicarse, según un recto criterio de prioridades, a aquella misión sacramental que solamente el sacerdote puede desempeñar; como son la eucaristía y el sacramento de la reconciliación ${ }^{261}$. Por otra parte tal disponibilidad activa compromote al sacerdote a cuidar el servicio pastoral de la reconciliadión sacramental de tal manera que facilite en lo posible la «ya de por sí fatigosa respuesta del creyente a la misericordia divina» y le ayude a dar una respuesta auténtica y eficaz ${ }^{262}$.

No puedo omitir la especial atención que presta a los enfermos ${ }^{263}$.

\section{Profeta de la denuncia}

«El pastor debe ser un «profeta de la denuncia» ${ }^{264}$. «El anúncio del Evangelio y la denuncia de cuanto le contradice forman parte integrante de su misión» ${ }^{265}$.

Pero denuncia inspirada en el Evangelio, sin contaminaciones ideológicas ${ }^{266}$. «La norma de la acción de los cristianos por la justicia lo es el Evangelio y no ideología alguna» ${ }^{267}$. «El juicio final de Dios, la vida resucitada de Cristo y de los santos es el verdadero ideal de la justicia cristiana. Sin esta referencia se pierde el sentido del pecado y se disminuye la llamada permanente a la conversión y a la penitencia» ${ }^{268}$. «La ley del amor altruista (agape) es la norma según la cual se hace el juicio en todos los tiempos» ${ }^{269}$.

«Una denuncia clara y unívoca, que pondere convenientemente el bien de la Iglesia y de la humanidad, que se base en la dignidad del hombre como imagen de Dios y cuya única finalidad sea la paz y la reconciliación».

261. Mons. G. Prata, arzobispo de Cochabamba (Bolivia), 137.

262. Card. F. Macharski, arzobispo de Kraków (Polonia), 75.

263. Mons. F. Tomásek, arzobispo de Praga (Checoslovaquia), 172-3.

264. Card. J. L. Sin, arzobispo de Manila, 68.

265. Mons. S. Stefano Karlich, relator del Grupo B de lengua hispano-portuguesa, 208.

266. Mons. S. Stefano Karlich, relator del Grupo B de lengua hispano-portuguesa, 208.

267. Card. J. L. Sin, 68: «El pastor debe ser «profeta de la denuncia» y ministro de la reconciliación. No es ningún dilema. Es una doble función del sacerdote. Los conflictos y las divisiones están en expansión. La violación de los derechos humanos en muchos sitios alcanza el ápice de la injusticia. Hay que denunciar esta situación. Pero tal denuncia debe recordar a todos que las exigencias del Evangelio no admiten el odio, pero tampoco permiten que sea pisoteado el pobre»; S. Stefano Karlich, relator del Grupo B de lengua hispano-portuguesa, 208: «En cuanto pueblo profético, la Iglesia debe anunciar el Evangelio en su autenticidad, sin contaminaciones ideológicas. La denuncia, cuando es necesaria, debe madurarse con humildad y seriedad; no debe hacerse como una lucha programada de clase, sino con el propósito de convertir al Evangelio, el cual no excluye el derecho a una auténtica lucha por la justicia (cfr. Laborem exercens, n. 20)».

268. Mons. F. S. Aguilar, obispo de León, 121.

269. Mons. A. I. Fernández, arzobispo de Delhi (India), 166. 
«Cuando la Iglesia denuncia algo no debe dejarse atrapar por la sed de poder ni por los sistemas o lógicas de las que quiere liberar al hombre».

«A veces, en casos particulares, también el arma del silencio tiene valor de denuncia. Los profetas frecuentemente han testimoniado su denuncia con el martirio» ${ }^{270}$.

«Por lo que se refiere al ejercicio de la denuncia profética de la Iglesia señalamos los siguientes criterios:

-que la Iglesia mantenga su identidad

-que se mueva por su amor a la justicia, parte integrante de su misión evangelizadora

- que sea tempestiva y oportuna, formulada en documentos breves y claros

-que sea objetiva, sin dejarse envolver por las pasiones o los grupos

- que sea proporcionada al daño que se trata de evitar

-que sea fiel a la historia y al hombre concreto

-que sea fiel a Cristo y a su Evangelio, tomado en su totalidad

-que sea fiel a la Iglesia y a su misión que no solamente es evangelizadora sino también reconciliadora» ${ }^{271}$.

Denunciará las situaciones en las que se violan los derechos humanos «que en muchos lugares alcanza el ápice de la injusticia» ${ }^{272}$. El Evangelio nos pide «anunciar con audacia profética, con todos los medios posibles, la buena nueva en su aspecto escatológico de la vida eterna y en su fermento de promoción humana integral» ${ }^{273}$, «...la Iglesia pronuncia un juicio y una denuncia de los males que atormentan al hombre, ejerciendo un servicio profético:

-cuando revela la naturaleza del pecado incrustado en el corazón del hombre que, además, se infiltra en las culturas y en las estructuras sociales

—cuando, con espíritu de amor y humanidad, indica las raíces de las divisiones del hombre en sus diversos aspectos: políticos, económicos, culturales, religiosos etc.

- cuando alimenta la esperanza en la posibilidad de superar los conflictos, de llegar a un amplio acuerdo social y de instaurar una cultura del amor (necesidad de terminar con la proliferación de las armas, sobre todo, de las atómicas). Todo esto incluye también la esperanza de alcanzar una reconciliación ecuménica, sobre todo con las Iglesias orientales» ${ }^{274}$.

270. Mons. L. Monsengwo Pasinya, relator del Grupo B de lengua francesa, 206.

271. Mons. G. E. Santos Ascarza, relator del Grupo C de lengua hispano-portuguesa, 200.

272. Card. J. L. Sin, arzobispo de Manila, 68.

273. Mons. J. Delicado Baeza, arzobispo de Valladolid, 134.

274. Card. C. M. Martini, 220. 
El Evangelio «consuela y da esperanza, trata de hacer más humano el conflicto, al denunciar las violaciones de los derechos humanos por ambas partes; estimula las reformas de las estructuras, anima el diálogo y se esfuerza en vivir seriamente la celebración del Año Santo de la Redención» ${ }^{275}$.

De ninguna manera aceptará que las ideologías, por ejemplo de «seguridad nacional ${ }^{276}$, la marxista ${ }^{277}$, la teología de la liberación ${ }^{278}$, la capitalista ${ }^{279}$, ni los intereses geopolíticos de las grandes potencias asuman el papel de criterio orientador de la denuncia profética. Unas y otros, en lugar de solucionar, agravan los conflictos ${ }^{280}$, son fuentes de denuncias y sospechas contra la Iglesia ${ }^{281}$. Evitar la politización del pecado se ha convertido en un deber actual porque crea obstáculos a la reconciliación ${ }^{282}$.

«Uno de los pecados, causa de divisiones 'intolerables' en el seno de la Iglesia, lo es 'la gran miseria y falta de verdad'» (Pablo VI).

«El olvido o hasta el rechazo, sea de las verdades objetivas, sea de los valores fundamentales como también el olvido del deber de buscarlos sinceramente, abre las puertas a graves errores y equívocos. Cuando falta el amor a la verdad, se prepara la emboscada para todo tipo de engaños.

275. Mons. A. Rivera Damas, arzobispo de San Salvador (El Salvador), 116.

276. Mons. A. Rivera Damas, 116: «El conflicto se agrava con la presencia de ideologías: por un lado la de «la seguridad nacional» y, por el otro «la marxista». También existen en el país intereses geopolíticos de las grandes potencias, haciéndolo todo más complejo».

277. Mons. L. J. Cabral Duarte, arzobispo de Aracajú (Brasil): «...algunos teólogos difunden ideas inaceptables desde el punto de vista pastoral y teológico. Citaré dos ejemplos: ...la legitimidad y, hasta la necesidad, de la utilización del análisis y de las categorías marxistas en el trabajo social. de los católicos. Ideas que se están difundiendo mucho entre los católicos» (p. 217).

278. Mons. L. J. Cabral Duarte, arzobispo de Aracajú (Brasil, 112: «Quiero referirme a los problemas que la «teología de la liberación» suscita en toda la América Latina. Actualmente este nombre agrupa exclusivamente a las tendencias filo-comunistas, después de haber arrinconado a todas las demás tendencias.

«Esta «teología» impone, en muchos ambientes intelectuales y pastorales, las categorías del marxismo: La lucha de clases, la «praxis» como criterio último de verdad teológica... etc. Este modo de pensar domina en muchos seminarios y universidades católicas. No se contesta al Papa. Se le escucha, se calla y se continúa actuando como antes. Estamos en el tiempo de «la indiferencia respetuosa». El Sínodo debería pronunciarse sobre esta urgente reconciliación de muchas inteligencias católicas con el Supremo Magisterio de la Iglesia.

279. Mons. B. Mve'Engone, obispo de Owando (Gabón), 99.

280. Mons. A. Rivera Damas, 116; Mons. I. M. de Orbegozo y Goicoechea, obispo de Chiclayo (Perú), 165: «Si se buscan las causas, salta a la vista que ideologías sectarias tratan de descristianizar la sociedad, destruyendo sus estructuras fundamentales: La familia, la escuela, la información pública, etc. Se legaliza el divorcio, se despenaliza el aborto, se suprime la libertad de escuela:...».

281. Card. C. M. Martini, 192: «El conflicto social es ocasión frecuente de sospechas y denuncias contra la Iglesia, a veces sugeridas solamente por un esquematismo ideológico, aunque en otras ocasiones son una invitación a la Iglesia a un ejercicio más atento de su responsabilidad social.

282. Mons. N. J. López Rodríguez, arzobispo de Santo Domingo (Rep. Dominicana), 136. 
«La falta de verdad conduce a doctrinas teológicas marcadas por la alergia y por la oposición sistemática al magisterio, por la inclinación a preseńtar como tesis del magisterio hipótesis discutibles a la vez que a las tesis del magisterio se las convierte en hipótesis discutibles y por la tendencia hacia metodologías que desembocan en concepciones abiertamente marxistas.

«Conduce igualmente a relecturas del Evangelio, a opciones pastorales socio-políticas, al recurso a la violencia como opción preferencial por los pobres, a la participación directa en la guerrilla y el terrorismo, al robustecimiento, con todas las consecuencias, de la que, erróneamente es llamada «iglesia sopular».

«A todo esto añádase que, quienes luchan tenazmente por llevar todas es$s$ ideas a los centros de formación, no son solamente los laicos, sino tamén, y sobre todo, sacerdotes y religiosos» ${ }^{283}$.

\section{Formación de los confesores}

Es abrumadora la insistencia en la formación de los futuros confesores. Formación amplia, «en teología, en espiritualidad y en antropología, de modo que estén preparados para cooperar con el Espíritu Santo, hasta por medio de un diálogo oportuno, y profundo con el penitente» ${ }^{284}$; «una preparación psicológica tal que el futuro sacerdote esté convencido del deber que le incumbe de instruir, con perseverancia, a los fieles mediante una catequesis metódica sobre las verdades de la fe, sobre los principios morales y sobre el uso de los sacramentos. El sacramento de la reconciliación, que por su materia es ingrato y laborioso, requiere una catequesis especial».

«La formación litúrgica de los seminaristas debería poner un acento especial sobre los sacramentos del Bautismo y Reconciliación. Los estudiantes deberían recibir una información adecuada para que puedan ofrecer una buena catequesis a los catecúmenos y se les debería enseñar a preparar buenas y fructuosas celebraciones penitenciales».

283. Mons. A. Troyo Calderón, obispo auxiliar de S. José de Costa Rica, 121-122.

284. P. J. Pfab, Superior General de los Redentoristas, 87; Mons. A. Perraudin, arzobispo de Kabgayi (Rwanda), 68; Mons. S. Naidoo, relator del Grupo B de lengua inglesa, 196; Card. J. L. Bernardin, arzobispo de Chicago (USA), 71-72; Mons. S. Naidoo, obispo auxiliar de Cape Twn (Sudáfrica), 98-99; Mons. R. A. Surinach, obispo auxiliar de Ponce (Puerto Rico), 99; Mons. E. Wamala, obispo de Kiyinda-Mityana (Uganda), 101; Mons. D. Castrillon Hoyos, relator del Grupo A de lengua española, 198; Mons. L. Monsegwo Pasinya, relator del Grupo B de lengua francesa, 205; Mons. L. Averkamp, Grupn de lengua alemana, 209; Card. O. Rossi, 235. 236. 
Todo esto debería hacerse ya desde el seminario, puesto que el seminario ofrece «el ambiente ideal para formar tales ministros del sacramento de la reconciliación y penitencia» ${ }^{287}$. Por ello «los seminarios deberían dedicar mayor tiempo y talento a la preparación de los futuros sacerdotes para que puedan ser dignos ministros del sacramento de la reconciliación» ${ }^{288}$. «En los seminarios deberían cultivarse las virtudes humanas que son útiles para este ministerio. Deberían tener conocimientos críticos de los valores positivos de las ciencias humanas. Sus profesores, en seminarios y universidades, deben sobresalir por su ciencia y piedad» ${ }^{289}$. «...las mejores fuerzas deberían dedicarse a la sólida formación de los sacerdotes» ${ }^{290}$.

Se pide la «promoción de cursos de formación permanente» ${ }^{291}$, puesto que «en lo tocante a la preparación de los ministros de la penitencia, se ha observado que las nuevas orientaciones de teología moral han causado una cierta desorientación en los sacerdotes, particularmente en los más ancianos, y consiguientemente también en los fieles» ${ }^{292}$.

Finalmente se ha llegado a sugerir que el Sínodo pidiera al Papa que encomendara al dicasterio correspondiente la preparación de un documento de carácter normativo «que indicara todos los elementos que la Iglesia considera necesarios para la adecuada formación de buenos confesores y directores» ${ }^{293}$.

\section{Actitud del confesor}

«Se ha hecho notar la importancia de la actitud del confesor en la administración del sacramento de la reconciliación...» ${ }^{294}$. Y tiene la posibilidad de comportarse como respondiendo a dos grandes perspectivas: «el tribunal de la penitencia» o la misericordia amorosa de la parábola del hijo pródigo. Esta última parece más en consonancia con la Gaudium et Spes y con la mentalidad moderna» ${ }^{295}$.

«Juan Pablo II en la carta 'Dominicae coena', afirma que el sacerdote actúa 'in persona Christi'. Es necesario comprender todo el contenido de esta

287. Mons. W. Ch. Tumi, arzobispo coadjutor de Garoua (Camerún), 84.

288. Mos. T. Worlock, relator del Grupo de lengua inglesa, 197.

289. Mons. L. Monsegwo Psinya, relator del Grupo B de lengua francesa, 206.

290. Mons. J. de Jesús Pimiento Rodríguez, arzobispo de Manizales (Colombia), 94.

291. Mons. I. M. de Orbegozo y Goicoechea, obispo de Chiclayo (Perú), 173; Mons. T. Shibangu, relator del Grupo C de lengua francesa, 207.

292. Mons. G. E. Santos Ascarza, relator del Grupo C de lengua hispano-portuguesa, 199.

293. Mons. R. A. Surinach Carreras, obispo auxiliar de Ponce (Puerto Rico), 99.

294. Card. O. Rossi, 140.

295. Card. J. L. Sin, arzobispo de Manila, 170-1. 
expresión que dice más que 'en nombre' o 'en vez de'. 'In persona Christi' establece una identificación sacramental con Cristo Sumo Sacerdote».

«¿Qué significa todo esto en cuanto a la actitud del confesor?» ${ }^{296}$.

Pues significa que el sacerdote debe presentarse como «un padre, cuyo deber no consiste tanto en discernir con lucidez el pecado de su hijo, cuanto en comprender al pecador»; un padre que «acoge, escucha, lo instruye como padre, lo corrige, lo orienta, celebra el sacramento y lo estimula a seguir el camino. Con otras palabras: se trata de imitar a Cristo» ${ }^{297}$.

Siendo así iniciará la celebración del sacramento «con mentalidad de reconciliación» ${ }^{298}$, se mostrará rico en misericordia y perdón a imagen de Dios, fácilmente accesible y digno de que la gente deposite, sin dificultades, su confianza en él ${ }^{299}$, porque el penitente puede percatarse que el confesor es «comprensivo y concreto con él» ${ }^{300}$ y que está celebrando el sacramento «con amor y con verdadera atención» ${ }^{301}$. «Sobre todo los jóvenes piden que el sacerdote sea claro e iluminador, que se muestre amigo y que sea hombre de Dios y de paz», en una palabra que «a imagen de Cristo se sienta llamado a «redimir»y no a «condenar» ${ }^{302}$. Debería vivir la administración del sacramento como «un oficio de caridad ${ }^{303}$.

Se espera de él que, liberado del viejo espíritu de la perspectiva del tribunal de la penitencia, celebre el sacramento con «el nuevo espíritu», el propio de la misericordia amorosa de la parábola del hijo pródigo, que se caracteriza: «Por la búsqueda de un verdadero diálogo entre sacerdote y penitente con miras a su verdadera curación espiritual» ${ }^{304}$. Un diálogo paterno en el que «propone el sacramento de la reconciliación como un don de Dios al hombre, sin acrecentar la angustia del penitente insistiendo excesivamente en la confesión de los pecados según el número y la especie» ${ }^{305}$. Podríamos aplicarle al confe-

296. Mons. M. Pérez-Gil González, obispo de Mexicalo (Méjico), 116; Mons. L. L. Alvarado, obispo de Huacho (Perú), 146: «Es necesario anunciar al hombre de hoy, oprimido consciente o inconscientemente por el pecado, la Buena Noticia de Dios como Padre, como Amor y Misericordia, que es como Cristo nos lo ha revelado. El Sínodo, siguiendo la enseñanza del Santo Padre en su encíclica «Dives in misericordia» debería dar a esta solemne proclamación pontificia la más amplia y vigorosa resonancia».

297. Mons. G. E. Santos Ascarza, relator del Grupo C de lengua hispano-portuguesa, 200.

298. Mons. A. Mabutas y Llorén, arzobispo de Davao (Filipinas), 133.

299. Mons. W. Ch. Tumi, arzobispo coadjutor de Caroua (Camerún), 84.

300. Mons. P. F. Flores, arzobispo de San Antonio (USA), 115; Mons. Ph. Fanoko Kpodzro, obispo de Atakpamé, 162.

301. Mons. Ph. Fanoko Kpodzro, 162.

302. Card. O. Rossi, 140.

303. P. J. Pfab, Superior General de los Redentoristas, 87.

304. Mons. S. Naidoo, obispo auxiliar de Cape Twn (Sudáfrica), 98-99.

305. Mons. P. Verschuren, obispo de Helsinki, 80. 
sor lo que afirman de la Iglesia «que elija decididamente el camino del diálogo, del consenso, del corazón, más que el camino de la autoridad, que se despoje de todo atisbo de dominio ${ }^{306}$, que se muestre ministro de la misericordia y del amor de Dios, mantenga abiertas las puertas de la reconciliación y explore todos los caminos para posibilitar a los pecadores el retorno al Padre de la Misericordia ${ }^{307}$.

La oración y el estudio le ayudarán enormemente para «obtener la comprensión necesaria con un verdadero diálogo en la celebración del sacramento").

\section{PEnitenCIAS COMUNitARIAS SACRAMENTALES}

El Card. Martini enumera, en su relación del 30 de septiembre, el tema de la celebración comunitaria sacramental entre las cuestiones sobre las que más se han parado las Conferencias Episcopales y otros organismos eclesiásticos en sus conclusiones-respuesta dadas al estudio de los Lineamenta ${ }^{308}$.

A medida que se van estudiando las diversas, y a veces densas, intervenciones de los Padres tal como han llegado a nosotros, va aumentando la sorpresa al constatar que la mayoría de tales intervenciones se esfuerzan, con el máximo respeto y ponderación, por abrir caminos más amplios y posibilidades mayores a la celebración del tercer rito, o la celebración comunitaria pero con confesión individual.

Vaya por delante que esta fuerte corriente que defiende mayores posibilidades para la celebración de las penitencias comunitarias sacramentales no expresa la más mínima aninadversión por la forma privada de confesarse, sino que manifiesta gran aprecio por la misma y desea que se conserve en el patrimonio y praxis vital de la comunidad creyente, Pueblo de Dios ${ }^{309}$. Su preocu-

306. Card. A. Lorscheider, arzobispo de Fortaleza (Brasil), 81.

307. Mons. J. Babatunde Adelakun, obispo de Oyo (Nigeria), 83.

308. Card. C. M. Martini, 65: «La cuestión de la absolución general ha concentrado la atención de un elevado número de Padres, que se hän hecho intérpretes de las diversas situaciones locales y de las complejas preocupaciones connexas con su práctica». Como para contra balancear tal proclividad invita al Sínodo a que «la atención al tema de la absolución general no haga pasar desapercibidos los problemas planteados por las formas ordinarias» (ID., 193).

Card. F. Macharski, arzobispo de Krakòw (Polonia), 75; Mons. D. Castrillón, obispo de Pereira (Colombia), 105; Mons. M. F. Fernando, obispo de Chilaw (Sri Lanka), 110-111; Mons. O. Wüst, obispo de Basilea (Suiza), 119; Mons. S. Naidoo, relator del Grupo B de lengua inglesa, 197; Mons. T. Worlock, relator del Grupo C de lengua inglesa, 197; Mons. P. G. Cullinane, relator del Grupo A de lengua inglesa, 195; Card. A. Lorscheider, arzobispo de Fortaleza (Brasil), 183-184; Card. J. L. Bernardin etc., delegados de episcopado de Estado Unidos, 171-2; Mons. M. A. J. Gervais, obispo auxiliar de Londres (Canadá), 122.

309. Card. A. Lorscheider, arzobispo de Fortaleza (Brasil), 183; Mons. T. Tshibangu, relator del Grupo C de lengua francesa, 207. 
pación no es la de suprimir una forma de confesarse como la individual, no obstante reconozcan que el pueblo cristiano está dejando de practicarla, sino la de «recuperar la multiplicidad de formas atestiguada por la Sagrada Escritura y que fueron practicadas en los primeros siglos del cristianismo» ${ }^{310}$.

\section{Presupuestos en los que se apoya esta corriente}

1. Consideran que los problemas teológicos no impiden a la Iglesia establecer nuevas formas de celebrar el perdón de los pecados.

«La historia del sacramento de la penitencia nos enseña que la confesión auricular es una de las formas de este sacramento testimoniadas en la tradición de la Iglesia. La práctica de la confesión auricular ha ido acompañada de una menor frecuencia de la conversión interior. La confesión auricular manifiesta más claramente el aspecto personal del encuentro entre el penitente y el ministro del sacramento... pero deja en la penumbra el aspecto eclesial y comunitario del sacramento de la penitencia».

«Todos los pecados mortales, cometidos después del bautismo, deben ser confesados según el número, la especie y las circunstancias que cambian la especie y esto por derecho divino, como dice el concilio de Trento. No puede negarse esta necesidad. Pero, por otra parte, esta necesidad no impide que la Iglesia pueda adoptar otras formas de perdonar los pecados, como ocurre hoy con la fórmula de la penitencia comunitaria.

«Aunque se puedan cometer abusos, como sucede también con la confesión auricular, la fórmula comunitaria ofrece muchas ventajas para despertar el sentido de la penitencia. Parece oportuno que, sin omitir el valor de confesión auricular, no se impidan o minusvaloren las comunitarias» ${ }^{311}$.

Pensamiento que de alguna manera enriquece Mons. Gilbert Aubry, obispo de La Réunion: «El problema de incluir las celebraciones comunitarias, con confesión y absolución colectivas, en la práctica ordinaria del sacramento de la penitencia, evidentemente que no deriva ni de su incompatibilidad con la forma del sacramento ni de su incompatibilidad con la estructura de la economía divina» ${ }^{312}$.

$\mathrm{Y}$ el grupo $\mathrm{C}$ de lengua francesa concluía sus discusiones diciendo: «aun siendo conscientes de los problemas teológicos inherentes a esta práctica, la de la celebración comunitaria con confesión y absolución generales, ha subraya-

310. P. G. Ferrari, Superior General de los Misionerso Javerianos, 88; Mons. O. Wüst, obispo de Basilea (Suiza), 119.

311. Card. A. Lorscheider, 183.

312. Mons, G. Aubry, obispo de La Réunion, 157. 
do los beneficios y ventajas prácticas que ofrece y ha expresado el deseo de verla conservada en el sistema penitencial de la Iglesia», porque considera que el aceptarla y extenderla "es un problema de conveniencia y oportunidad», «postergando la confesión individual de los pecados a un tiempo posterior» ${ }^{313}$.

El mismo cardenal Martini hace notar, en su relación del 30 de septiembre que «entre las cuestiones de que se ocupa el Instrumentum Laboris... algunas son de orden ético y teológico, mientras que otras son prevalentemente de orden pastoral». Y por si fuera poco precisa: «Entre las cuestiones de índole ética y teológica enumeramos las siguientes: la relación entre el pecado individual y los males que afligen al mundo; la dimensión personal y social del pecado y la recta concepción de la libertad del hombre» ${ }^{314}$. «Por lo que se refiere a las cuestiones de índole prevalentemente pastoral nos referimos a las relaciones entre el sacramento de la penitencia y el de la eucaristía; a la confesión individual y a la celebración sacramental comunitaria; a la absolución general; a la celebración de la penitencia por los pecados veniales y, finalmente, a la formación de los confesores» ${ }^{315}$.

No obstante, el catalogar este problema como «de conveniencia y oportunidad pastoral» no autoriza a tratarlo a la ligera. El grupo B de lengua francesa concluía que el problema de la confesión individual y el de la absolución general debía tratarse «teniendo en cuenta las exigencias de las iglesias particulares, estudiadas en el seno de las conferencias episcopales y salvaguardando la integridad de la fe, el bien de las almas y el espíritu de colegialidad con el $\mathrm{Pa}$ pa» ${ }^{316}$.

\section{Los ritos no son más que medios}

«No se da la alianza entre Dios y el hombre sino a través de mediaciones concretas: Mediación de palabras y ritos, mediación de personas encargadas de transmitir estas palabras y de hacer vivir estos ritos» ${ }^{317}$.

Es acertado recordar aquí la neta distinción que establece el Nuevo Ritual de la Penitencia entre el sacramento y las formas de celebrarlo ${ }^{318}$.

313. Mons. T. Tshibangu, relator del Grupo C de lengua francesa, 207.

314. Card. C. M. Martini, 64.

315. Card. C. M. Martini, 65.

316. Mons. L. Monsegwo Pasinya, relator del Grupo B de lengua francesa, 206.

317. Mons. F. Favreau, obispo de Nanterre (Francia), 179-180.

318. Ritual de la penitencia, Madrid 1975. 
3. No siendo los ritos más que medios, cada una de las diversas formas de celebrar la reconciliación posee sus propios valores

«Cada uno de los tres ritos tiene su propio valor distinto. Animemos a los fieles a usar los tres ritos en su búsqueda de la reconciliación y de la penitencia» ${ }^{319}$.

Los obispos holandeses describen con entusiasmo las «ventajas y beneficios» de las celebraciones comunitarias sacramentales, constatados en la práctica ${ }^{320}$. Y no están solos los holandeses en la defensa de esta tesis. Como grupo también los obispos suizos se declaran decididos defensores de las celebraciones comunitarias sacramentales: «Frente a la crisis de la confesión individual, visto que cada vez se frecuenta menos y la carencia de sacerdotes es notoria, la Conferencia Episcopal ha decidido, apoyándose en el Ordo Poenitentiae, que se puedan celebrar penitencias comunitarias con absolución general. Para muchos fieles ello ha significado abrirles el camino de la conversión y del perdón transmitido por la Iglesia. Los fieles, además, experimentan la dimensión eclesial de la culpa y de la reconciliación» ${ }^{321}$.

«La Conferencia Episcopal Australiana ha acogido con entusiasmo las nuevas oportunidades de celebrar el sacramento, con el respeto de las condiciones debidas, ofrecidas por el tercer rito. Los obispos han tomado atentamente en consideración el conjunto de estas condiciones y han insistido en su observancia en nuestras diócesis».

«La experiencia del uso del tercer rito ha sorprendido a los pastores más celosos y expertos. La cualidad de las celebraciones ha sido notable. Muchos fieles hablan de una nueva experiencia de conversión y de una nueva conciencia de la Iglesia como comunidad reconciliante. No ha llevado a la desaparición de la confesión individual, más aún muchos sacerdotes afirman que ha ayudado mucho a la frecuencia del primer rito» ${ }^{322}$.

Entre los «beneficios y ventajas» subrayan el promover la formación de la conciencia ${ }^{323}$, el anunciar y poner en evidencia el primado del amor incondicional de Dios ${ }^{324}$, lo que les abre «el camino de la conversión» ${ }^{325}$, la «experiencia de los aspectos comunitarios del pecado y del perdón transmitido por

319. Mons. S. E. Carter, arzobispo de Kingston (Jamaica), 67.

320. Mons. J. B. Möller, obispo de Groningen (Holanda), 111.

321. Mons. O. Wüst, obispo de Basilea (Suiza), 119.

322. Mons. B. J. Wallace, obispo de Rockhamptor (Australia), 156; Mons. T. Tshibangu, relator del Grupo $C$ de lengua francesa, 207.

323. Mons. J. B. Möller, obispo de Groningen (Holanda), 111.

324. Mons. B. Blanchet, obispo de Gaspé (Canadá), 130-131.

325. Mons. O. Wüst, obispo de Basilea (Suiza), 119. 
la Iglesia» ${ }^{326}$. Y van más allá sus efectos benéficos: Con la celebración de las penitencias comunitarias muchos fieles, alejados de la confesión individual, retornan a ella con mayor calidad en su celebración ${ }^{327}$. Se estima que contribuye a vivir el sacramento con la alegría que debe producir el encuentro con Dios y con los hermanos, liberando al sacramento de la «connotación de tristeza y de punición que se le ha atribuido» ${ }^{328}$.

A la luz de estas ventajas es lógico que algunos padres sinodales concluyan que «sería de gran ayuda pastoral una consideración «más positiva» de los valores de la absolución general, al igual que de sus límites y de las condiciones necesarias» ${ }^{329}$, que «es necesario liberar a fondo de repercusiones afectivas el problema relativo al mejoramiento constante de las cualidades de las celebraciones comunitarias y así los fieles que las frecuenten redescubrirán el sentido del pecado, del perdón, de la culpa, de la penitencia y de la conversión» ${ }^{330}$.

Concluyo con monseñor Bertrand Blauchet, obispo de Gaspé (Canadá): «Estas consideraciones teológicas, entre otras; parecen lo suficientemente importantes como para justificar una mayor profundización problema» ${ }^{331}$.

326. Mons. O. Wüst, 119; Mons. R. Nze Abuy, arzobispo de Malabo (Guinea Ecuatorial), 186: «La celebración comunitaria de la reconciliación ha revalorizado y actualizado un aspecto muy descuidado en los últimos siglos. Me refiero al aspecto comunitario o social de la penitencia. Se encuentra en relación con el pecado, que siempre es social, puesto que disminuye el testimonio vital de la comunidad, ataca la vida comunitaria y rompe el amor. Algunos exegetas sostienen que cuando el Apóstol dice: «quien recibe o come indignamente el pan o bebe el caliz del Señor, se hace culpable del Cuerpo y la Sangre del Señor» (1Cor 11,27), que no se refiere solamente al cuerpo eucarístico, sino también al cuerpo de la Iglesia, contra el cual se peca. Por esta razón se pedía, en la práctica de la Iglesia antigua, la conversión y reconciliación con la Iglesia visible.

«En la celebración comunitaria los cristianos se encuentran como hombre en comunión e integración recíprocas. Quienes participan en ella se sienten culpables el uno frente al otro y todos frente al mundo, la Iglesia y Dios: juntamente buscan una nueva orientación en cuanto comunidad cristiana. Y todo esto se hace en un clima de oración».

327. Mons. B. J. Wallace, obispo de Rockhamptor, 156; Mons. M. Maître, obispo de Bambari (Rep. Centroafricana), 188: «Las bellas celebraciones comunitarias con absolución colectiva pondrán remedio a la pérdida del sentido del pecado y a la disminución de la frecuencia del sacramento. La lectura de la Palabra de Dios, la homilía, el examen de conciencia, a veces la confesión de algunas culpas devolverán el sentido de la culpa personal y de la misericordia divina, con un auténtico deseo de conversión.

«Los fieles, así preparados, después sentirán la necesidad de un encuentro personal con el sacerdote, que tendrá lugar con una actitud distinta de aquella con que se iba a las confesiones en serie con ocasión de las grandes fiestas».

328. Mons. T. Tshibangu, relator del Grupo C de lengua francesa, 207.

329. Mons. R. Vidal, obispo de Cebú (Filipinas), 155.

330. Mons. M. Maître, obispo de Bombari (Rep. Centroafricana, 188.

331. Mons. B. Blanchet, obispo de Gaspé (Canadá), 131; Mons. S. E. Carter, arzobispo de Kingston (Jamaica), 67: Ni podemos olvidar que «los sacramentos no son solamente un canal de la gracia, sino también un acto público de culto. Y desde este punto de vista el tercer rito es el más perfecto de los tres». 
4. No proponen la tesis de la ampliación de las penitencias comunitarias como una «total sustitución de la confesión individual» ${ }^{332}$

Están convencidos que las celebraciones comunitarias solamente pueden perjudicar a la confesión individual cuando se practican «de manera indiscriminada y habitual» ${ }^{333}$. Y lo que afirma el grupo $\mathrm{C}$ de lengua inglesa, lo confirman los obispos suizos y australianos con los resultados obtenidos en la práctica. El episcopado suizo atestigua que ha «progresado la calidad de la confesión individual así como ha abierto a muchos fieles el camino hacia la conversión y el perdón transmitido por la Iglesia» ${ }^{334}$. Poco antes había recogido la «sorpresa de los pastores más celosos y expertos» australianos, porque el «entusiasmo» con que la iglesia australiana había puesto en práctica las posibilidades abiertas al tercer rito por el Ordo Poenitentiae no sólo «no había conducido a la desaparición de la penitencia individual», sino que «muchos pastores constataban el retorno de muchos a la celebración frecuente del primer rito» ${ }^{335}$.

La realidad se pone así de parte de quienes proponen «ambas formas de celebración de este sacramento, individual y general», con el objetivo «de educar sistemáticamente a nuestra gente en el valor de la confesión individual, elegida libremente, y darles numerosas oportunidades para la celebración de este tipo de confesión» ${ }^{336}$.

Riesgo de abusos y abusos reales se dan o pueden darse. Efectivamente insisten en ello varios padres sinodales. El cardenal Sabattani recuerda al Sínodo que «tiene la misión de eliminar todos los abusos constatados en el impartir indiscriminadamente la absolución general...» ${ }^{337}$. Según el cardenal

332. Mons. S. E. Carter, 67.

333. Mons. T. Worlock, relator del Grupo C de lengua inglesa, 197.

334. Mons. $O$. Wüst, obispo de Basilea (Suiza), 119: «...la Conferencia episcopal ha determinado, basándose en el Ordo Poenitentiae, que se puedan celebrar penitencias comunitarias con absolución general. A muchos fieles se les ha abierto el camino de la conversión y del perdón transmitido por la Iglesia. Los fieles experimentan la dimensión eclesial de la culpa y de la reconciliación».

335. Mons. B. J. Wallace, obispo de Rockhamptor (Autralia), 156.

336. Mons. M. F. Fernando, obispo de Chilaw (Sr Lanka), 110-111: «La disminución de los católicos que se acercan a la confesión «no puede ser atribuido al abuso de la tercera forma de reconciliación...».

337. Card. A. Sebattani, relator del Grupo de lengua latina, 202; Mons. J. de Jesús Pimiento Rodríguez, obispo de Manizales (Colombia), 93-4: «Es doloroso constatar que la deseada renovación de la celebración del sacramento ha fracasado. De hecho, su frecuencia ha disminuido vistosamente, se recibe de forma rutinaria, se abusa de la absolución colectiva y los progresos hacia la nueva disciplina son aún insuficientes»; Mons. R. A. Surinach Carreras, obispo auxiliar de Ponce, 99: «...las absoluciones generales, particularmente cuando son impartidas abusivamente 
Godfridus Danneels «el juicio pastoral sobre el valor de las celebraciones comunitarias no es unívoco: podría conducir a la inanición de la confesión auricular. Además debe hacernos reflexionar el deterioramento irreversible de la disciplina penitencial sufrido por las Iglesias de la reforma» ${ }^{338}$. Pensamiento éste que explicita monseñor Paul J. Cordes, vicepresidente del Pontificio Consejo para los Laicos: «La disponibilidad de los fieles a acusar concretamente sus propios pecados en una confesión individual ha disminuido fuertemente en los últimos tiempos. ¿Deberá la Iglesia utilizar más ampliamente la absolución general por esta razón?

«La orientación de la respuesta nos la da la mirada sobre el desarrollo habido en tres confesiones no católicas. Martín Lutero, Juan Calvino y el primer Sínodo de los «Viejos Católicos» (1874), después de la separación de Roma, no tomaron posición alguna contra la confesión auricular, sino que la consideraron válida y hasta le imprimieron rigor en los casos de pecados graves. $\mathrm{Pe}$ ro habitualmente era suficiente el reconocimiento comunitario de la propia situación de pecadores. El resultado de esta nueva perspectiva es que en las tres confesiones, a lo largo de los siglos, la confesión auricular ha perdido todo significado pastoral. Esta sola constatación hace comprender que la Iglesia Católica debe ser muy prudente a la hora de aceptar la absolución general, si quiere mantener la confesión individual» ${ }^{339}$.

Quienes propugnan un abanico más amplio de posibilidades para las penitencias comunitarias no niegan que se hayan dado o puedan darse abusos. Tampoco los justifican. Sencillamente los valoran de manera diversa. Consideran que solamente un uso desconsiderado de la celebración comunitaria podría perjudicar al sacramento ${ }^{340}$, abuso de cuya existencia, que no dan por supuesta, se permiten dudar, como lo indica el interrogante presentado por cuatro delegados del episcopado americano: «¿Hay evidencia de que se esté produciendo un uso indiscriminado de la absolución general?» ${ }^{341}$. Además no solamente perjudica al sacramento el abuso que se produzca en las celebraciones comunitarias, sino también el que se produzca en cualquiera de los ritos de celebración y los abusos se dan o pueden darse en todos y en cada una de las formas de celebración ${ }^{342}$. Muy lógicamente concluye, pues, el grupo A de lengua

con desprecio de las condiciones necesarias, no pueden contribuir al bien sobrenatural de los fieles y tampoco de los sacerdotes u obispos que las administran»; Mons. E. de Araújo Sales, arzobispo de Río de Janeiro, 177: «La absolución colectiva, cuando se celebra en contraste con las directivas que regulan la materia, y el alejamiento del sacramento han producido daños a la Iglesia».

338. Card. G. Danneels, 205.

339. Mons. P. J. Cordes, 158.

340. Card. E. de Araújo Sales, arzobispo de Río de Janeiro, 176-177.

341. Card. J. L. Bernardin y otro de Estados Unidos, 171-172.

342. Card. A. Lorscheider, obispo de Fortaleza (Brasil), 183. 
española: «El riesgo genérico de no valorar debidamente la confesión personal, no debería ser obstáculo para la reconciliación mediante la absolución colectiva, si se dan las condiciones requeridas...» ${ }^{343}$.

\section{Aceptan, con sentido eclesial, las condiciones requeridas para el recto uso de las celebraciones comunitarias sacramentales ${ }^{344}$}

Tal aceptación, en cambio, no les impide interpretar divergentemente la existencia o no de tales condiciones. Se palpa muy claramente la doble mentalidad interpretativa. La corriente proclive a restringir al máximo los casos de celebraciones comunitarias sacramentales se centra en un examen minucioso de tales condiciones desde un punto de vista, diríamos legalista ${ }^{345}$. En cambio los propensos a defender su ampliación se guían más bien por una interpretación teleológica. Parecen partir de la convicción de que tales condiciones son propuestas con la intención de evitar los abusos o «uso indiscriminado» de las celebraciones comunitarias sacramentales, para que no incidan negativamente en la celebración individual. Consiguientemente su horizonte es mucho más amplio. Se mueven con la ilusión de acercar a las personas al sacramento y para ello, mientras son exigentes consigo mismos estando dispuestos a la celebración individual, también están abiertos a las celebraciones comunitarias siempre que el bien de las personas así lo requiera» ${ }^{346}$.

Se comprende que, desde estos presupuestos, los defensores de la amplia-

343. Mons. D. Castrillón Hoyos, relator del Grupo A de lengua española, 198.

344. P. G. Ferrari, Superior General de los Misioneros Javerianos, 88.

345. Card. G. Danneels, 204-205.

346. Mons. L. Monsegwo Pasynia, obispo auxiliar de Kisangani (Zaire), 108-109: «Siguiendo las directivas conciliares, tanto el rito como las formas de la penitencia deben encarnar lo mejor posible las diferentes dimensiones del sacramento, su naturaleza y sus efectos.

«Un primer paso se dio en 1974 con la creación del Ordo Poenitentiae, que recordaba la acción de las personas divinas en el sacramento de la penitencia, la mediación de la Iglesia y el aspecto comunitario de esta celebración. Pero tanto el Ordo Poenitentiae como el Concilio invitaban a la Conferencia Episcopal a proponer fijar y poner en práctica aquellos elementos particulares susceptibles de convertir la práctica sacramental en algo más activo y fructífero.

«Por ello la CEZ se permite subrayar los siguientes elementos que propone a la atención del Sínodo:

1.- "Que se favorezca la diversificación de la fórmula de absolución, de manera que pueda expresarse, de cuando en cuando, la intercesión y la invocación del sacerdote en favor del penitente, la solidaridad del uno y del otro en el arrepentimiento y en la reparación, la gravedad del pecado y de la transgresión cometida, etc.

2.- «Dado el insuficiente número de sacerdotes en este país de misión, es necesario que, la disciplina en vigor sobre la celebración comunitaria de la penitencia, sea revisada para poder asegurar a todos los penitentes - también sin acusación individual, si es necesario- la seriedad de la conversión y de la reparación». 
ción de posibilidades de celebraciones comunitarias sacranıentaies consideren que las condiciones requeridas «se verifican muy frecuentemente; en los «bellos días pasados» de la confesión frecuente; tales condiciones se verificaban, en muchas parroquias, todas las semanas, puesto que, dado el gran número de penitentes, las confesiones eran escuchadas, casi inevitablemente, de manera superficial. Éste era el caso, en particular, de las confesiones de los niños» ${ }^{347}$. «Parece que 'los impedimentos físicos y morales' se han convertido en la situación permanente en algunas tierras de misión y en muchas parroquias en las que existe una fuerte desproporción entre el número de fieles y el de sacerdotes. ¿Cómo puede un solo sacerdote proveer a las necesidades sacramentales de una parroquia de 20 ó 30, y a veces de 50 ó 100 mil habitantes? Por ello sería de gran ayuda una perspectiva pastoral que considerara de manera más positiva los valores, y también los límites y las condiciones necesarias para las celebraciones comunitarias sacramentales» ${ }^{348}$

6. La aceptación respetuosa de las condiciones prescritas no les impide someterlas a un detenido análisis crítico

Los interrogantes que los mismos obispos se han hecho y han planteado en voz alta en el aula sinodal son altamente ilustrativos y hasta tranquilizadores para cuantos deben exponer y reflexionar sobre temas morales.

El cardenal Ratzinger, prefecto de la S. Congregación de la Doctrina de la Fe, recordaba cuidadosamente a los sinodales las Normas Pastorales del 16 de junio de 1972 relativas al sacramento de la reconciliación al igual que las prescripciones del nuevo Código de Derecho Canónico que, en realidad, son restrictivas con relación al nuevo Ordo Poenitentiae ${ }^{349}$. Al cardenal Ratzinger se une, como era de esperar, el card. Casoria, prefecto de la S. Congregación para los Sacramentos y el Culto Divino. Les siguen algunos grupos y también numerosos obispos. Así el grupo de lengua latina, cuyo relator era el cardenal Sabattani, recuerda que «la misión del Sínodo es la de eliminar los abusos aparecidos con el uso indiscriminado de la absolución general y promover la observancia de las Normas Pastorales, emanadas por la S. Congregación para

347. Mons. S. E. Carter, arzobispo de Kingston (Jamaica), 67; Mons. M. F. Fernando, obispo de Chilaw (Sri Lanka), 110: «Por una parte se debe conservar la confesión individual auricular. Pero, por otra, el Sínodo debería dar los pasos concretos para hacer accesible el sacramento de la reconciliación a la gente de nuestro tiempo, que tiene exigencias particulares y frecuentemente se le ponen obstáculos indebidamente por la falta de sacerdotes»; Mons. L. Monsegwo, obispo auxiliar de Kisangani (Zaire), 108-109; Mons. S. E. Carter, obispo de Kingston (Jamaica), 67.

348. Mons. R. Vidal, arzobispo de Cebú (Filipinas), 166.

349. Card. J. Ratzinger, 138-9. 
la Doctrina de la Fe en 1972 y recibidas sintéticanente por el nuevo Código de Derecho Canónico que priva en toda decisión a los sacerdotes y reserva a las Conferencias Episcopales nacionales el establecer los criterios según los cuales se determinará la existencia de la causa grave, que justificaría la celebración del sacramento con tal forma extraordinaria» ${ }^{350}$.

De entre los obispos, monseñor Myroslaw Ivan Lubachivsky decía: «Según la Comisión teológica internacional la confesión general de los pecados no basta en las situaciones normales. De hecho los pecados graves deben ser confesados... La confesión general prorundiza y despierta el espíritu de penitencia. Pero la confesión y absolución generales solamente pueden usarse en situaciones de emergencia extraordinaria.

«El Nuevo Código dice lo mismo y precisa las condiciones necesarias para poder celebrar comunitariamente la reconciliación...» ${ }^{351}$.

No obstante todos estos recuerdos traídos a la memoria y convenientemente subrayados por personas tan autorizadas como el cardenal Ratzinger, prefecto de la Sagrada Congregación para la doctrina de la Fe, la gran confianza y libertad reinantes en el Sínodo permitió a otros muchos Padres exponer sus dudas en forma afirmativa o, al menos, interrogativa. Creo que la simple transcriptición de sus preguntas, deseos y afirmaciones será instructiva:

a. En cuanto a la confesión individual, obligatoria después de una celebración comunitaria sacramental

«Se siente la necesidad de una investigación teológica que aclare ciertos aspectos de la doctrina del Concilio de Trento sobre los requisitos por ley divina para la remisión de los pecados» ${ }^{352}$.

«Es necesario aclarar si 'la expresión: confesión de los pecados iure divino debe interpretarse según la concepción actual o si es simplemente una obligación disciplinar» ${ }^{353}$.

«Teniendo presente la situación actual, existente en algunos sectores y en

350. Ciard. G. Casoria, 149-150; Card. A. Sabattani, relator del Grupo de lengua latina, 202; Card. G. Danneels, 205; Mons. R. A. Surinach Carreras, obispo auxiliar de Ponce, 99, en nombre de la Conferencia Episcopal de su país; Card. E. Araújo Sales, arzobispo de Río de Janeiro, 176; Mons. J. Babatunde Adelakun, obispo de Oyo (Nigeria), 82-83, en nombre de la Conferencia episcopal de Nigeria; Card. J. Landázuri Ricketts, arzobispo de Lima, 74-75; Mons. F. Franic, arzobispo de Split-Makarska (Jugoslavia), 90-91; Card. J. Höffner, arzobispo de Colonia, 211; Card. J. Glemp, arzobispo de Gniezno e Warsawa (Polonia), 153; Mons. A. Tatianna Sanon, obispo de Bobo-Dioulasso (Alto Volta), 164; Mons. F. M. da Costa, arzobispo de Huambo (Angola), 144.

351. Mons. M. I. Lubachivsky, 190.

352. Mons. T. Worlock, relator del Grupo C de lengua inglesa, 197.

353. Mons. J. Wanke, administrador apostólico de Erfurt-Meiningen (Berlín), 89. 
algunos países, sería necesario explicar más claramente la razón que ha llevado a la Iglesia a establecer la necesidad de la confesión individual» ${ }^{354}$.

El grupo B de lengua inglesa señala que un problema que espera ser aclarado es: «¿El privilegiar a la absolución individual se basa sobre motivos netamente pastorales o compromete también temas doctrinales?» ${ }^{355}$.

«¿Cómo se puede demostrar, interrogan los cuatro delegados del episcopado norteamericano, que la obligación de confesar los pecados mortales después de su perdón mediante una absolución general se basa en las exigencias y derechos de la naturaleza humana y en la estructura del sacramento?» ${ }^{356}$.

Ya hemos leído la respuesta que da el cardenal Ratzinger: «¿La confesión personal es elemento esencial del sacramento? La respuesta es sí, como resulta claramente de la definición del Concilio de Trento y como se trasluce también del examen de la estructura antropológica y sacramental de la «conversiónpenitencia».

«De hecho la recepción personal es un elemento esencial de todo sacramento que es dado a esta persona determinada y no al grupo. Además la absolución tiene un carácter de juicio y terapéutico. Se le otorga como respuesta a culpas precisas cometidas personalmente. El pecado hiere no solamente a la persona, sino también a la sociedad: sólo la confesión personal es acción verdaderamente social» ${ }^{357}$.

Por otra parte nos encontramos con manifestaciones como las que siguen:

«Si reflexionamos sobre la judicialidad de la absolución sacramental tal como ha sido definida por Trento, tratando de penetrar en su sentido, concluimos que no puede interpretarse refiriéndola a las formas del acto judicial humano; que no puede reducirse, por parte del sacerdote, a un simple reconocimiento de los hechos y al juicio sobre ellos y, por parte del penitente, tampoco puede reducirse a un simple acto infortamivo, preliminar al sucesivo juicio.

«La confesión «numérica y específica» no es la simple declaración de los pecados, sino la toma de actitud frente a ellos: es la acogida del juicio de Dios sobre uno mismo, proclamado por la Iglesia, un juicio que no busca la muerte sino la salvación del pecador. Va unida, por tanto, a la «confessio laudis»e implica el reconocimiento de la señoría de Dios...» ${ }^{358}$.

También el Card. Luis Lorscheider, arzobispo de Fortaleza (Brasil) ha creído poder afirmar: «Todos los pecados mortales, cometidos después del

354. Mons. R. Vidal, arzobispo de Cebú (Filipinas), 166.

355. Mons. T. Worlock, relator del Grupo C de lengua inglesa, 196.

356. Card. J. L. Bernardin y otros delegados del episcopado norteamericano, 172.

357. Card. J. Ratzinger, 139.

358. Card. M. Cé, patriarca de Venecia, 129-130. 
bautismo, deben ser confesados según su especie, número y las circunstancias que cambian la especie como dice el Concilio de Trento. No se puede negar esta necesidad. Pero, por otra parte, esta necesidad no impide que la Iglesia pueda aceptar otras formas de perdonar los pecados. Esto es lo que ocurre hoy con la fórmula de la penitencia comunitaria.

«Aunque puedan darse abusos como también puede ocurrir con la confesión auricular, esta fórmula ofrece muchas ventajas para despertar el sentido de la penitencia. Por lo demás parece oportuno que, sin descuidar el poner de relieve el valor de la confesión auricular, no se impidan o minusvaloren las comunitarias» ${ }^{359}$.

Ni podemos olvidar que Juan XXIII en 1962 «ha permitido al Sudán el uso del rito de la confesión general con absolución general sin la obligación de confesar los pecados mortales en una sucesiva confesión individual». Así hasta 1972 en que les retiraron dicha concesión y les impusieron atenerse a la ley general de la Iglesia ${ }^{360}$.

También recuerdan los defensores de la corriente más abierta la realidad que encuentran en sus iglesias:

a. En algunas comunidades no se comprende «la obligación de tener intención de confesar las propias culpas graves «apenas posible» y personalmente. Tal obligación «hace que esta absolución general sea muy difícil de comprender por parte de los cristianos que la reciben» ${ }^{361}$.

Abundan en el mismo pensamiento los obispos de Ghana que «piden una precisión sobre la validez de la absolución general, especialmente en lo relativo a la obligación de confesar «los pecados graves» después de una absolución y a propósito del penitente de «confesar en el tiempo debido todos los pecados graves que no pudo confesar». En los penitentes surge la duda sobre si han sido absueltos o no ${ }^{362}$.

b. En algunas, o en varias, de esas comunidades resulta casi imposible la práctica de la confesión posterior: «En los casos en los que se ha recibido varias veces consecutivas la absolución general, la confesión individual de «los pecados graves» es casi imposible, dada la falta de sacerdotes, especialmente cuando un solo sacerdote debe visitar varios poblados» ${ }^{363}$.

«Dado, sobre todo, el insuficiente número de sacerdotes en los países de misión es necesario que la disciplina sobre la celebración comunitaria, ac-

359. Card. A. Lorscheider, arzobispo de Fortaleza (Brasil), 183-184.

360. Mons. G. Zubeir Wako, arzobispo de Khartoun (Sudán), 135.

361. Mons. R. Gay, Superior General de los Misioneros de África, 124.

362. Mons. F. Kofi Anani Lodonu, obispo de Keta-Ho (Gana), 141.

363. Mons. Francis Kofi Anani Lodonu, 141. 
tualmente en vigor, sea revisada de modo que se asegure a los penitentes la seriedad de la conversión y de la reparación, aun sin la acusación individual si ello fuere necesario» ${ }^{364}$.

\section{b. También plantean interrogantes sobre ciertas adjetivaciones que se añaden a la confesión individual.}

¿Qué alcance tiene la afirmación de que la confesión individual es la «única vía ordinaria»?

«La expresión «única vía ordinaria» (Nuevo Código de Derecho Canónico 960) referida a la confesión individual sólo parece tener validez cuando se da abundancia de ministros y de tiempo. Pero el término «única» que califica a «ordinaria» necesita alguna explicación. Parece que los «impedimentos físicos y morales» se han convertido en situación permanente en algunas tierras de misión y en algunas parroquias en las que se da una fuerte desproporción entre el número de fieles y el de sacerdotes. ¿Cómo puede un solo sacerdote responder a las necesidades sacramentales en parroquias de 20 ó 30, y a veces, hasta de 50 mil almas?» ${ }^{365}$.

Los países de misión se han mostrado particularmente sensibles a este punto. Así Mons. Roberto Gay, superior de los Misioneros de África constata que «los beneficios de la confesión individual están fuera del alcance de muchas comunidades cristianas, por el simple hecho de que no hay sacerdotes suficientes para asegurar este ministerio, como ocurre en muchas iglesias de África y de Filipinas» ${ }^{366}$.

También Mons. Manuel Carter escribe: «El Instrumentum Laboris» deplora el uso del tercer rito cuando no se dan las condiciones previstas. ¿No tendríamos que lamentar su no utilización cuando se verifican dichas condiciones? Los fieles necesitan instrucciones para evitar abusos... Muy frecuentemente se verifican las condiciones que justifican el uso de las celebraciones comunitarias...» ${ }^{367}$.

Finalmente la Iglesia del Sudán es testigo de los «notables problemas pastorales» que ha causado en esas comunidades la supresión, en .1972, de la facultad otorgada por Juan XXIII de celebrar «la confesión general con absolución general sin la obligación de confesar los pecados mortales en una confesión posterior individual» ${ }^{368}$.

364. Mons. L. Monsegwo Pasynia, obispo auxiliar de Jisangani (Zaire), 109.

365. Mons. R. Vidal, arzobispo de Cebú (Filipinas), 166.

366. Mons. R. Gay, Superior General de los Misioneros de África, 123.

367. Mons. S. E. Carter, arzobispo de Kingston (Jamaica), 67.

368. Mons. G. Zubeir Wako, arzobispo de Khartoum (Sudán), 135. 
c. Finalmente, los cuatro delegados del episcopado norteamericano proponen al Sínodo la siguiente pregunta: ¿Cuál es el significado del «per lungo tempo» como condición para recurrir a la absolución general?» ${ }^{369}$.

\section{Principios}

1. La misión de hacer llegar a todos «la oportunidad de reconciliarse con Dios»

La misión reconciliadora de la Iglesia ha logrado un alto grado de expresividad, y en repetidas ocasiones, en este Sínodo. Aquí recogeré solamente aquellas expresiones que ponen en relación directa la misión reconciliadora de la Iglesia con las formas de reconciliar.

«La experiencia cotidiana muestra la urgencia de que se encuentren nuevas formas pastorales para la reconciliación y también la urgencia de que, cuando se dan las condiciones previstas se utilice la forma de la absolución general prevista por el Ordo Poenitentiae, para ofrecer a todos la oportunidad de reconciliarse con Dios. En caso contrario la crisis y desafección hacia el sacramento de la reconciliación se agravará» ${ }^{370}$.

Si la Iglesia quiere seguir siendo signo y sacramento de reconciliación es deseable que los Padres sinodales reconsideren, por una parte, las necesidades pastorales de las comunidades cristianas numerosas y carentes de ministros de la reconciliación y conceda, por la otra, a las celebraciones comunitarias sacramentales todo el valor sacramental y eclesial que encierran en sí. En estas iglesias «cuando el sacerdote puede participar y presidir tales celebraciones, puede dar a estos cristianos la absolución general según el ritual de 1973» ${ }^{371}$.

La finalidad, conscientemente perseguida, es la de orientar hacia una auténtica conversión, si bien obtenida progresivamente, que será celebrada sacramentalmente. No se someten al sacramentalismo que midiera el éxito de una frecuencia restablecida del sacramento. «Frente a la crisis de la confesión individual, que cada vez se practica menos, y frente a la falta de sacerdotes, que es notoria, la Conferencia Episcopal Suiza ha decidido que se puedan celebrar penitencias comunitarias sacramentales. Para muchos fieles se ha abierto la vía de la conversión y del perdón, transmitido por la Iglesia. Los fieles experimentan la dimensión eclesial de la culpa y de la reconciliación ${ }^{372}$.

369. Card. J. ¿.. Bernardin y delegados del episcopado norteamericano, 171.

370. P. G. Ferrari, Superior General de los Misioneros Javieranos, 88.

371. Mons. R. Gay, Superior de los Misioneros de África, 123-124.

372. Mons. O. Wüst, obispo de Basilea (Suiza), 119-120; Mons. B: Blanchet, obispo de Gaspé (Canadá), 131: «Los obispos canadienses recomiendan dar pasos hacia adelante en el estudio de los fundamentos de la disciplina actual de la Iglesia sobre la confesión y absolución gene- 
2. Expresividad, lo más perfecta posible, de la naturaleza y efectos del sacramento ${ }^{373}$.

«La Iglesia debería adoptar, dentro de los propios límites de libertad de elección y de catolicidad, formas adecuadas de reconciliación sacramental. Puesto que la confesión auricular es típica de una sociedad individualista y personalista, la Iglesia no debería de excluir una forma más comunitaria» ${ }^{374}$, una forma más comprensible del acontecimiento reconciliación y penitencia», también «desde el punto de vista lingüístico y celebrativo» ${ }^{375}$.

\section{Ambos principios anteriores en estrecha relación con las realidades de las iglesias.}

«Dado el número insuficiente de sacerdotes en los países de misión, es necesario revisar la disciplina actualmente en vigor sobre las celebraciones comunitarias, de manera que pueda asegurarse a los penitentes - aun sin acusación individual, si es necesario- la seriedad de la confesión y de la reparación» ${ }^{376}$.

«Nuestros cristianos aman verdaderamente el sacramento de la penitencia. Sería exagerado hablar de una crisis propiamente dicha. Pero, en la situación socio-política actual, a veces la absolución general es el único medio posible de celebrar la penitencia. Los obispos han precisado las circunstancias en que se permite el uso de la absolución general. Pero desgraciadamente estas condiciones se han convertido en algo cada vez más frecuente y grave... En muchas situaciones lo que es extraordinario se ha convertido en ordinario y ni siquiera puede afirmarse que cambiará la situación...» ${ }^{377}$.

ral. Creen que esta cuestión debe ser estudiada en la perspectiva teológica más general de la Iglesia como sacramento de salvación (de reconciliación).

«El misterio de la reconciliación - misterio de la iniciativa reconciliadora de Dios y de la conversión recíproca que exige- se actúa a través del ministerio de la reconciliación, del que la Iglesia es simple servidora, particularmente a través del gesto sacramental de la penitencia.

«El sacramento es presentado en tres formas rituales específicas que podrían ser complementarias. La confesión y la absolución general evidencian el anuncio comunitario del primado del amor incondicionado de Dios.

«Estas consideraciones teológicas, entre otras, son lo suficientemente importantes como para justificar una profundización del tema».

373. Mons. L. Monsengwo Pasynia, obispo auxiliar de Kisangani (Zaire), 108-109.

374. Mons. A. Bongu Sinaga, obispo de Sibolga (Indonesia), 150-151.

375. P. E. Viganó, Superior Mayor de los Salesianos, 78.

376. Mons. L. Monsegwo Pasynia, obispo auxiliar de Kisangani (Zaire), 108-109.

377. Mons. M. F. da Costa, arzobispo de Huambo (Angola), 214-215. 
4. Los resultados positivos obtenidos en aquellos lugares en que se han llevado a la práctica las celebraciones comunitarias sacramentales.

«Frente a la actual crisis de la confesión individual, dado que la frecuencia disminuye y los sacerdotes escasean, la Conferencia Episcopal Suiza ha decidido, basada en el Ordo Poenitentiae, que se puedan celebrar penitencias comunitarias sacramentales con absolución general. Para muchos fieles ha significado el descubrimiento del camino de la conversión y del perdón transmitido por la Iglesia. También experimentan la dimensión eclesial del pecado y de la reconciliación» ${ }^{378}$.

«La experiencia del tercer rito ha sorprendido aun a los pastores más celosos y exigentes. Ha sido considerable la calidad de las celebraciones. $\mathrm{Mu}$ chos fieles hablan de una nueva experiencia de conversión y de una nueva conciencia de la Iglesia como comunidad reconciliadora. No han conducido al hundimiento de la confesión individual, sino que muchos sacerdotes constatan que a muchos los ha movido a frecuentar el primer rito» ${ }^{379}$.

\section{Efectiva ayuda al crecimiento de la conciencia personal del cristiano.}

Escribía el Card. Martini, en su relación del 10 octubre de 1984:

«La cuestión de la absolución general, prevista por el rito para casos de grave necesidad, ha centrado la atención de un elevado número de Padres, que se han hecho intérpretes de las diversas situaciones locales y de las diversas y complejas preocupaciones relacionadas con su práctica. Más allá de la determinación objetiva de las situaciones que configuran los casos de necesidad grave, está siempre la obligación de celebrar la penitencia comunitaria con la absolución general de tal manera que la convierta en una ayuda efectiva para el crecimiento de la conciencia personal del cristiano» ${ }^{380}$.

\section{Consecuencias}

1. Fomentar o, al menos, no obstaculizar una sana creatividad en el campo de las formas de reconciliacion.

El principio lo enuncia Mons. J.B. Möller, obispo de Groningen (Holanda):

«Es necesaria una investigación creativa de expresiones apropiadas de la reconciliación personal dentro de la realidad que vivimos» ${ }^{381}$.

378. Mons. O. Wüst, obispo de Basilea (Suiza), 119-120.

379. Mons. B. J. Wallace, obispo de Roeckhamptor (Australia), 156.

380. Card. C. M. Martini, 193.

381. Mons. B. Möller, obispo de Groningen (Holanda), 111. 
El Card. Papalardo, arzobispo de Palermo establece «la hipótesis y propone que le sea posible a la Iglesia instituir otras formas de celebración con carácter sacramental, no ligadas a la confesión de los pecados pero sí igualmente expresivas del arrepentimiento y del propósito de la enmienda». Estas formas se celebrarían cuando se tratara de «pecados de menor entidad», es decir, de pecados que no fueran «capitales». De estos pocados capitales, sostiene el cardenal, se debería de hacer una lista taxativa. Para ellos continuaría en vigor la disciplina actual...» ${ }^{382}$.

«Es preciso promover formas renovadas de celebrar este sacramento y escuchar a muchos que están al margen, como alejados de la vida cristiana».

«La vida penitencial de la Iglesia no ha sido lo suficientemente fecunda como para conducir a los pecadores a prácticas de perdón y de reconciliación, a lo largo de estapas y en lugares adecuados para re-encontrarse con Dios y con el prójimo.

«Sin abandonarnos a fantasías pastorales y siguiendo un orden sacramental coherente, debemos avanzar con la audacia de una sana creatividad. ¿No sería posible enriquecer el ritual con nuevas modalidades, que permitieran al conjunto de la Iglesia prácticas penitenciales acordes con su gran tradición, comprendiendo en ella también la anterior al Concilio de Trento?» ${ }^{383}$.

382. Card. S. Pappalardo, arzobispo de Palermo (Italia), 132.

383. Mons. G. Aubry, obispo de La Réunion, 157-158; Mons. A. Perraudin, arzobispo de Kabgayi (Rwanda), «Las intervenciones de los Padres sinodales africanos, acerca de la inculturación del sacramento de la penitencia deben ser tomadas en consideración. Es necesaria la introducción de nuevos elementos, para que su celebración sea mejor vivida por los africanos.

«Por supuesto que las innovaciones sobre el modo de celebrar la penitencia no deben ser improvisadas y que han de tener en cuenta la diversidad de culturas de la Iglesia de África.

1.- «Recordemos, ante todo, que la liturgia sacramental se basa en la Palabra de Dios, en los gestos de Cristo y de los apóstoles y no sobre una cultura humana, occidental o no. Es importante estudiar profundamente las innovaciones rituales en relación con los datos bíblicos y con la Tradición de la Iglesia, para no crear confusión en el espíritu y en el corazón de los fieles.

2.- Tampoco se puede olvidar que el continente africano es inmenso y muy diversificado. Los proyectos de adopción de modos de celebración deberán sopesar esta diversidad.

Sería equivocado pensar en una innovación única, válida para todo el continente. He aquí que las innovaciones litúrgicas deberían confiarse a la prudencia de las Conferencias episcopales, para que pudieran ser bien acogidas en cada País del Continente» (P. 182).

Mons. O. Wüst, obispo de Basilea (Suiza), 119-120: Teniendo en cuenta las experiencias positivas y la difícil situación pastoral, «los obispos suizos desean que las iglesias locales tengan la posibilidad de mostrarse plenamente como comunidades de Perdón. Consiguientemente la Iglesia universal no debería interpretar restrictivamente la forma de celebración comunitaria».

Mons. F. Favreau, obispo de Nanterre (Francia), 128: «El ritual de la penitencia se ha pensado en función de la confesión, cuando ésta es necesaria por los pecados. ¿No sería oportuno proponer una fórmula penitencial específicamente adaptada a las llamadas confesiones de devoción?». Y, quizás aludiendo a esa nueva fórmula, continúa: «En algunos lugares y en algunos grupos el acceso a la comunión se está vanalizando. ¿No sería necesario decir que algunas rupturas de la alianza y algunos escándalos públicos exigen, en conciencia, que el pecador recurra al sacramento de la penitencia antes de recibir la eucaristía? 
«La disminución de la confesión frecuente no ha de identificarse con una disminución del sentimiento de contrición. Una pastoral de la penitencia demasiado legalista del pasado ha limitado el carácter de la penitencia al sacramento. Es importante alargar el sentimiento de la contrición y favorecer la multiplicidad de las formas de penitencia» ${ }^{384}$.

\section{Reconocer plenamente el valor de las celebraciones comunitarias, y algu-} nos añaden, sin la obligación posterior de confesarse individualmente.

Es una consecuencia lógica de los presupuestos y de la creatividad indicados en páginas anteriores.

Algunos Padres lo proponen implícitamente:

«Si la Iglesia quiere seguir siendo signo e instrumento de reconciliación para muchos cristianos que no pueden celebrarla individualmente, importa subrayar el aspecto «eclesial de las celebraciones comunitarias que se practican desde hace algunos años sobre todo en estas iglesias (de misiones). En ellas los cristianos se abren en comunidad a la misericordia con Dios para reconciliarse con Él y con los hermanos... Cuando un sacerdote participa y preside tales celebraciones, puede darles la absolución general según el Ritual de 1973. Sin embargo la obligación de tener la intención de confesar las propias culpas graves «apenas posible» y personalmente, hace que los fieles que la reciben experimenten muchas dificultades en cuanto a la comprensión de la absolución general».

«Se desea que los Padres de este Sínodo reconsideren, por una parte, las necesidades pastorales de las comunidades cristianas numerosas y desprovistas de ministros de la reconciliación y por otra, reconozcan a las celebraciones comunitarias todo el valor sacramental y eclesial que encierran en sí» ${ }^{385}$.

Algunos otros Padres lo piden explícitamente: «Dada la insuficiencia de sacerdotes existentes en los países de misión, es necesario revisar la disciplina actualmente en vigor sobre las penitencias comunitarias de manera que asegu-

384. Mons. J. Wanke, administrador apostólico de Erfurt-Meiningen (Berlín), 88.

385. Mons. R. Gay, Superior General de los Misioneros de África, 123-124; Mons. J. Baatunde Adelakun, obispo de Oyo (Nigeria), 83; indica que esta iglesia elige otros caminos: «La gran cantidad de penitentes con pocos confesores plantea el problema siguiente: Los penitentes deben esperar durante horas antes de que les llegue el turno de la confesión; consiguientemente no se consigue prestar la atención debida a cada penitente y los sacerdotes, a veces, se ponen nerviosos y administran el sacramento de manera mecánica. Para resolver este problema los obispos han impartido las siguientes recomendaciones: Que se establezca un número mayor de días hábiles para la administración del sacramento; que haya frecuentes celebraciones no-sacramentales de la reconciliación; que se den frecuentes celebraciones sacramentales con confesión individual para grupos, invitando a los sacerdotes de las parroquias próximas...». 
re a los penitentes, también sin confesión individual si fuere necesario, la seriedad de la conversión y de la reparación» ${ }^{386}$.

Mucho más numerosas han sido las voces que pedían un uso más amplio de las penitencias comunitarias. "Es totalmente inadecuado afirmar que la causa de la escasa frecuencia del sacramento lo es la pérdida del sentido del pecado, puesto que tampoco lo frecuentan las personas piadosas, incluidos religiosos y clérigos. ¿Tal vez el Espíritu Santo invita a la Iglesia a un uso más frecuente del tercer rito, es decir, de la confesión general con absolución general?» ${ }^{387}$.

Es lamentable que se abuse de las celebraciones comunitarias cuando no se dan las condiciones necesarias, pero «¿Sería menos lamentable el que no se practiquen cuando se dan tales condiciones?» ${ }^{388}$.

«La experiencia cotidiana muestra la urgencia de que se encuentren nuevas formas pastorales de reconciliación y que se utilice, cuando se verifican las condiciones previstas, la forma de absolución general prevista por el Ordo, para ofrecer a todos la oportunidad de reconciliarse con Dios. En caso contrario la crisis y la desafección hacia el sacramento de la reconciliación se agravará» ${ }^{389}$.

«La reconciliación social y eclesial no deben separarse en la reconciliación que se da en el sacramento. Debemos dar vigor a la praxis de la confesión individual, pero, por otra parte, con las debidas cautelas, debemos hacer efectiva y ampliar por razones pastorales, la praxis de la absolución general» ${ }^{390}$.

\section{Rito penitencial de la misa.}

Dentro de la creatividad aludida algunos obispos hasta ultrapasan las tesis defendidas por la generalidad de los teólogos. Así el obispo Markus Frank Fernando, obispo de Chilaw (Sri Lanka) según el cual «se podría usar, al menos en ciertas ocasiones, un rito penitencial ampliado en la misa para dar la absolución general a quienes lo desearen sin necesidad de confesarse individualmente después».

«La creatividad podría indicar orientaciones y establecer salvaguardias. Se podrían establecer también gestos o posiciones particulares para aquellos que desearen recibir la absolución. También ésta es una forma de admisión de los propios pecados» ${ }^{391}$.

386. Mons. L. Monsengwo Pasynia, obispo auxiliar de Kisangani (Zaire), 108-109.

387. Mons. S. E. Carter, arzobispo de Kingston (Jamaica), 67.

388. Mons. S. E. Carter, 67.

389. P. G. Ferrari, Superior General de los Misioneros Javerianos, 88.

390. Mons. D. Castrillón Hoyo, obispo de Pereira (Colombia), 105.

391. Mons. M. F. Fernando, obispo de Chilaw (Sri Lanka), 111; Mons. M. Pérez-Gil González, (Méjico), 178: «No a la absolución general durante la misa. Invita al Sínodo a profundizar 


\section{Complementariedad.}

El grupo C de lengua inglesa concluye su trabajo «subrayando que el rito individual y el comunitario son complementarios entre sí y no debería de considerárseles contrapuestos». Consideramos que la celebración comunitaria, si no es usada de manera indiscriminada y habitual, no perjudica a la confesión individual ${ }^{392}$.

Parece que se da unanimidad en cuanto a la ampliación del principio de la complementariedad entre los valores que promueve cada una de las formas de celebración. Pero no ocurre lo mismo en cuanto a la interpretación del principio de la complementariedad.

Para algunos se trata de una complementariedad subordinada. El Card. Casoria, Prefecto de la Sagrada Congregación para los Sacramentos y el Culto «ha subrayado que la presencia de los tres ritos, en el Ordo Poenitentiae, no significa que puedan ser elegidos como al acaso, como ha precisado también el nuevo Derecho Canónico» ${ }^{393}$. «Las tres formas de celebración del sacramento de la penitencia no son situadas al mismo nivel por el Ordo Poenitentiae ni permite «una elección libre». La confesión personal es la forma ordinaria. La absolución general es forma extraordinaria prevista para casos de necesidad» ${ }^{394}$.

Para otros, en cambio, se trata de una complementariedad paritaria, diríamos. «se ayude de manera particular a los jóvenes para que vivan el sacramento de la reconciliación en las tres formas admitidas por el Nuevo Ritual de la Penitencia, sobre todo la segunda». Y Mons. Samuel E. Carter lo reafirma pero olvidándose de esa coletilla de «sobre todo la segunda»: «Cada uno de estos tres ritos tienen un valor propio distinto. Animemos a los fieles a usar los tres modos en su búsqueda de la reconciliación y de la penitencia» ${ }^{395}$.

La «Iglesia universal, como también la local, deben comprometerse a que tanto la confesión personal como la absolución general sean anunciadas y practicadas de modo adecuado, tanto desde el punto de vista humano como desde el teológico» ${ }^{396}$.

«Reconocemos la importancia del primer rito de la confesión como tam-

el tema tratado en el n. 33 del Instrumentum Laboris y sugiere que se suprima la costumbre impropia de dar la absolución general durante la celebración de la misa, puesto que, durante la celebración de la misa, se pueden celebrar otros sacramentos, pero no el de la confesión».

392. Mons. T. Worlock, relator del Grupo C de lengua inglesa, 197.

393. Card. G. Casoria, 149.

394. Card. J. Höffner, arzobispo-de Colonia (Alemania), 211.

395. Mons. R. Godinez Flores, obispo auxiliar de Guadalajara (Méjico), 107; Mons. S. E. Carter, 67.

396. Mons. P. Monjate, obispo de Tete (Monzambique), 148. 
bién la celebración comunitaria de la penitencia. Estamos en favor de un uso más extendido del tercer rito en algunas circunstancias, con tal de que vaya acompañado por una catequesis apropiada» ${ }^{397}$.

«Los obispos canadienses recomiendan la actuación de las tres formas sacramentales de reconciliación... Los obispos canadienses desean poder usar la forma comunitaria, con confesión y absolución general, como forma ordinaria en ocasiones especiales y en determinados períodos litúrgicos» ${ }^{398}$.

\section{Condiciones: Criterio prudencial sobre el uso de las comunitarias.}

En cuanto a las condiciones requeridas por el nuevo Ritual hasta los más cuidadosos y atentos a los problemas teológicos piden flexibilidad y amplitud en la interpretación de las mismas. El Card. G. Danneels sostiene que la actual disciplina encuentra justificación teológica en la tradición, en el concilio de Trento. Teme que las penitencias comunitarias pudieran conducir a la desaparición de la confesión individual y ciertamente deteriorarán la disciplina penitencial como ha ocurrido en las iglesias reformadas. No obstante todo esto afirma: «En conclusión, parece indicado atenerse a las condiciones prescritas por el nuevo Código, sin laxismo ni rigorismo» ${ }^{399}$. «La Iglesia universal no debería interpretar restrictivamente la forma de celebración comunitaria de la penitencia», dicen los obispos suizos ${ }^{400}$. Y algunos obispos de Angola se lamentan del rigorismo legislativo e interpretativo: «Nuestros cristianos aman verdaderamente el sacramento de la reconciliación... Pero en la actual situación socio-política a veces la absolución general es la única manera posible de celebrar la penitencia. Los obispos han especificado las circunstancias necesarias para el uso de la absolución general. Pero desafortunadamente estas condiciones cada vez se han hecho más numerosas y gravosas. Cuando nuestros cristianos reciben la absolución general, manifiestan claramente su tristeza por no poder celebrar la confesión individual. Lo que era extraordinario se ha convertido en ordinario en muchas ocasiones con el agravante de no saber si algún día cambiará la situación. Se trata de situaciones que pueden durar toda la vida. Yo mismo he dado la absolución general en poblados a los que después no llega ningún sacerdote...» ${ }^{401}$.

Para no caer ni en el laxismo ni en el rigorismo el grupo A de lengua española advierte: «Se ha de distinguir entre las exigencias doctrinales o dogmáti-

397. Mons. P. G. Cullinane, relator del Grupo A de lengua inglesa, 195.

398. Mons. M. A. J. Gervais, obispo auxiliar de London (Canadá), 122.

399. Card. G. Danneels, relator del Grupo A de lengua francesa, 205.

400. Mons. O. Wüst, obispo de Basilea (Suiza), 120.

401. Mons. M. F. da Costa, arzobispo de Huambo (Angola), 214-215. 
cas (la necesidad de confesarse individualmente «apenas posible») y las exigencias doctrinales. Si no se hiciera la debida distinción entre lo dogmático y lo disciplinar, se crearía una confusión que contribuiría, a veces, a la rigidez en aspectos susceptibles de una aplicación flexible y, a veces, al laxismo con el riesgo de negar la necesidad de confesar los pecados... ${ }^{402}$. Nos quedaremos con el principio en general sin entrar en la discusión de lo que en concreto consideran aquí dogmático o disciplinar. Sea lo que fuere de esto creo que no deberíamos olvidar que debemos «presentar el sacramento de la reconciliación con Dios como un don de Dios al hombre, sin aumentar la angustia del penitente insistiendo excesivamente en la confesión de los pecados según su número y especie. Se debería ampliar el uso de la absolución general como medio para re-conducir a los fieles a una plena aceptación del sacramento de la reconciliación» ${ }^{403}$.

Algunos sinodales, aunque tal vez no conscientemente, al menos desde el punto de vista científico-sistemático, parecen extender las condiciones legitimadoras más allá de las simples condiciones físicas, es decir, más allá de lo que sistemáticamente se llamaba imposibilidad física. Parecen admitir la fuerza legitimadora de la situación de aquellos que se sienten apartados del sacramento por la antipatía que sienten hacia la confesión individual por la forma de hacerla. La posibilidad de reconciliarse con Dios prima sobre las formas de manera que éstas deben evolucionar hasta abrir a todos la posibilidad y oportunidad de reconciliarse con Dios: «Si esto no se hace la crisis y desafección del sacramento se agravará» ${ }^{404}$.

Hermosísimo es a este respecto el siguiente párrafo de los obispo suizos: «La Iglesia, si quiere renovar su sistema penitencial y adaptarlo a las situaciones actuales, debe mirar a Cristo. Jesús se ha dirigido de modo especial a los pecadores como individuos y como pueblo. El hombre espera que la Iglesia se le muestre como comunidad de perdón, siguiendo el ejemplo de Cristo, sobre todo para con aquellos que no tienen la fuerza de dar el paso hacia la confesión individual, pero que se sitúan en la Iglesia tímidamente como el «publicano» con una genuina voluntad de conversión. Nuestra preocupación debe centrarse en la recuperación de la multiplicidad de formas presentes en la Escritura $\mathrm{y}$ practicadas en los primeros tiempos del cristianismo». Parece que esta es la interpretación que se ha de dar a este párrafo puesto que continuán: «Frente a la crisis de la confesión individual, dada la menor frecuencia y la falta de sacerdotes, la Conferencia Episcopal ha decidido, fundándose en el Ordo

402. Mons. D. Castrillón Hoyos, relator del Grupo A de lengua española, 198.

403. Mons. P. Verschuren, obispo de Helsinki (Finlandia), 80.

404. P. G. Ferrari, Superior General de los Misioneros Javieranos, 88. 
Poenitentiae, que se puedan celebrar penitencias comunitarias con absolución general. Muchos fieles han visto abierta así la vía del perdón y de la conversión y experimentan la dimensión eclesial de la culpa y de la reconciliación» ${ }^{405}$.

Mons. Ricardo Vidal, arzobispo de Cebú (Filipinas) lo afirma más explícitamente: «Parece que los impedimentos físicos y morales se han convertido en situación permanente en algunas tierras de misión y en muchas parroquias en las que existe una fuerte desproporción entre el número de fieles y el de sacerdotes...» ${ }^{406}$.

6. En concreto, creen que podrían celebrarse las penitencias comunitarias sacramentales en los siguientes casos:

\section{Con niños:}

«Prepárense cuidadosamente los niños para la confesión, de la que deben tener experiencia. No se trata en este caso de pecados graves, sino de una práctica motivada por razones pedagógicas y psicológicas» ${ }^{407}$.

\section{Cuando se tratara de confesiones de devoción:}

«El ritual de la penitencia se ha pensado en función de la confesión necesaria por los pecados graves. ¿No sería oportuno proponer una fórmula específicamente adaptada a las llamadas confesiones de devoción?» ${ }^{408}$.

\section{En los países de misión:}

«Un gran número de comunidades cristianas no pueden disfrutar de los beneficios de la confesión individual, por la simple razón de que no hay suficiente número de sacerdotes para asegurar este ministerio. En esta situación se encuentran muchas iglesias de África y de Filipinas.

«Si la Iglesia quiere seguir siendo signo e instrumento de reconciliación para estos cristianos, importa subrayar convenientemente el aspecto «eclesial» de las celebraciones comunitarias que se practican, desde hace algunos años, sobre todo en estas iglesias...» ${ }^{409}$.

405. Mons. O. Wüst, obispo de Basilea (Suiza), 119.

406. Mons. R. Vidal, obispo de Cebú (Filipinas), 166.

407. Card. J. Landázuri Ricketts, arzobispo de Lima (Perú), 75; Card. S. Oddi, 236, se muestra contrario: «En algunas diócesis perdura el abuso de admitir a los niños a la primera comunión sin previa confesión. No se trata solamente de la transgresión de una norma, sino también de un daño que se causa a la formación de la conciencia de los niños».

408. Mons. F. Favreau, obispo de Nanterre (Francia) 128.

409. Mons. R. Gay, Superior General de los Misioneros de África, 123-124; Mons. T. Worlock, relator del Grupo C de lengua inglesa, 199; Mons. L. Monsegwo Pasynia, obispo auxiliar de Kisangani (Zaire), 108-109; Mons. M. F. da Costa, obispo de Huambo (Angola), 214-216. 
«La necesidad de la celebración comunitaria sacramental es evidente en los países de misión» ${ }^{410}$.

\section{En las grandes parroquias con escasez de clero:}

«En las pequeñas diócesis y parroquias es muy fácil practicar la confesión individual. Pero se ha de reconocer que en las grandes parroquias, especialmente si se da insuficiencia de clero, existe un problema a la hora de escuchar las confesiones. El Sínodo debería afrontar este problema» ${ }^{411}$.

«Parece que los «impedimentos físicos y morales» se han convertido en situación permanente en algunas tierras de misión y en muchas parroquias en las que se da una fuerte desproporción entre el número de fieles y el de sacerdotes. ¿Cómo puede un solo sacerdote proveer a las necesidades sacramentales de parroquias de 20 ó 30 y, a veces, hasta de 50 ó 100 mil habitantes? Ayudaría mucho una perspectiva pastoral que valorara de manera más positiva los valores de la absolución general, al igual que sus límites y condiciones necesarias...» ${ }^{412}$.

\section{En la pastoral con los jóvenes:}

Mons. R. Gordinez Flores, preocupado por los jóvenes y por los pobres, a los que se debe dar prioridad en la evangelización, propone que «se ayude de manera particular a los jóvenes para que vivan el sacramento de la reconciliación en las tres formas admitidas por el Nuevo Ritual de la penitencia, sobre todo la segunda» ${ }^{413}$.

Y Mons. S.E. Carter extiende este pensamiento a todos los fieles: «Animemos a los fieles a usar los tres ritos en su búsqueda de la reconciliación y de la penitencia» ${ }^{414}$.

6. Como medio para reconducir a los fieles a una plena aceptación del sacramento:

«Teniendo presente la actual disminución de la frecuencia del sacramento de la reconciliación, se sugieren las siguientes perspectivas: subrayar el sentido de la presencia de Dios en la vida humana, proponer el sacramento de la reconciliación como don de Dios al hombre, sin aumentar la angustia del penitente insistiendo excesivamente en la confesión de los pecados según su especie y número. Como medio para reconducir a los fieles a la plena aceptación del

410. Mons. T. Worlock, relator del Grupo C de lengua inglesa, 199.

411. Mons. S. Kpcisko, arzobispo metropolita de Pittsburgh de rito bizantino, 144.

412. Mons. E. Vidal, arzobispo de Cebú (Filipinas), 166.

413. Mons. R. Godinez Flores, obispo auxiliar de Guadalajara (México), 107.

414. Mons. S. E. Carter, arzobispo de Kingston (Jamaica), 67. 
sacramento de la reconciliación; se debería extender el uso de la absolución general» ${ }^{415}$.

Dada esta situación "¿acaso el Espíritu invita a la Iglesia a un uso más frecuente del tercer rito, el de la confesión genérica y absolución general?» ${ }^{416}$.

7. Como que sugieren que se establezca un día mensual para tal celebración:

«Se sugiere que la Iglesia establezca un día al mes para una celebración comunitaria en las parroquias. Debería incluir el ayuno, la oración, la meditación y una homilía para que invitara a todos a la conversión y a la penitencia» ${ }^{417}$.

8. Ya hemos indicado anteriormente que algunos han querido revalorizar en este sentido el acto penitencial del inicio de la misa.

«Por lo que hace a la absolución general, se podría usar; al menos en ciertas ocasiones, un rito penitencial más amplio en la santa misa para dar la absolución general sacramental a los que lo desearen, sin necesidad de confesarse después individualmente.

«Podrían darse instrucciones apropiadas y establecer salvaguardias. Se podrían introducir gestos externos o posiciones particulares que deberían observar quienes desearan la absolución. También ésta es una forma de admisión de los pecados» ${ }^{418}$.

9. Algunos episcopados afirman tranquilamente que ya han dado los correspondientes permisos para la práctica de las penitencias comunitarias. Concretamente las Conferencias episcopales de Suiza y Australia, mientras que la. de Sudán lamenta que se le hayan abrogado las facultadés que Juan XXIII le había concedido de «usar el rito de la confesión general con absolución general, sin la obligación de confesar los pecados mortales en una confesión posterior» ${ }^{419}$.

415. Mons. P. Verschuren, obispo de Helsinki (Finlandia), 80.

416. Mons. S. E. Carter, 67.

417. Mons. F. K. Anani Lodonu, obispo de Keta-Ho (Gana), 141.

418. Mons. M. F. Fernando, obispo de Chilaw, Sri Lanka, 110-111.

419. Mons. B. J. Wallace, obispo de Rockhamptor (Australia), 156; Mons. O. Wüst, obispo de Basilea (Suiza), 119-120; Mons. G. Zubeir Wako, arzobispo de Khartoum (Sudán), 135. 
10. Comu que la confesión individual, pudiendo celebrarla cuando uno lo creyera conveniente, no sería obligatoria nada más que cuando se hubiera incurrido en pecados particularmente graves.

«Debe admitirse la división tripartita del pecado - venial, grave, mortal- porque parece que el Sínodo quiere dar nueva vitalidad a la absolución general como medio normal de perdonar los pecados» ${ }^{420}$.

«Se propone la hipótesis de que la Iglesia pueda establecer otras formas de celebración con carácter sacramental, para los pecados de menor entidad, no ligadas a la confesión de los pecados, pero que sean expresivas del arrepentimiento y del propósito de enmienda.

«Debería hacerse una lista taxativa de los pecados capitales, para los que seguiría en vigor la actual disciplina y hasta exigiéndose que la eventual reparación necesaria sea realizada antes de la absolución» ${ }^{421}$.

«Un segundo punto quisiera tomar én consideración: La naturaleza del pecado mortal en general. El pecado mortal es posible pero excepcional, según la S. Escritura y la Iglesia antigua. Es el cambio de opción fundamental del hombre contra Dios y contra el amor. Por ello debemos suponer que la mayoría de nuestros fieles, que frecuentan la misa, no ha cometido un pecado mortal. No obstante tienen necesidad de una conversión plena, sobre todo en lo relativo a los pecados sociales. También sus pecados veniales deben ser borrados. Dada esta situación ¿no sería deseable introducir nuevas formas de celebración del sacramento de la reconciliación, concluidas con la absolución general? Naturalmente que quedaría la obligación de confesar los pecados mortales y se les animaría a la confesión auricular de los pecados» ${ }^{422}$.

11. Parece que algún padre insinúa el establecimiento de alguna forma que permita practicar la reconciliación a aquellos que viven «al margen de la vida cristiana», aunque no nos ofrecen más precisiones.

La preocupación por estos casos, que pudiéramos llamar especiales, se ha manifestado en varias ocasiones en el Sínodo.

420. Mons. U. Cerasuolo Stacey, obispo auxiliar de Guayaquil (Ecuador), 128.

421. Card. S. Pappalardo, arzobispo de Palermo (Italia), 132.

422. Mons. S. F. Hamao, obispo de Yokohama (Japón), 170; Mons. F. Favreau, obispo de Nanterre (Francia), 128: «El acceso a la comunión se ha vanalizado en algunos sitios y entre algunos grupos. ¿No sería necesario acentuar que ciertas rupturas de la alianza y algunos escándalos públicos exigen en conciencia recurrir al sacramento de la penitencia antes de recibir la comunión?; Mons. J. de Jesús Pimiento Rodríguez, arzobispo de Manizales (Colombia), 94: «Parece llegado el momento de recuperar el valor originario penitencial, es decir, de conceder la reconciliación solo después de una severa y larga penitencia. Este sería el caso de ciertos pecados, cualificados como graves y definidos tales por la competente autoridad eclesial». 
«Sería necesario determinar si las parejas casadas no válidamente pueden acercarse oficialmente, en algunas ocasiones, a recibir el perdón y participar de la eucaristía» ${ }^{423}$.

\author{
Zacarías HERRERO
}

423. Mons. J. Wanke, administrador apostólico de Erfurt-Meiningen (Berlín), 89; Mons. $J$. Vilnet, obispo de Lielle (Francia), 76: «Después del Concilio se han renovado positivamente las celebraciones y la práctica de los sacramentos, pero el de la penitencia sufre la desafección de los fieles. Y, sin embargo, es necesario que tanto la comunidad creyente como cada fiel se nutran con la gracia de este sacramento, para que la Iglesia se deje reconciliar. Es necesario promover formas nuevas de practicar este sacramento y, al mismo tiempo, escuchar a muchos que viven en las fronteras de la vida cristiana»; Mons. O. Wüst, obispo de Basilea (Suiza), 119: «El hombre de hoy espera que la Iglesia se muestre como comunidad de perdón, que sigue el ejemplo de Cristo, sobre todo con aquellos que no se atreven a dar el paso a la confesión individual, que se sitúan en la Iglesia como con la timidez del «publicano», pero que, sin embargo, tienen una disposición genuina de conversión»; Mons. S. F. Hamao, obispo de Yokohama (Japón), 169-170: «Los divorciados re-casados son un grupo especialmente necesitado de reconciliación en el seno de la Iglesia. Esposos, abandonados sin su culpa, frecuentemente se encuentran en nuestra sociedad con la necesidad de contraer un nuevo matrimonio. Frecuentemente el segundo matrimonio tiene suceso, nacen hijos y así se crea una situación irreversible. Muchos de ellos se arrepienten de sus culpas y piden perdón y la admisión a la Eucaristía.

«Se les impone una difícil carga, cuando se les permite o manda asistir a la misa pero se les prohíbe la Eucaristía. La Iglesia mientras, por una parte mantiene firmemente la indisolubilidad del matrimonio, por otra debería demostrar misericordia y conceder el perdón a estas personas que viven en una situación de conflicto insanable. De esta manera la Iglesia aparecerá ante la humanidad como sacramento de reconciliación y de misericordia»; Mons. M. Maître, obispo de Bambari (Rep. Centroafricana), 188: «Tenemos planteado el problema de las situaciones matrimoniales irregulares. No se ve solución inmediata posible, pero lo sufren personas, conscientes de su pecado, que sufren y que querrían salir de ella sin poder hacerlo... Los pastores deberían tener la facultad de discernir a aquellas personas que tienen un verdadero deseo de conversión y no privarles de la misericordia del Señor que no ha venido para los sanos sino para los enfermos»; Mons. T. Tshibangu, relator del Grupo C de lengua francesa: «Se ha expresado respectuosamente el deseo de que, con ocasión del Año Santo, se abra el beneficio de la gracia del Jubileo a los fieles cristianos de todas las categorías que se encuentran en situaciones particulares»; Mons. L. Averkamp, relator del Grupo de lengua alemana: «La Iglesia debería dar orientaciones sobre el modo de comportarse con los divorciados re-casados, de manera que se les pudieran of recer elementos sabios y eficaces para su conversión. 